ALD2,2004-193

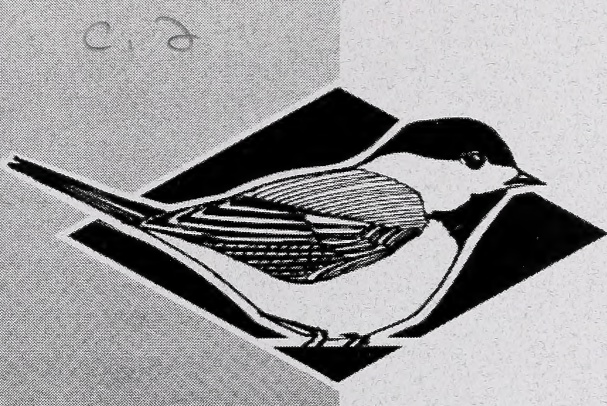

\title{
Survey of Aquatic Gastropods in the Central Parkland Subregion of Alberta
}

\section{Fish \& Whillie}

Division

RESOURCE DAMAND

SPEOIESAI RSK SEMIION

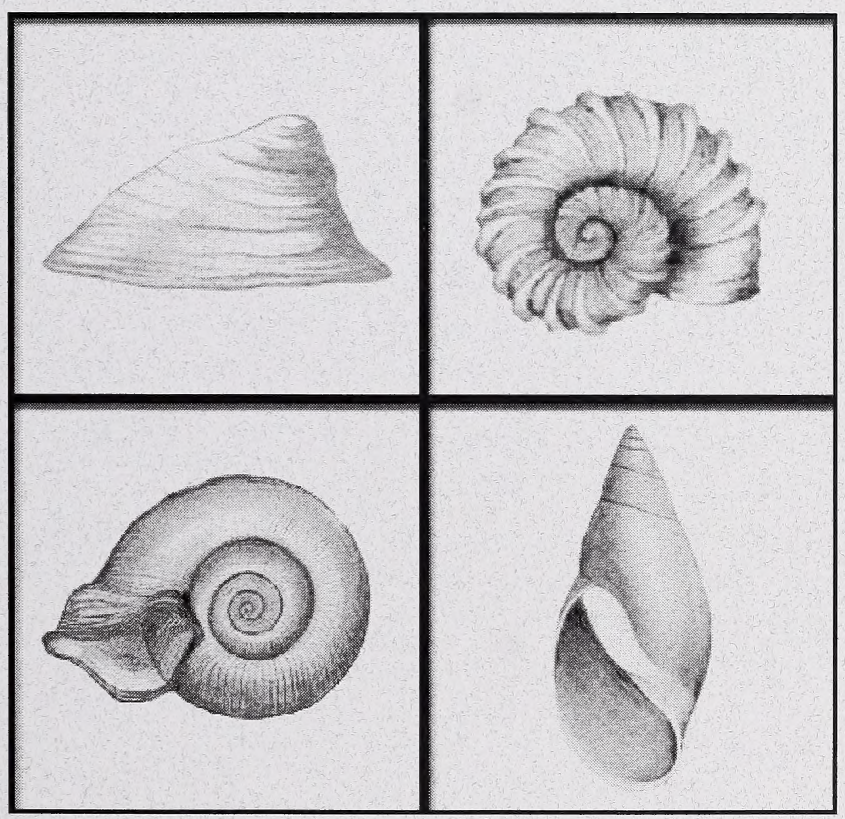

Alberta Species at Risk Report No. 92 
Digitized by the Internet Archive in 2016 


\section{Survey of Aquatic Gastropods in the Central Parkland Subregion of Alberta}

David R. C. Prescott and Medea M. Curteanu

Alberta Species at Risk Report No. 92

July 2004

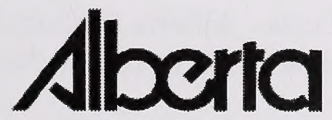

SUSTAINABLE RESOURCE

DEVELOPMENT 
Publication No.: I/187

ISBN: 0-7785-3618-1 (Printed Edition)

ISBN: 0-7785-3619-X (Online Edition)

ISSN: 1496-7219 (Printed Edition)

ISSN: 1496-7146 (Online Edition)

Cover Illustrations: Medea Curteanu

For copies of this report, contact:

Information Centre - Publications

Alberta Environment / Alberta Sustainable Resource Development

Main Floor, Great West Life Building

9920108 Street

Edmonton, Alberta, Canada T5K 2M4

Telephone: (780) 422-2079

\section{OR}

Visit our web site at:

http://www3.gov.ab.ca/srd/fw/riskspecies/

This publication may be cited as:

Prescott, D. R. C. and M. M. Curteanu. 2004. Survey of Aquatic Gastropods in the Central Parkland Subregion of Alberta. Alberta Sustainable Resource Development, Fish and Wildlife Division, Alberta Species at Risk Report No. 92, Edmonton, AB. 50 pp. 


\section{TABLE OF CONTENTS}

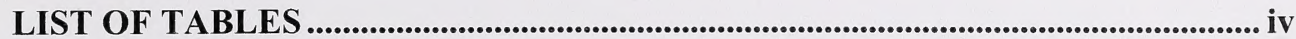

LIST OF FIGURES ........................................................................................... iv

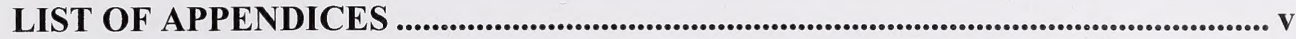

ACKNOWLEDGEMENTS .......................................................................................... vi

EXECUTIVE SUMMARY $\ldots . \ldots \ldots \ldots \ldots \ldots \ldots \ldots \ldots \ldots \ldots \ldots \ldots \ldots \ldots \ldots \ldots \ldots \ldots \ldots \ldots \ldots \ldots \ldots \ldots \ldots \ldots \ldots \ldots \ldots \ldots \ldots \ldots \ldots \ldots \ldots . . \ldots \ldots$ vii

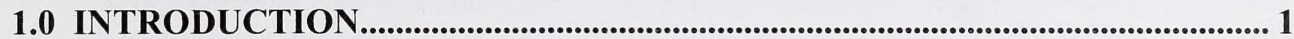

2.0 METHODS $\ldots \ldots \ldots \ldots \ldots \ldots \ldots \ldots \ldots \ldots \ldots \ldots \ldots \ldots \ldots \ldots \ldots \ldots \ldots \ldots \ldots \ldots \ldots \ldots \ldots \ldots \ldots \ldots \ldots \ldots \ldots \ldots \ldots \ldots \ldots \ldots \ldots \ldots \ldots \ldots \ldots \ldots \ldots . \ldots \ldots \ldots$

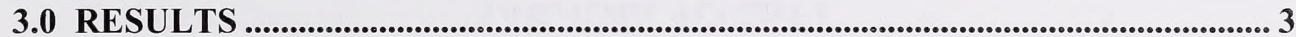

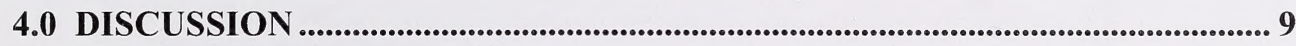

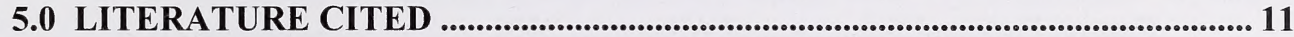




\section{LIST OF TABLES}

Table 1. Comparison of species/subspecies nomenclature used in this report (following Lepitzki 2001) versus that used in Turgeon et al. (1998) and Clarke (1981). Current risk status is from Lepitzki (2001)

Table 2. Summary of abundance and occurrence data for species (and identifiable subspecies) of aquatic gastropods in the Central Parkland Subregion of Alberta in 2001

Table 3. Species arranged in ascending order of mean $\mathrm{pH}(\mathrm{A})$ and conductivity (B). 8

\section{LIST OF FIGURES}

Figure 1. Location of 197 sites sampled during aquatic mollusc inventories in the Central Parkland Subregion of Alberta in 2001 


\section{LIST OF APPENDICES}

Appendix 1. Summary accounts for 32 species and subspecies of aquatic gastropods found during the 2001 inventory in Alberta's Central Parkland Subregion

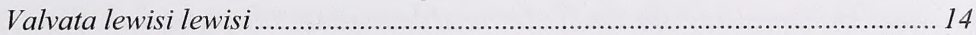

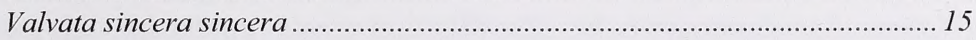

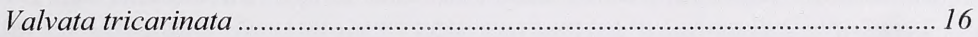

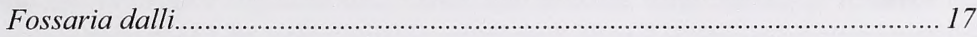

Fossaria galbana

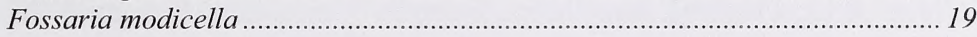

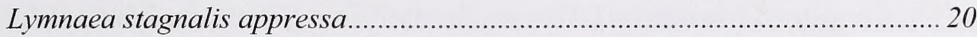

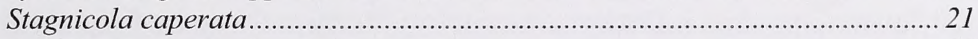

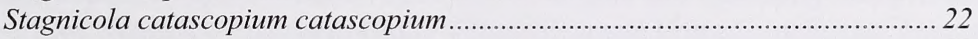

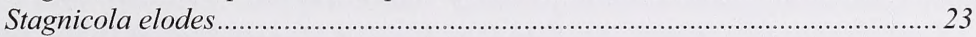

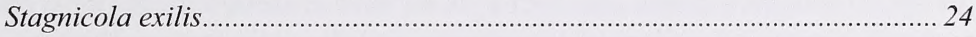

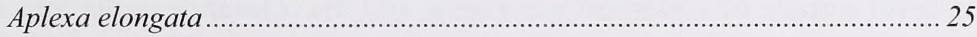

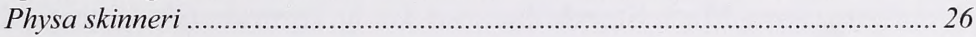

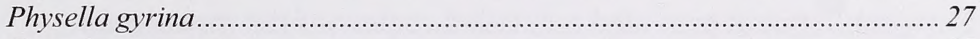

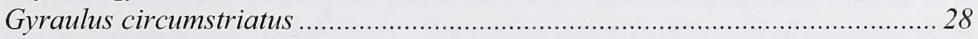

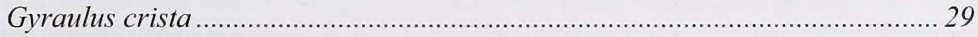

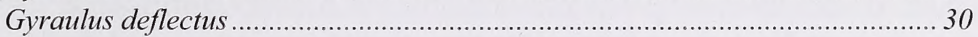

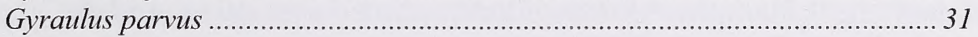

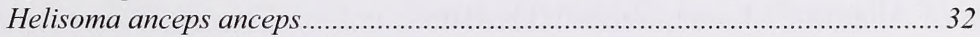

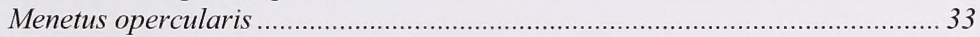

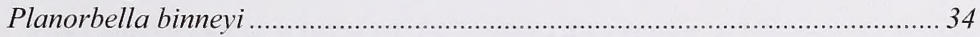

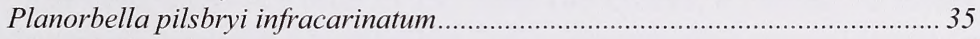

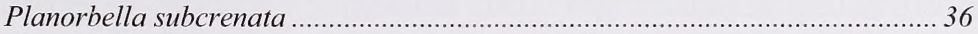

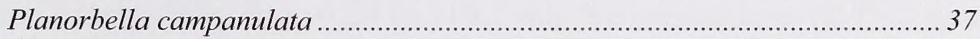

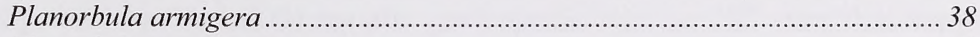

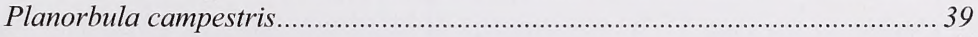

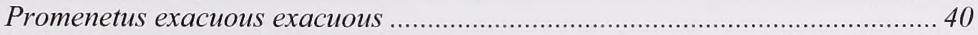

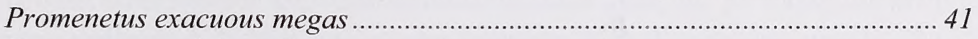

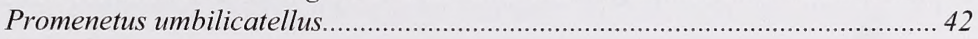

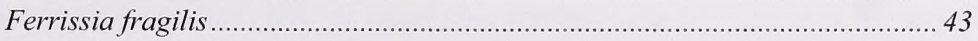

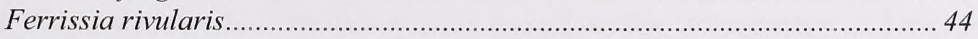

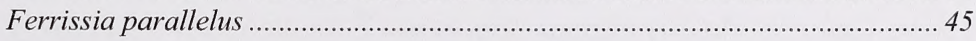

Appendix 2. Numbers of aquatic gastropods and characteristics of wetland collection sites in the Central Parkland Subregion of Alberta in 2001 


\section{ACKNOWLEDGEMENTS}

We thank the numerous individuals and agencies that participated in, or provided support for this study. For assistance with field collections, we thank Leslie Beattie, Brett Boukall, Dave Cheyne, Ken Froggatt, Paul MacMahon, Mark Piorecky, Eric Prescott, Ian Prescott, Cam Rowan, and Michelle Wells. Garry Scrimgeour (Alberta Research Council) and Vance Buchwald (Alberta Fisheries Management) provided some of the sampling equipment. Assistance with the identification of specimens through consultation and advice, the loan of specimens or access to collections was provided by Josef Ackerman (University of Guelph), Liath Appleton (University of Michigan), Robert T. Dillon, Jr. (College of Charleston), Jean-Marc Gagnon (Canadian Museum of Nature), Lane Graham (University of Manitoba), Gavin Hanke (The Manitoba Museum), Jacquie Lee (Ecological Specialists, Inc.), Dwayne Lepitzki (Wildlife Systems Research), Dale Parker (Aquatax Consulting), and Danny Shpeley (University of Alberta). For photography of specimens, we thank Heather Proctor and Danica Belter (University of Alberta). Long-term storage of collected specimens and the reference collection was provided by Bert Finnamore, Mark Steinhilber and Terry Thormin (Provincial Museum of Alberta). Dwayne Lepitzki provided a detailed review of the manuscript.

Financial support for this inventory was provided by the Alberta North American Waterfowl Management Plan, the Alberta Conservation Association, and the Species at Risk Program of Alberta Fish and Wildlife Division. 


\section{EXECUTIVE SUMMARY}

Despite their importance in wetland systems, few studies have focused on aquatic molluscs in Alberta. Our current understanding for many species is too limited to accurately determine their range, habitat requirements and biological status. Twenty-four $(30 \%)$ of 80 recognized species or subspecies of aquatic gastropods and bivalves are currently listed as being of "Undetermined" status in the province because of poor information (Clifford 2001, Lepitzki 2001). Of those that can be classified, almost half are deemed to be either "Sensitive", "May be at Risk" or "At Risk". Most authorities urge that current information be enhanced through extensive inventory efforts. In 2001, we conducted a detailed inventory of aquatic mollusks in the Central Parkland Subregion of central Alberta (representing approximately $8 \%$ of the province). Our ultimate goal was to clarify the biological risk of many species that are currently classified as being of "Undetermined" status in the province. This report deals only with the aquatic gastropods; analysis of bivalves will be reported at a future date.

To ensure representative sampling over a wide area, we collected samples from (when available) one creek, one river, one pond and one lake within each of the 1:50,000 map sheets that encompass the Subregion. Samples were collected primarily with hand nets and Eckman dredges. We recorded $\mathrm{pH}$ and conductivity with handheld meters at each site. Samples were later sorted and identified based on morphological characteristics, following nomenclature of Lepitkzi (2001) and Turgeon et al. (1998).

Sampling was conducted at a total of 197 sites ( 43 creeks, 67 lakes, 32 rivers and 55 ponds) between 14 July and 5 September 2001. Waterbodies ranged in $\mathrm{pH}$ from 6.0 to 10.7 , and in conductivity from 0.24 to $119.1 \mathrm{mS}$. Seventeen sites $(8.7 \%)$, generally alkali lakes and ponds, contained no aquatic gastropods. Of the 180 sites that supported aquatic gastropods, a total of 31,904 identifiable specimens of 32 species or subspecies were found. Valvata tricarinata was the most abundant species, in terms of both total numbers of specimens collected (9448) and mean number of individuals/sample (304.8). The most widely distributed species (live or dead specimens) was Gyraulus deflectus $(54.8 \%$ of sites). The most widely distributed species based on the occurrence of live specimens was Physella gyrina ( $25.4 \%$ of sites). Twenty-one species ( $65.6 \%$ of total) were found at less than 10 sites in the Central Parkland Subregion.

Species showed wide tolerances to water conditions. Taxa found alive at the highest values of $\mathrm{pH}$ (10.7) included Promenetus e. exacuous, Planorbella subcrenata, Lymnaea stagnalis appressa, Physa skinneri and Gyraulus circumstriatus. Physella gyrina was found to live over the greatest range of $\mathrm{pH}(6.0-10.2)$. Live specimens of all 32 species or subspecies were found at values of conductivity $<1.0 \mathrm{mS}$, but only six species were found alive in relatively alkali wetlands with conductivities $>6.0 \mathrm{mS}$. Valvata tricarinata was found to live at conductivities as high as $42.65 \mathrm{mS}$.

We identified one species, Planorbella campanulata, which has not previously been recorded in Alberta. The species was found at a single site approximately $10 \mathrm{~km}$ southwest of Edmonton. A single shell of Ferrissia fragilis (apparently the second record 
for Alberta) was retrieved from a site $15 \mathrm{~km}$ north of Edmonton. A notable range extension was observed for Planorbella pilsbryi infracarinatum, which was found at three sites in the Battle River system in the western half of the region. The species was previously known in Alberta only from Lac La Biche.

Based on information collected in this inventory, the current status of four species may require revision: Valvata tricarinata (currently listed as "Sensitive") was found to be widespread, abundant and tolerant of a broad range of water conditions; Aplexa elongata (currently "Secure") was sparsely distributed and of low abundance; Gyraulus crista (currently "Sensitive") was common and widespread; and Menetus opercularis (currently "May be at Risk") had a broad distribution and was locally abundant. Substantial new information was provided that will help clarify the status of many other species in the province. However, resolution of outstanding taxonomic issues and completion of inventories in other areas of Alberta will be necessary to accomplish this task. 


\subsection{INTRODUCTION}

One group of organisms that has been largely overlooked in Alberta is the aquatic molluscs (bivalves and gastropods). These animals are widely distributed and relatively common in a variety of lentic and lotic wetland types in the province. Molluscs are therefore important components of the aquatic systems and are important food for many aquatic, semi-aquatic and terrestrial organisms (Todd 1979, Pennak 1989, Brown 2001). They are also intermediate hosts of a variety of fish and waterfowl parasites (Brown 2001). In addition, many gastropods are filter feeders, and can concentrate toxic substances. This, along with their sensitivity to hydrological regimes (oxygen, nutrients, temperatures, etc.), make them excellent bio-indicators of environmental health in landscapes influenced by activities such as pulp mills, irrigation and hydroelectric dams, deforestation, and agriculture (Hart and Fuller 1974, Clarke 1981, Clifford 1991).

Despite their importance in wetland systems, few studies have focused on aquatic molluscs in Alberta. The most significant work to date has been the efforts of Clarke (1973), who spent parts of three field seasons between 1959 and 1969 collecting specimens in Alberta. The collections were made at 78 sites in the province, with a total of 6720 specimens being gathered. As a result of his work, we now know that there are approximately 28 species of bivalves and 50 species of aquatic gastropods in the province (the taxonomy of many closely related species is under debate). Many of these species are only known from a very few sites, which likely reflects both their patchy distributions and incomplete sampling effort. In any case, our current understanding for most species is too limited to accurately determine their range, habitat requirements and biological status. The uncertain status of many species was highlighted in a recent review of these taxa conducted for Alberta Sustainable Resource Development (Clifford 2001, Lepitzki $2001)$. They concluded that $24(30 \%)$ of 80 species of aquatic gastropods and bivalves were of "Undetermined" status because of poor information. Of those that could be classified, a relatively high proportion (46.4\%) were deemed to be either "Sensitive", "May be at Risk" or "At Risk" in the province. The single "At Risk" species, the Banff Springs Snail (Physella johnsoni), is also considered to be "Endangered" by the Committee on the Status of Endangered Wildlife in Canada (COSEWIC 2000). These syntheses and most other references that have assessed the status of aquatic molluscs (e.g. Clarke 1973, 1981), stress that current information on most species is weak, and must be enhanced through extensive and detailed inventory efforts.

Our main objective was to conduct a large-scale inventory of bivalves and aquatic gastropods in a wide variety of waterbodies in the Aspen Parkland of central Alberta. The work will be only the second effort to characterize aquatic mollusc populations over a large geographical area of Alberta, and will build on previous work by Clarke in the early 1960s. Our ultimate goal is to clarify the biological risk of many species that are currently classified as being of "Undetermined" status in the province. This will allow wetland managers to apply particular attention to species that are at high risk of extirpation in Alberta, that have unique or narrow habitat requirements, or that are highly sensitive to human activities. This report deals only with the aquatic gastropods. Analysis of bivalves collected during this study will be reported at a future date. 


\subsection{METHODS}

The Central Parkland Subregion, one of three subregions comprising the Aspen Parkland Natural Region in Alberta (see Achuff 1994 for description of Natural Regions and Subregions), is a transitional zone between the Grassland and Boreal Forest Natural Regions. The Central Parkland Subregion encompasses approximately 53,400 km (about $8 \%$ of Alberta), and is characterized by an interspersion of grasslands and trembling aspen (Populus tremuloides) groves, and a wide variety of permanent and ephemeral wetland types. The subregion supports the highest human population in Alberta. As a consequence, both upland and wetland habitats have been radically altered by human activities over the past 100 years (Alberta Environmental Protection 1997).

During the summer of 2001, we sampled aquatic molluscs across the entire Central Parkland Subregion. To ensure representative sampling from a variety of areas and wetland types, we attempted to sample one lake (generally a named, permanent wetland), one river (generally a named watercourse $>20 \mathrm{~m}$ in width at the point of sampling), one creek (often unnamed watercourse $<10 \mathrm{~m}$ in width), and one pond (usually an unnamed waterbody $<30$ ha in size) within each of the approximately 70, 1:50,000 map sheets that cover the subregion. We also attempted to sample one alkali wetland in each mapsheet in the eastern half of the subregion. Sample sites were chosen primarily for their accessibility by road, and presence of suitable launch sites for boats, when necessary.

A variety of sampling techniques were used at each site, depending on wetland size, water depth, substrate type, and complexity of emergent vegetation and other habitats (for general discussion of sampling techniques see Clarke 1981 or Dillon in press). These techniques included: 1) use of an Eckman dredge in deeper waters ( $>1.5 \mathrm{~m})$ or off bridges, 2) sweeping with hand-nets off lake and river bottoms, and 3) sweeping with hand-nets through emergent vegetation, and (4) hand-picking of larger shells along shorelines. Small boats were used to access larger or deeper wetlands, whereas smaller or shallow areas were sampled using chest or hip-waders. Sampling continued until it was deemed a representative sample of molluscs had been collected (generally $<30$ minutes). At each site, we recorded $\mathrm{pH}$ and conductivity $(\mathrm{mS})$ using handheld meters, and recorded the location with handheld GPS units. Notes were recorded on the particular sampling techniques used at each site. Preliminary cleaning of samples was done on site to remove large debris so that samples could be stored in 500 or $1000 \mathrm{ml}$ jars containing $70 \%$ ethanol. All sampling equipment was rinsed before proceeding to the next site, in order to prevent cross-contamination of samples. Upon return to the laboratory, samples were cleaned and placed in smaller sample vials. In some cases, samples contained a large number $(>500)$ of specimens. These samples (approximately $25 \%$ of collection sites) were usually split into smaller subsamples (generally $50 \%$ ) for final cleaning and analysis. In all cleaned samples, bivalves were removed and stored separately in ethanol for future analysis.

Like many large and poorly studied taxa, the classification of aquatic gastropods is the source of considerable debate (Burch 1989). Because our work was primarily an attempt to clarify the status of species evaluated by Lepitzki (2001), we adopted the nomenclature 
therein. His nomenclature closely follows that of Turgeon et al. (1998), which is the most widely used reference for common and scientific names of molluscs in North America. However, Lepitzki (2001) refers to several subspecies that are not recognized by Turgeon et al. (1998). These subspecies are also recognized in the current study. A list of names used by Lepitzki (2001) and this study, are compared with those of Turgeon et al. (1998) and Clarke (1981) in Table 1.

To aid in identification, a dichotomous key (available from the authors) was developed, based primarily on morphological descriptions of Clarke (1981). Other guides, such as Burch (1989) were also consulted, as were specimens of known identity obtained from various museums and universities (see Acknowledgements). We also developed a reference collection of the taxa we encountered. Reference specimens, along with all collected samples, are archived in the Provincial Museum of Alberta for future reference. A representative specimen of each taxon in the reference collection was photographed (see Appendix 1) through a Leica MZ16 dissecting microscope, using a Canon S40 digital camera, fibre optic lighting, and Remote Capture software for Macintosh.

Specimens were identified to the species (and occasionally subspecies) level based on morphological characteristics. Examination was facilitated with a dissecting microscope. Calipers were used to measure shells when required for identification. The number of individuals of each species or recognized subspecies in each sample was tallied.

Juveniles were included in counts when positive identification was possible. We also noted whether at least one shell of each species or subspecies contained fleshy tissue, indicating that live specimens were present in the local population. If samples had previously been split into smaller units for counting (see above), an appropriate correction factor was used to determine the total number of individuals of each taxon present. We subsequently classified the species as being "rare" (1 individual), "uncommon" (2-10 individuals), "common" (11-100 individuals), or "abundant" (>100 individuals) in each sample.

Data for each species were compiled into a one-page summary that included a photograph, a map showing sites where the species was found, a summary of abundance, distribution and habitat characteristics where the species was collected, and a textual synthesis of information relative to the species' status in the region (see Appendix 1).

\subsection{RESULTS}

Sampling was conducted at a total of 197 sites in the Central Parkland Subregion (Figure 1, Appendix 2) between 14 July and 5 September 2001. A small number (13) of sites were outside of the recognized boundaries of the subregion. Ten of these were in the Boreal Forest Natural Region (Dry Mixedwood Subregion), whereas three were in the Grassland Natural Region (Northern Fescue Subregion). All but one of these sites was within $10 \mathrm{~km}$ of the Central Parkland Subregion. The exception was Wabamum Lake, which was approximately $30 \mathrm{~km}$ west of the Subregion boundary. All 13 sites were situated in "parkland-like" habitats, and are included in the study as being representative 
Table 1. Comparison of species/subspecies nomenclature used in this report (following Lepitzki 2001) versus that used in Turgeon et al. (1998) and Clarke (1981). Current risk status is from Lepitzki (2001).

\begin{tabular}{|c|c|c|c|}
\hline This Study/Lepitzki 2001 & Turgeon et al. 1998 & Clarke 1981 & Current Status \\
\hline Valvata lewisi lewisi & Valvata lewisi & Valvata sincera sincera & Sensitive \\
\hline Valvata sincera sincera & Valvata sincera & Valvata sincera helicoidea & Sensitive \\
\hline Valvata tricarinata & Valvata tricarinata & Valvata tricarinata & Sensitive \\
\hline Fossaria dalli & Fossaria dalli & Bakerilymnaea dalli & Sensitive \\
\hline Fossaria galbana & Fossaria galbana & Fossaria decampi & Sensitive \\
\hline Fossaria modicella & Fossaria modicella & Fossaria modicella & Secure \\
\hline Lymnaea stagnalis appressa & Lymnaea stagnalis & Lymnaea stagnalis jugularis & Secure \\
\hline Stagnicola caperata & Stagnicola caperatus & Stagnicola caperata & Secure \\
\hline $\begin{array}{c}\text { Stagnicola catascopium } \\
\text { catascopium }\end{array}$ & Stagnicola catascopium & $\begin{array}{c}\text { Stagnicola catascopium } \\
\text { catascopium }\end{array}$ & Undetermined \\
\hline Stagnicola elodes & Stagnicola elodes & Stagnicola elodes & Secure \\
\hline Stagnicola exilis & Stagnicola exilis & Stagnicola reflexa & Undetermined \\
\hline Aplexa elongata & Aplexa elongata & Aplexa hypnorum & Secure \\
\hline Physa skinneri & Physa skinneri & Physa jennessi skinneri & Undetermined \\
\hline Physella gyrina & Physella gyrina & Physa gyrina gyrina & Secure \\
\hline Gyraulus circumstriatus & Gyraulus circumstriatus & Gyraulus circumstriatus & Secure \\
\hline Gyraulus crista & Gyraulus crista & Armiger crista & Sensitive \\
\hline Gyraulus deflectus & Gyraulus deflectus & Gyraulus deflectus & Secure \\
\hline Gyraulus parvus & Gyraulus parvus & Gyraulus parvus & Secure \\
\hline Helisoma anceps anceps & Helisoma anceps & Helisoma anceps anceps & Sensitive \\
\hline Menetus opercularis & Menetus opercularis & Menetus cooperi & May be at Risk \\
\hline Planorbella binneyi & Planorbella binneyi & Helisoma trivolvis binneyi & Undetermined \\
\hline $\begin{array}{c}\text { Planorbella pilsbryi } \\
\text { infracarinatum }\end{array}$ & Planorbella pilsbryi & $\begin{array}{l}\text { Helisoma pilsbryi } \\
\text { infracarinatum }\end{array}$ & Undetermined \\
\hline Planorbella subcrenata & Planorbella trivolvis (in part) & $\begin{array}{c}\text { Helisoma trivolvis } \\
\text { subcrenatum }\end{array}$ & Secure \\
\hline Planorbella campanulata ${ }^{a}$ & Planorbella campanulata & $\begin{array}{l}\text { Helisoma campanulatum } \\
\text { campanulatum }\end{array}$ & Not Assessed \\
\hline Planorbula armigera & Planorbella armigera & Planorbula armigera & Sensitive \\
\hline Planorbula campestris & Planorbella campestris & Planorbula campestris & Sensitive \\
\hline Promenetus exacuous exacuous & Promenetus exacuous (in part) & $\begin{array}{c}\text { Promenetus exacuous } \\
\text { exacuous }\end{array}$ & Secure \\
\hline Promenetus exacuous megas & Promenetus exacuous (in part) & Promenetus exacuous megas & Sensitive \\
\hline Promenetus umbilicatellus & Promenetus umbilicatellus & Promenetus umbilicatellus & Sensitive \\
\hline Ferrissia fragilis & Ferrissia fragilis & Ferrissia fragilis & Undetermined \\
\hline Ferrissia rivularis & Ferrissia rivularis & Ferrissia rivularis & Undetermined \\
\hline Ferrissia parallelus & Ferrissia parallela & Ferrissia parallela & Undetermined \\
\hline
\end{tabular}

${ }^{a}$ not listed by Lepitzki (2001), so name from Turgeon et al. (1998) used. 


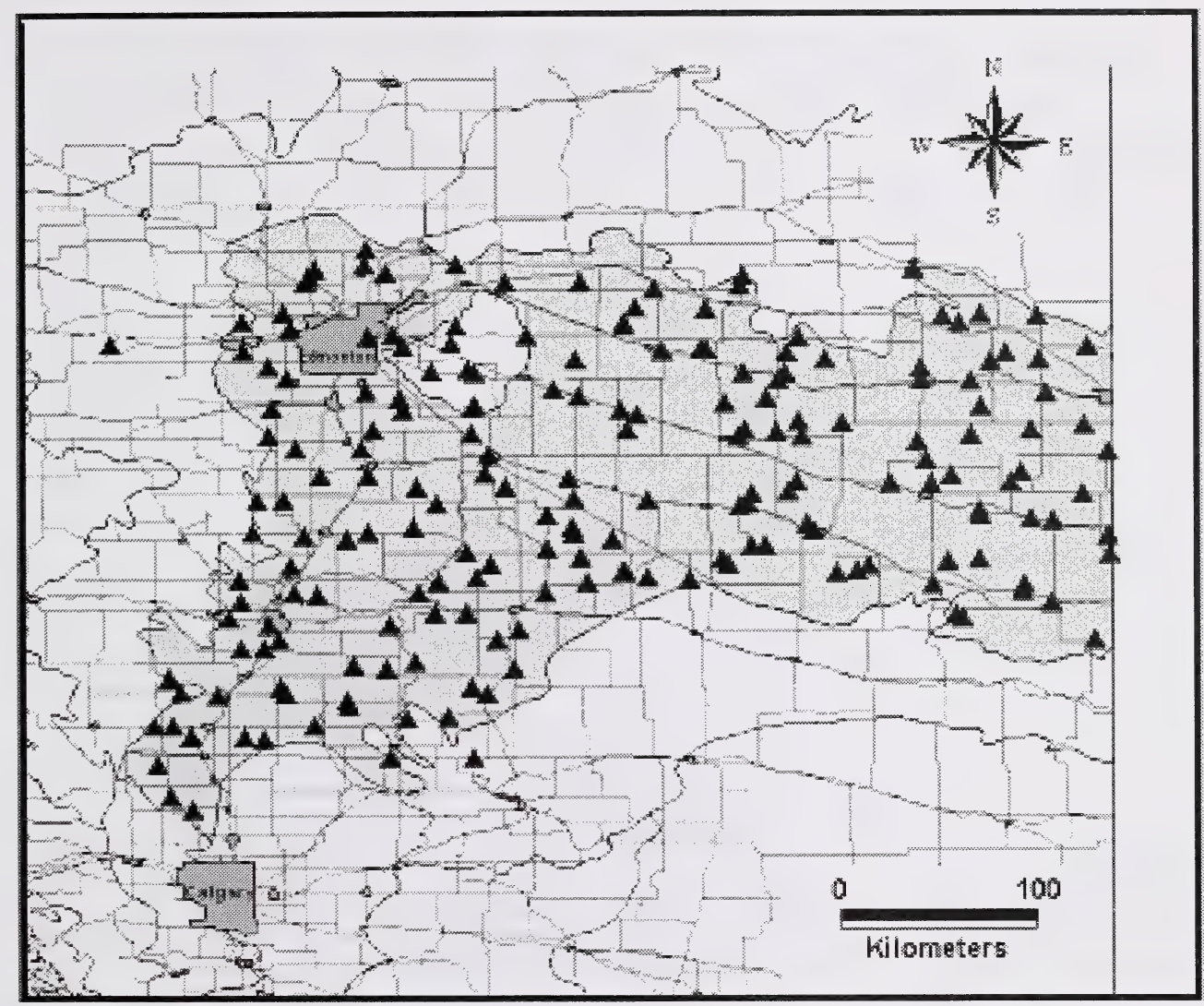

Figure 1. Location of 197 sites sampled during aquatic mollusc inventories in the Central Parkland Subregion of Alberta in 2001.

of the area. Sites included 43 creeks ( $21.8 \%$ of total), 67 lakes $(34.0 \%), 32$ rivers $(16.3 \%)$ and 55 ponds $(27.9 \%)$. These waterbodies ranged in $\mathrm{pH}$ from 6.0 to 10.7 $(\mathrm{mean}=8.8 \pm 0.1[\mathrm{SE}])$, and in conductivity from 0.24 to $119.1 \mathrm{mS}($ mean $=3.66 \pm 0.77)$.

Seventeen sites $(8.7 \%)$ contained no aquatic gastropods. Fourteen of these sites were alkali lakes or ponds, which tended to have higher $\mathrm{pH}(9.32 \mathrm{vs} .8 .73 ; \mathrm{T}=1.65, \mathrm{df}=194$, $\mathrm{p}<0.01)$ and higher conductivity $(20.17$ vs. $2.20 \mathrm{mS} ; \mathrm{T}=7.1, \mathrm{df}=194, \mathrm{p}<0.0001)$ than sites where specimens were present. Terrestrial species (total of 378 individuals, usually empty shells) were found at 64 sites, including one of the sites where no aquatic species were found. Succinea $s p$. was the most commonly encountered terrestrial species (194 individuals at 43 sites).

Of the 180 sites that supported aquatic gastropods, a total of 31,904 identifiable specimens of 32 species or subspecies were found (Table 2). Valvata tricarinata was the most abundant species, in terms of both total numbers of specimens collected (9448) and 
mean number of individuals/sample (304.8), although it ranked only $11^{\text {th }}$ in terms of number of sites occupied. The most widely distributed species (live or dead specimens) was Gyraulus deflectus, which was found at $54.8 \%$ of sites, although the percentage of sites occupied by live specimens ranked $6^{\text {th }}(14.7 \%)$. The most widely distributed species determined by the presence of live specimens was Physella gyrina ( $25.4 \%$ of sites). Twenty-one species $(65.6 \%$ of total) were found at less than 10 sites in the Central Parkland Subregion (Table 2).

Individual species showed great differences in the mean and range of water $\mathrm{pH}$ and conductivity where live specimens were found (Table 3). However, caution must be expressed in inferring that these ranges represent "tolerances", as the number of sites where live specimens occurred was undoubtedly underrepresented, the ranges of water conditions in the region may be smaller than some species could tolerate (especially for $\mathrm{pH}$, where only one site had $\mathrm{pH}<7.0$ ), and because sample sizes for many species were small. Species found alive at the highest $\mathrm{pH}$ values recorded in the study site (10.7) were Promenetus e. exacuous, Planorbella subcrenata, Lymnaea stagnalis appressa, Physa skinneri and Gyraulus circumstriatus. The species found living over the greatest range of $\mathrm{pH}$ was Physella gyrina (6.0-10.2). Other species found over a wide $\mathrm{pH}$ range $(>3.5$ units) include Gyraulus deflectus (6.0-9.9), Stagnicola elodes (6.0-9.8), Planorbella subcrenata and Lymnaea stagnalis appressa (both 7.0-10.7). Live specimens of all 32 species or subspecies were found at values of conductivity $<1.0 \mathrm{mS}$, but only six species were found alive in relatively alkali wetlands with conductivities $>6.0 \mathrm{mS}$. Most notable was Valvata tricarinata, which was found to live at conductivities as high as $42.65 \mathrm{mS}$. Other species found in these alkali wetlands were Stagnicola elodes (maximum conductivity $16.11 \mathrm{mS})$, Physa skinneri $(8.78 \mathrm{mS})$, Planorbella subcrenata $(8.65 \mathrm{mS})$, Menetus opercularis and Gyraulus deflectus (both $6.50 \mathrm{mS}$ ).

The inventory of the Central Parkland Subregion yielded several notable records. We identified one species, Planorbella campanulata, which has not previously been recorded in Alberta. The species was found at a single site (17 specimens, including live individuals) in an unnamed pond approximately $10 \mathrm{~km}$ southwest of Edmonton. $P$. campanulata is known to be common across eastern North America as far west as central Saskatchewan, and may also occur in the lower Fraser River of British Columbia (Clarke 1981; referred to as Helisoma campanulatum campanulatum). A single empty shell of Ferrissia fragilis was retrieved from an unnamed pond approximately $15 \mathrm{~km}$ north of Edmonton. Clarke (1981) describes this species as being "common" in still-water habitats in southwestern British Columbia and in southern Ontario and Quebec, and as being "widely distributed" in the United States. This record is apparently the second for Alberta, with the only previous record occurring in the Mariana Lakes in northeastern Alberta (Lepitzki 2001). A notable range extension was observed for Planorbella pilsbryi infracarinatum, which was found at three sites in the Battle River system in the western half of the region. The species was previously known in Alberta only from Lac La Biche (Clarke 1973, Lepitzki 2001). 
Table 2. Summary of abundance and occurrence data for species (and identifiable subspecies) of aquatic gastropods in the Central Parkland Subregion of Alberta in 2001. Total number of specimens, and mean \#/sample are for all specimens retrieved (live or dead), whereas the percentage of sites where found are separated for all specimens, and for sites where only live specimens were found. Numbers in parentheses are ranks.

\begin{tabular}{|c|c|c|c|c|}
\hline Species/Subspecies & $\begin{array}{c}\text { Total \# } \\
\text { individuals }\end{array}$ & $\begin{array}{c}\% \text { sites found } \\
\text { (all individuals) }\end{array}$ & $\begin{array}{c}\% \text { sites found } \\
\text { (at least one live } \\
\text { individual) }\end{array}$ & $\begin{array}{c}\text { Mean \#/sample } \\
\text { (all) }\end{array}$ \\
\hline Valvata lewisi lewisi & $25(20)$ & $2.0(22)$ & $2.0(13)$ & $6.3(20)$ \\
\hline Valvata sincera sincera & $461(13)$ & $6.1(15)$ & $1.5(15)$ & $38.4(3)$ \\
\hline Valvata tricarinata & $9448(1)$ & $15.7(11)$ & $8.6(8)$ & $304.8(1)$ \\
\hline Fossaria dalli & $73(16)$ & $9.6(12)$ & $1.5(15)$ & $3.8(24)$ \\
\hline Fossaria galbana & $199(14)$ & $3.6(17)$ & $2.5(12)$ & $28.4(6)$ \\
\hline Fossaria modicella & $9(26)$ & $1.0(26)$ & $0.0(28)$ & $4.5(22)$ \\
\hline Lymnaea stagnalis appressa & $1109(11)$ & $35.5(6)$ & $22.3(2)$ & $15.8(14)$ \\
\hline Stagnicola caperata & $127(15)$ & $7.1(14)$ & $1.5(15)$ & $9.1(18)$ \\
\hline Stagnicola catascopium catascopium & $16(23)$ & $0.5(29)$ & $0.5(21)$ & $16.0(13)$ \\
\hline Stagnicola elodes & $1914(5)$ & $45.2(4)$ & $20.8(5)$ & $21.5(11)$ \\
\hline Stagnicola exilis & $23(21)$ & $2.5(18)$ & $0.5(21)$ & $4.6(21)$ \\
\hline Aplexa elongata & $33(18)$ & $5.6(16)$ & $0.5(21)$ & $3.0(25)$ \\
\hline Physa skinneri & $1400(6)$ & $47.2(2)$ & $22.3(2)$ & $15.1(15)$ \\
\hline Physella gyrina & $2152(4)$ & $37.6(5)$ & $25.4(1)$ & $29.1(5)$ \\
\hline Gyraulus circumstriatus & $1160(10)$ & $23.4(9)$ & $11.2(7)$ & $25.2(9)$ \\
\hline Gyraulus crista & $1303(7)$ & $30.0(8)$ & $7.6(9)$ & $22.1(10)$ \\
\hline Gyraulus deflectus & $3598(3)$ & $54.8(1)$ & $14.7(6)$ & $33.3(4)$ \\
\hline Gyraulus parvus & $5693(2)$ & $34.0(7)$ & $2.0(13)$ & $85.0(2)$ \\
\hline Helisoma anceps anceps & $66(17)$ & $2.5(18)$ & $1.0(18)$ & $13.2(17)$ \\
\hline Menetus opercularis & $484(12)$ & $9.1(13)$ & $3.6(11)$ & $26.9(8)$ \\
\hline Planorbella binneyi & $5(28)$ & $1.0(26)$ & $0.0(28)$ & $2.5(28)$ \\
\hline Planorbella pilsbryi infracarinatum & $12(25)$ & $1.5(24)$ & $0.5(21)$ & $4.0(23)$ \\
\hline Planorbella subcrenata & $1247(9)$ & $47.2(2)$ & $22.3(2)$ & $13.4(16)$ \\
\hline Planorbella campanulata & $17(22)$ & $0.5(29)$ & $0.5(21)$ & $17.0(12)$ \\
\hline Planorbula armigera & $3(30)$ & $1.0(26)$ & $0.0(28)$ & $1.5(30)$ \\
\hline Planorbula campestris & $8(27)$ & $2.5(18)$ & $0.5(21)$ & $1.6(29)$ \\
\hline Promenetus exacuous exacuous & $1269(8)$ & $22.8(10)$ & $6.6(10)$ & $28.2(7)$ \\
\hline Promenetus exacuous megas & $29(19)$ & $2.0(22)$ & $1.0(18)$ & $7.3(19)$ \\
\hline Promenetus umbilicatellus & $4(29)$ & $1.5(24)$ & $1.0(18)$ & $1.3(31)$ \\
\hline Ferrissia fragilis & $1(32)$ & $0.5(29)$ & $0.0(28)$ & $1.0(32)$ \\
\hline Ferrissia rivularis & $13(24)$ & $2.5(18)$ & $0.5(21)$ & $2.6(27)$ \\
\hline Ferrissia parallelus & $3(30)$ & $0.5(29)$ & $0.0(28)$ & $3.0(25)$ \\
\hline
\end{tabular}


Table 3. Species arranged in ascending order of mean $\mathrm{pH}(\mathrm{A})$ and conductivity (B).

Means were only calculated for sites where live specimens were found (sample size in parentheses beside species name). Five species are omitted (Fossaria modicella, Planorbella binneyi, Planorbula armigera, Ferrissia fragilis and Ferrissia parallelus) as no live specimens were found at any sites.

\section{A. $\mathrm{pH}$}

\begin{tabular}{|c|c|}
\hline Species/Subspecies & $\begin{array}{c}\text { Mean pH } \\
\text { (range) }\end{array}$ \\
\hline Promenetus umbilicatellus (2) & $7.6(7.4-7.8)$ \\
\hline Planorbula campestris (1) & 7.7 \\
\hline Promenetus exacuous megas (2) & $7.7(7.5-7.8)$ \\
\hline Aplexa elongata (1) & 7.8 \\
\hline Fossaria galbana (5) & $8.1(6.0-9.3)$ \\
\hline Valvata lewisi lewisi (4) & $8.1(7.7-8.6)$ \\
\hline Planorbella campanulata (1) & 8.1 \\
\hline Promenetus e. exacuous (13) & $8.5(7.5-10.7)$ \\
\hline Stagnicola elodes (41) & $8.5(6.0-9.8)$ \\
\hline Gyraulus deflectus (29) & $8.6(6.0-9.9)$ \\
\hline Planorbella subcrenata (44) & $8.6(7.0-10.7)$ \\
\hline Gyraulus crista (15) & $8.7(7.7-9.5)$ \\
\hline Physella gyrina $(50)$ & $8.7(6.0-10.2)$ \\
\hline Valvata sincera sincera (3) & $8.7(8.1-9.1)$ \\
\hline Lymnaea stagnalis appressa (44) & $8.8(7.0-10.7)$ \\
\hline Fossaria dalli (3) & $8.8(7.8-9.5)$ \\
\hline Menetus opercularis (7) & $8.8(7.8-9.5)$ \\
\hline Physa skinneri (44) & $8.9(7.4-10.7)$ \\
\hline Gyraulus parvus (4) & $8.9(7.7-9.5)$ \\
\hline Helisoma anceps anceps (2) & $8.9(8.6-9.2)$ \\
\hline Stagnicola caperata (3) & $8.9(8.0-9.5)$ \\
\hline Stagnicola c. catascopium (1) & 9.0 \\
\hline Gyraulus circumstriatus (22) & $9.1(7.8-10.7)$ \\
\hline Valvata tricarinata $(17)$ & $9.1(8.1-10.0)$ \\
\hline Stagnicola exilis (1) & 9.2 \\
\hline Ferrissia rivularis (1) & 9.3 \\
\hline Planorbella pilsbryi infracarinatum (1) & 9.9 \\
\hline
\end{tabular}

\section{B. Conductivity (mS)}

\begin{tabular}{|c|c|}
\hline Species/Subspecies & $\begin{array}{l}\text { Mean conductivity } \\
\text { (range) }\end{array}$ \\
\hline Ferrissia rivularis (1) & 0.30 \\
\hline Helisoma anceps anceps (2) & $0.33(0.24-0.41)$ \\
\hline Stagnicola c. catascopium (1) & 0.34 \\
\hline Valvata sincera sincera $(3)$ & $0.41(0.35-0.45)$ \\
\hline Planorbella campanulata (1) & 0.43 \\
\hline Valvata lewisi lewisi (4) & $0.44(0.31-0.57)$ \\
\hline Stagnicola exilis (1) & 0.46 \\
\hline Gyraulus parvus (4) & $0.48(0.24-0.77)$ \\
\hline Physella gyrina (50) & $0.62(0.24-2.50)$ \\
\hline Fossaria dalli (3) & $0.64(0.50-0.82)$ \\
\hline Planorbella pilsbryi infracarinatum (1) & 0.64 \\
\hline Planorbula campestris (1) & 0.66 \\
\hline Aplexa elongata $(1)$ & 0.82 \\
\hline Promenetus e. exacuous (13) & $0.93(0.47-1.45)$ \\
\hline Fossaria galbana (5) & $1.01(0.30-3.65)$ \\
\hline Lymnaea stagnalis appressa (44) & $1.04(0.29-3.65)$ \\
\hline Promenetus exacuous megas (5) & $1.06(0.82-1.30)$ \\
\hline Stagnicola caperata (3) & $1.18(0.59-1.68)$ \\
\hline Promenetus umbilicatellus (2) & $1.22(0.82-1.62)$ \\
\hline Gyraulus circumstriatus (22) & $1.28(0.29-4.29)$ \\
\hline Planorbella subcrenata (44) & $1.33(0.31-8.65)$ \\
\hline Gyraulus crista (15) & $1.34(0.45-3.01)$ \\
\hline Menetus opercularis (7) & $1.55(0.45-6.50)$ \\
\hline Gyraulus deflectus (29) & $1.58(0.24-6.50)$ \\
\hline Stagnicola elodes (41) & $1.93(0.30-16.11)$ \\
\hline Physa skinneri (44) & $2.05(0.33-8.78)$ \\
\hline Valvata tricarinata (17) & $3.15(0.29-42.65)$ \\
\hline
\end{tabular}


Summary accounts for each of the 32 species or subspecies found during the survey are found in Appendix 1. Information on each of the 197 collection sites, including numbers of each species/subspecies collected, is provided in Appendix 2.

\subsection{DISCUSSION}

The majority of species listed by Lepitzki (2001) as occurring in central Alberta were found during this study. Several species that were not detected include four species of Fossaria ( $F$. bulimoides, $F$. parva, $F$. rustica and $F$. obrussa) that are of uncertain taxonomy, and may not represent valid species (Burch 1989, Lepitzki 2001). The ranges of two additional species, Stagnicola traski and Physa jennessi are largely outside of the Central Parkland, although their presence in our study area cannot be ruled out. Physa megalochlamys, a recently defined species in western North America (Taylor 1988), is very similar to P. skinneri, and no attempt was made to separate the two species in this study (all were considered to be $P$. skinneri). However, $P$. megalochlamys is believed to occur in southern Saskatchewan and Alberta, and possibly throughout British Columbia (Taylor 1988, Lee 2000, Lepitzki 2001). It is therefore probable that some of our specimens of $P$. skinneri may actually be of $P$. megalochlamys. One specimen of Probythinella emarginata was found in a sample that was collected before organized sampling for this study began. Location data was not recorded (it was likely from the eastern part of the region), and the specimen was eventually lost. The species is therefore present, but apparently very rare in central Alberta. P. emarginata has been reported from several sites in Alberta (Lepitzki 2001).

Our primary intent in this inventory was to better define the distribution and population size of aquatic gastropods in central Alberta, and thereby help clarify the risk status of species in the province. For many species, such clarification is difficult to achieve, because the taxonomy and identification are unclear (e.g. Fossaria spp., Stagnicola spp., Planorbella spp.), because the generalized sampling technique we used underestimated occurrence and abundance (e.g. Ferrissia spp.), or because the distribution and abundance in central Alberta may not be reflective of the rest of the province. Nevertheless, the Central Parkland Subregion supports the vast majority of species found in the province as a whole, so the status of species in this region has significant bearing on the provincial status for many taxa. Given this, the following species may be candidates for a revision of status in the future (see Appendix 1 for more detailed discussion of individual species and Lepitzki 2001 for derivation of current status ranks):

(1) Valvata tricarinata: Currently listed as "Sensitive", but found in this study to be widespread, often abundant, and with wide tolerance to water conditions

(2) Aplexa elongata: Currently listed as "Secure", but found to be sparsely distributed and of low abundance

(3) Gyraulus crista: Currently listed as "Sensitive", but found to be common and widespread

(4) Menetus opercularis: Currently listed as "May be at Risk", but found to have a broad distribution and to be locally abundant. 
(5) Planorbella campanulata, a new species for the province that was found during this inventory, will need to be considered for assignment of an appropriate status.

Our inventory is probably the most intensive conducted to date in the province, but covered only a single Natural Subregion, which encompasses a small proportion $(8 \%)$ of the provincial land base. It is clear that much more study of aquatic gastropods is necessary in Alberta, and we hope that our work will prompt similar efforts in other parts of the province. Such surveys will be necessary to clarify the status of a number of species, and if repeated, will provide data required for detecting temporal and spatial changes in distribution resulting from human activities. Given the poor information for many aquatic gastropods, any future studies will contribute greatly to our knowledge of the ecology, status, and ultimately the conservation of this valuable aquatic resource. 


\subsection{LITERATURE CITED}

Achuff, P. L. 1994. Natural regions, subregions and natural history themes of Alberta. Alberta Environmental Protection, Parks Service, Edmonton, AB. 72 pp.

Alberta Environmental Protection. 1997. The Parkland Natural Region of Alberta. Natural Resources Service, Recreation and Protected Areas Division, Edmonton, AB. 111 pp.

Brown, K. M. 2001. Mollusca: Gastopoda. Pp. 297-329 in Ecology and classification of North American freshwater invertebrates (J. H. Thorp and A. P. Covich, eds.). Academic Press, New York. 950 pp.

Burch, J. B. 1989. North American freshwater snails. Malacological Publications, Hamburg, MI. 365 pp.

Clampitt, P. T. 1970. Comparative ecology of the snails Physa gyrina and Physa integra (Basommatophora: Physidae). Malacologia 10:113-151.

Clarke, A. H. 1973. The freshwater molluscs of the Canadian Interior Basin. Malacologia 13: 1509.

Clarke, A. H. 1981. The freshwater mollusks of Canada. National Museum of Natural Sciences, Ottawa, ON. $446 \mathrm{pp}$.

Clifford, H. F. 1991. Aquatic invertebrates of Alberta. University of Alberta Press, Edmonton, AB. $538 \mathrm{pp}$.

Clifford, H. F. 2001. Bivalves: 2000 preliminary status ranks for Alberta. Alberta Sustainable Resource Development, Fish and Wildlife Division, Edmonton, AB. 42 pp.

COSEWIC. 2000. Canadian species at risk. Committee on the Status of Endangered Wildlife in Canada, Ottawa, ON. 19 pp.

Dillon, R. T., Jr. In Press. How to study and collect freshwater gastropods. $\underline{I n}$ : How to study and collect molluscs (C. F. Sturm, ed.). American Malacological Society. Available at: http://www.cofc.edu/\%7Edillonr/Dillon_FW_Gast_Chptr.pdf.

Emerson, W. K., and M. K. Jacobson. 1976. Guide to shells, land, freshwater and marine, from Nova Scotia to Florida. A. A. Knopf, New York, NY. 482 pp.

Hart, C. W., Jr., and S. L. H. Fuller (eds.). 1974. Pollution ecology of freshwater invertebrates. Academic Press, New York, NY. 389 pp.

Lee, J. S. 2000. Freshwater molluscs of British Columbia. Assessments for all known or potential taxa. Final report prepared for Conservation Data Center, Ministry of Environment, Lands and Parks, Victoria, BC. 107 pp. 
Lepitzki, D. A. W. 2001. Gastropods: 2000 preliminary status ranks for Alberta. Alberta Sustainable Resource Development, Fish and Wildlife Division, Edmonton, AB. 126 pp.

Pennak, R. W. 1989. Fresh-water invertebrates of the United States. Protozoa to Mollusca. $3^{\text {rd }}$ ed. John Wiley and Sons, New York, NY. 656 pp.

Pip, E. 2000. The decline of freshwater molluscs in southern Manitoba. Can. Field-Natur. 114: 555-560.

Taylor, D. W. 1988. New species of Physa (Gastropoda: Hygrophila) from the western United States. Malacological Review 21:43-79.

Todd, F. S. 1979. Waterfowl. Sea World Press, San Diego, CA. 399 pp.

Turgeon, D. D., J. F. Quinn, Jr., A. E. Bogan, E. V. Coan, F. G. Hochberg, W. G. Lyons, P. M. Mikkelsen, R. J. Neves, C. F. E. Roper, G. Rosenberg, B. Roth, A. Scheltema, F. G. Thompson, M. Vecchione, and J. D. Williams. 1998. Common and scientific names of aquatic invertebrates from the United States and Canada: mollusks, 2nd edition. American Fisheries Society, Special Publication 26, Bethesda, MD. 526 pp. 
Appendix 1. Summary accounts for 32 species and subspecies of aquatic gastropods found during the 2001 inventory in Alberta's Central Parkland Subregion. See text for complete description of nomenclature, status, and sampling methodology. Refer to Clarke (1981) and Burch (1989) for definitions and descriptions of morphological terms.

\section{Notes to "Characteristics" section of Appendix 1:}

(1) Wetland use is presented as raw percentages, along with percent difference in use relative to availability (in parentheses). Difference in use is based on creeks, lakes, rivers and ponds representing $21.8 \%, 34.0 \%, 16.3 \%$, and $27.9 \%$ of sites sampled, respectively (see text).

(2) Mean \#/sample is based on all individuals (alive or dead), for sites where species or subspecies was found.

(3) Abundance classes are: "Rare" (1 individual), "Uncommon" (2-10 individuals), "Common" (11-100 individuals), and "Abundant" (>100 individuals), and include both live and dead specimens in a sample. 


\section{Valvata lewisi lewisi}

Fringed valvata

\section{Current Status: Sensitive}

Valvata lewisi lewisi is similar to $V$. sincera sincera in having a small depressed shell, dextral coiling and moderately elevated spire (Clarke 1981; where V. I. lewisi is referred to as Valvata sincera sincera, and $V$. s. sincera is referred to as $V$. lewisi helicoidea [see Burch 1989]). As well, the operculum, which is characteristic of live specimens of this genus, is round, horny and multispiral (Clarke 1981). V. I. lewisi can be differentiated by the lower spire and the presence of conspicuous surface lamellae or fine blade-like ridges present in fresh specimens (Clarke 1981).

V. I. lewisi has a broad distribution across North America, from Newfoundland to British Columbia and north to the Yukon Territory. The range extends south in the United States to Maine and Minnesota (Clarke 1981). The subspecies is believed to intergrade with $V$. s. sincera where their ranges overlap (Clarke 1981). V. I. lewisi is most commonly found in lakes, often at considerable depths, as well as on mud among submerged vegetation (Clarke 1981). In British Columbia, the subspecies is common throughout the province and is listed as "secure" (Lee 2000). In Alberta, V. I. lewisi has been found at a variety of locations in all natural regions except the Canadian Shield (Lepitzki 2001). It appears to be absent from west-central parts of the province (Clarke 1981, Lepitzki 2001).

Surveys in the Central Parkland Subregion found $V$. I. lewisi to have a localized distribution. The subspecies was collected from $4(2.0 \%)$ sites, all in the northwestern corner of the Subregion to the west and southwest of Edmonton. At the locations where it was found, the subspecies was most often observed to be "rare" ( 1 individual), with a maximum of 20 individuals being retrieved from a site. Living specimens were found at all sites. These sites spanned a relatively narrow range of $\mathrm{pH}$ (7.7 to 8.6) and conductivity ( 0.31 to $0.57 \mathrm{mS}$ ).

Valvata lewisi lewisi has a limited distribution in the Central Parkland Subregion, and, where it occurs, is uncommon and lives in a fairly narrow range of water conditions. 


\section{Valvata sincera sincera}

Mossy valvata

\section{Current Status: Sensitive}

Valvata sincera sincera is identified by its small depressed shell, dextral coiling and moderately elevated spire (Clarke 1981; referred to as Valvata sincera helicoidea). The operculum, present in live specimens, is round, horny, and multispiral. In comparison to $\mathrm{V}$. lewisi lewisi, adult shells of $\mathrm{V}$. s. sincera are larger, lack surface lamellae and have finer, more crowded collabral lines (Clarke 1981). There has been some confusion regarding the identification and nomenclature of $V$. s. sincera and V. I. lewisi in the literature (Burch 1989, Lee 2000, Lepitzki 2001).

V. s. sincera is described as an arctic and subarctic species, occurring from Alaska to Labrador and south to James Bay. A more southerly, disjunct population is reported to cover a broad area of westcentral Alberta (Clarke 1981). V. s. sincera lives among aquatic vegetation in a variety of habitats such as lakes, ponds, slow-moving streams and rivers, and muskeg pools (Clarke 1981). In British Columbia, the species, when identified according to Burch (1989), is common throughout the province and is listed as "secure" (Lee 2000). In Alberta, the species has been found at several locations in all natural regions except the Grasslands (Lepitzki 2001).

Surveys in the Central Parkland Subregion suggest a broad, although sparse, distribution. V. s. sincera was collected from $12(6.1 \%)$ sites sampled, mostly in the western parts of the region. It occurred in a variety of habitats, but was most typically found in rivers and lakes. At the locations where it was found, the species was most often observed to be "uncommon" or "common" (2-100 individuals). However, the species was occasionally found to be "abundant" with a maximum of 169 individuals being retrieved from a site. Living specimens were found over a moderate $\mathrm{pH}$ range of 8.1 to 9.1 , and over a relatively narrow range of conductivities $(0.35$ to 0.45 $\mathrm{mS})$.

Valvata sincera sincera has a limited distribution, is rarely abundant, and occurs over a fairly narrow range of water conditions in Alberta's Central Parkland Subregion.
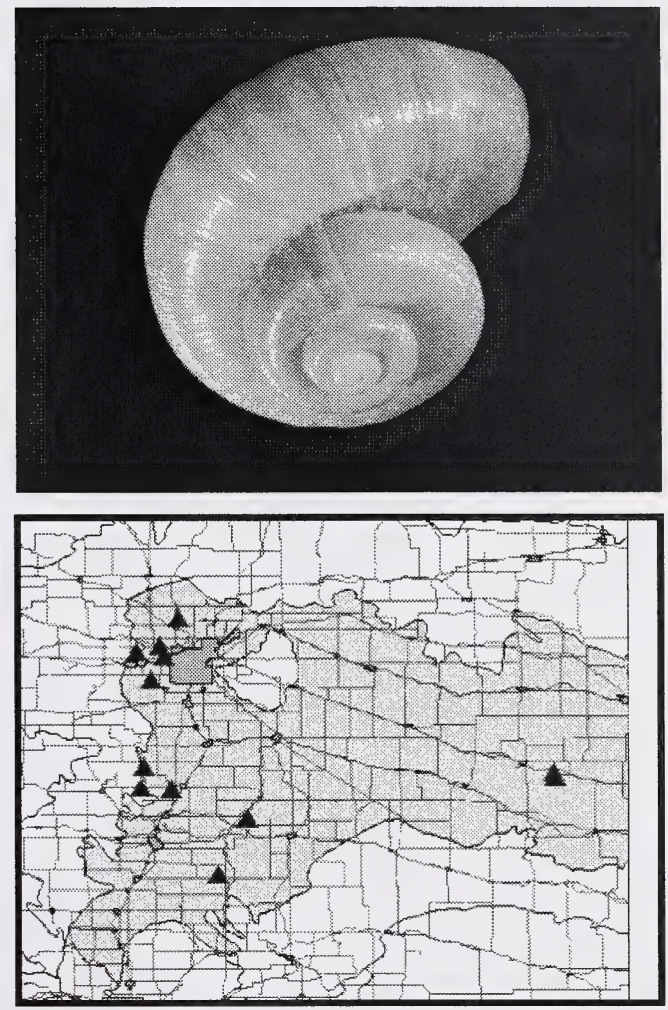

\section{Characteristics}

Present at $12(6.1 \%)$ of 197 sites Alive at $3(1.5 \%)$ of 197 sites

\begin{tabular}{ccc}
\multicolumn{3}{c}{ Wetland Use: } \\
\hline Type & $\begin{array}{c}\% \text { of occupied } \\
\text { sites }\end{array}$ & $\begin{array}{c}\text { Relative to } \\
\text { availability }\end{array}$ \\
\hline River & $25.0 \%$ & $+53.4 \%$ \\
Lake & $41.7 \%$ & $+22.6 \%$ \\
Creek & $8.3 \%$ & $-61.9 \%$ \\
Pond & $25.0 \%$ & $-10.4 \%$ \\
\hline
\end{tabular}

\section{Abundance:}

Mean \#/sample: 38.4 (range: 1-169)

Rare: $16.7 \%$

Uncommon: $25.0 \%$

Common: $50.0 \%$ Abundant: $8.3 \%$

\section{Water Chemistry:}

\section{All Sites}

Mean $\mathrm{pH}: \overline{8.5 \text { (range: } 7.9-9.1 \text { ) }}$

Mean conductivity: $0.54 \mathrm{mS}$ (range: $0.29-0.98$ )

\section{Sites With Live Specimens}

Mean pH: 8.7 (range: 8.1-9.1)

Mean conductivity: $0.41 \mathrm{mS}$ (range: $0.35-0.45$ ) 


\section{Valvata tricarinata}

Threeridge valvata

\section{Current Status: Sensitive}

Valvata tricarinata is easily identified by the unique presence of three prominent carinae, or spiral ridges, around a flattened body whorl (Clarke 1981). Adult shells are small, solid and depressed, generally reaching a height of $5 \mathrm{~mm}$. The operculum, which is present in live specimens, is round, horny, and multispiral (Clarke 1981). The shell is generally green and translucent, although brownish individuals may also be encountered.

$V$. tricarinata has a broad distribution across North America. The range extends from New Brunswick to eastern British Columbia and the Northwest Territories up to the tree line, and south to Virginia, lowa and Nebraska (Clarke 1981). The species lives in vegetated, perennial waterbodies such as lakes, rivers, streams and muskeg pools, and occasionally in ponds (Clarke 1981). In British Columbia, the species has been found at only one location and is listed as being of "historical occurrence" (Lee 2000). In Alberta, $V$. tricarinata has been previously found in all natural regions, but is apparently absent from the southwestern corner of the province (Lepitzki 2001).

Surveys in the Central Parkland Subregion indicate that this species is of widespread distribution, and can reach high abundances. $V$. tricarinata was found at $31(15.7 \%)$ sites, with a strong bias towards occurring in larger rivers and lakes. At locations where it was found, $V$. tricarinata was most often described as being "common" or "abundant" (>10 individuals). In addition, the species had the highest average abundance (304.8 specimens/sample) and the greatest total number of specimens observed (9448) of all the species identified in this study (Table 2). Living specimens were found over a $\mathrm{pH}$ range of 8.1 to 10.0 , and at conductivities of 0.29 to $42.65 \mathrm{mS}$. The species was far more tolerant of alkali conditions (i.e., high conductivity) than any other species in central Alberta (Table 3).

Valvata tricarinata has a widespread distribution, is often abundant, and has a wide tolerance to water conditions in Alberta's Central Parkland Subregion. The current status of "Sensitive" (Lepitzki 2001) may require revision to a lower risk category.
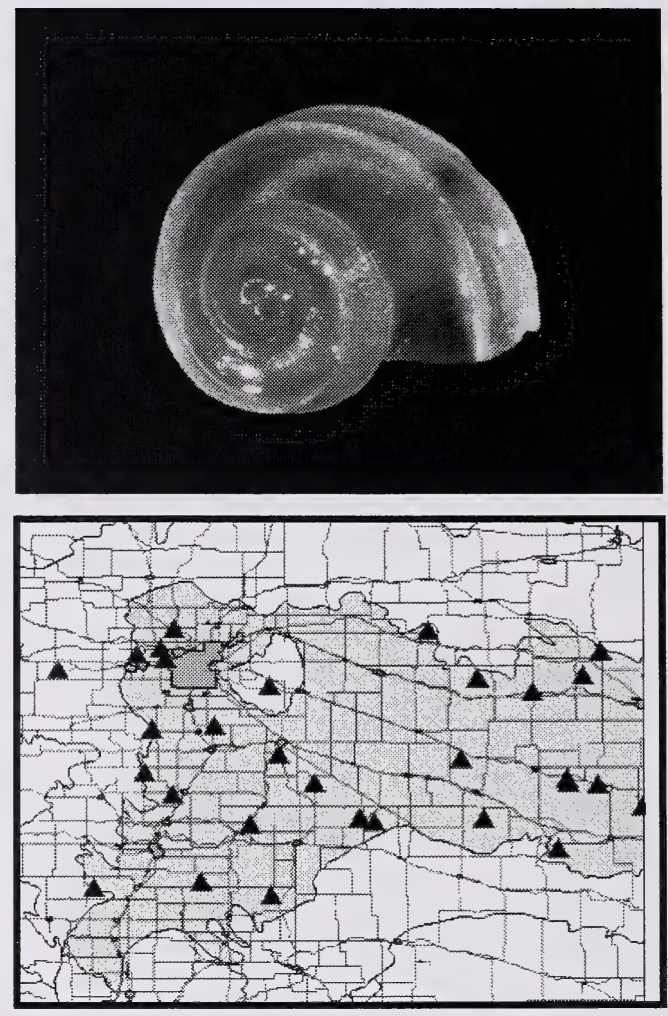

\section{Characteristics}

Present at $31(15.7 \%)$ of 197 sites Alive at $17(8.6 \%)$ of 197 sites

\begin{tabular}{ccc}
\multicolumn{3}{c}{ Wetland Use: } \\
\hline Type & $\begin{array}{c}\% \text { of occupied } \\
\text { sites }\end{array}$ & $\begin{array}{c}\text { Relative to } \\
\text { availability }\end{array}$ \\
\hline River & $35.5 \%$ & $+117.8 \%$ \\
Lake & $51.6 \%$ & $+51.8 \%$ \\
Creek & $3.2 \%$ & $-85.3 \%$ \\
Pond & $9.7 \%$ & $-65.2 \%$ \\
\hline
\end{tabular}

\section{Abundance:}

Mean \#/sample: 304.8 (range: 1-5856)

Rare: $9.7 \%$

Common: $32.3 \%$

Uncommon: $19.4 \%$ Abundant: $38.7 \%$

\section{Water Chemistry:}

\section{All Sites}

Mean pH: 9.0 (range: $7.8-10.0$ )

Mean conductivity: $2.20 \mathrm{mS}$ (range: $0.29-42.65$ )

\section{Sites With Live Specimens}

Mean pH: 9.1 (range: 8.1-10.0)

Mean conductivity: $3.15 \mathrm{mS}$ (range: $0.29-42.65$ ) 


\section{Fossaria dalli}

Dusky fossaria

\section{Current Status: Sensitive}

Fossaria dalli is the smallest species of lymnaeid snail in Alberta. The unique characteristic of this species is the large number of whorls in relation to its small size ( $<6 \mathrm{~mm}$ long) (Clarke 1981; referred to as Bakerilymnaea dalli). The species can also be identified by its round aperture, continuous lip, strongly shouldered whorls, deep sutures, and thread-like collabral lines on the shell surface.

F. dalli has a limited distribution in Canada. Clarke (1981) reported that the species has been found in southern Ontario, and from southern Manitoba to eastern British Columbia. Lee (2000), however, reports that the species has not been found in British Columbia. In the United States, $F$. dalli ranges from Ohio to Arizona (Clarke 1981). The species lives among vegetation in a variety of aquatic habitats (Clarke 1981). Studies done in southern Manitoba in the 1970 s reported $F$. dalli as being rare, but further research conducted in 1998 failed to find this species in the same areas (Pip 2000). In Alberta, F. dalli has been reported from several sites in the Rocky Mountains, Foothills, Parkland and Grasslands Natural Regions, and is likely more common than current records indicate (Lepitzki 2001).

F. dalli has a wide distribution in the Central Parkland Subregion. The species was collected from $19(9.6 \%)$ sites sampled, with the majority of these sites being found in the central and western parts of the region. The species was found in all habitat types, but was most common in rivers and creeks. At the locations where it was found, the species was usually observed to be "rare" or "uncommon" (1-10 individuals). Living specimens were found over a $\mathrm{pH}$ range of 7.8 to 9.5 , and conductivities of 0.50 to 0.82 $\mathrm{mS}$.

Fossaria dalli is widely distributed in the Central Parkland Subregion, which is likely near the northern edge of the species' range. The species occurs over a moderate range of water conditions, but is not very common at sites where it is found.
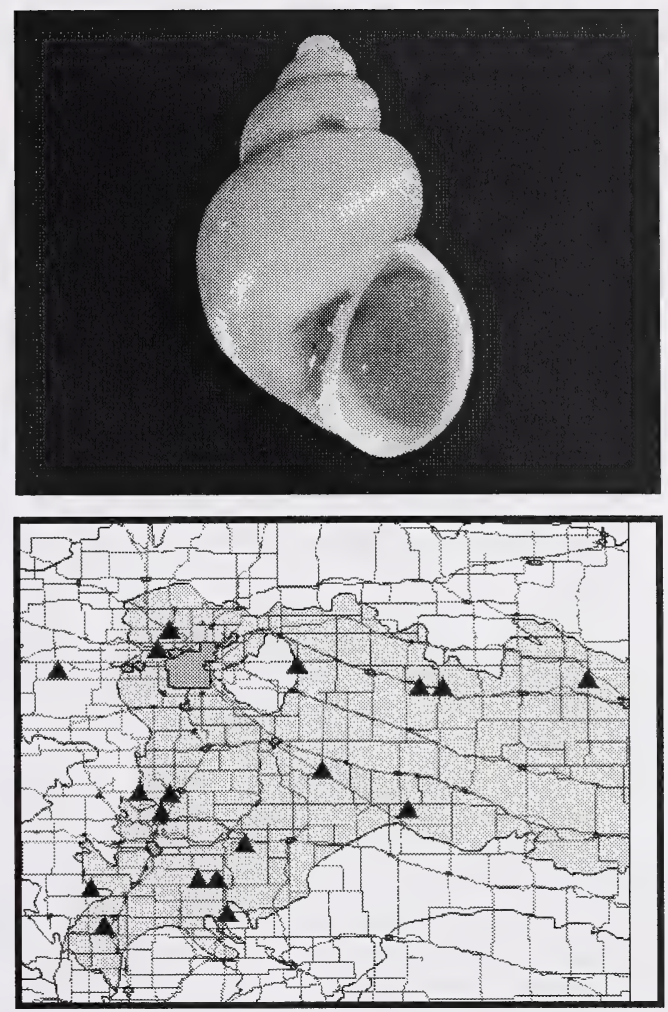

\section{Characteristics}

Present at $19(9.6 \%)$ of 197 sites Alive at $3(1.5 \%)$ of 197 sites

Wetland Use:

\begin{tabular}{lcc}
\hline Type & $\begin{array}{c}\% \text { of occupied } \\
\text { sites }\end{array}$ & $\begin{array}{c}\text { Relative to } \\
\text { availability }\end{array}$ \\
\hline River & $21.1 \%$ & $+29.4 \%$ \\
Lake & $26.3 \%$ & $-22.6 \%$ \\
Creek & $31.6 \%$ & $+45.0 \%$ \\
Pond & $21.1 \%$ & $-24.4 \%$ \\
\hline
\end{tabular}

\section{Abundance:}

Mean \#/sample: 3.8 (range: 1-23)

Rare: $47.4 \%$

Uncommon: $47.4 \%$

\section{Common: $5.3 \%$}

Abundant: $0.0 \%$

\section{Water Chemistry:}

\section{All Sites}

Mean pH: 8.4 (range: 6.0-9.5)

Mean conductivity: $1.19 \mathrm{mS}$ (range: $0.24-6.53$ )

\section{Sites With Live Specimens}

Mean $\mathrm{pH}: 8.8$ (range: 7.8-9.5)

Mean conductivity: $0.64 \mathrm{mS}$ (range: $0.50-0.82$ ) 


\section{Fossaria galbana}

Boreal fossaria

\section{Current Status: Sensitive}

Fossaria galbana is recognized by its small shell size (height $<11 \mathrm{~mm}$ ), dextral coiling and smooth columella. Adults of this species can be distinguished from the other fossarid species by the strongly shouldered whorls, laterally flattened body whorl, reflected inner lip, and distinct aperture shape (narrowly arched above and broadly rounded below) (Clarke 1981; referred to as Fossaria decampi). The shell is commonly thickened and whitish. Burch (1989) recommends that further biological, morphological and conchological research is required for accurate identification of Fossaria species.

F. galbana has a broad distribution across North America, ranging from southern Ontario to eastern British Columbia, and northwest into the subarctic boreal forest region; the distribution in more southern areas needs to be determined (Clarke 1981). F. galbana is characterized as a "cold-water" species, occurring in large northern lakes and rivers among submerged vegetation (Clarke 1981, Burch 1989). In British Columbia, it has been found at several locations in the northern region of the province and is listed as being "apparently secure" (Lee 2000). In Alberta, the species has been recorded from a small number of locations, generally from the Rocky Mountains, Foothills and Boreal Forest Natural Regions (Lepitzki 2001).

Surveys in the Central Parkland Subregion found $F$. galbana to be relatively uncommon and widely scattered across the southern half of the subregion (with one site in the northwestern part of the region at Edmonton). F. galbana was collected from 7 $(3.6 \%)$ sites sampled, and was found exclusively in river and lake habitats. At the locations where it was found, the species was most frequently described as being "uncommon" or "common" (2-100 individuals). Living specimens were found over a $\mathrm{pH}$ range of 6.0 to 9.3 , and conductivities of 0.30 to $3.65 \mathrm{mS}$.

Fossaria galbana is a relatively uncommon and sparsely distributed species in central Alberta. Its preference for larger waterbodies, which are relatively rare in this region, suggests that the current designation of "Sensitive" is likely appropriate.
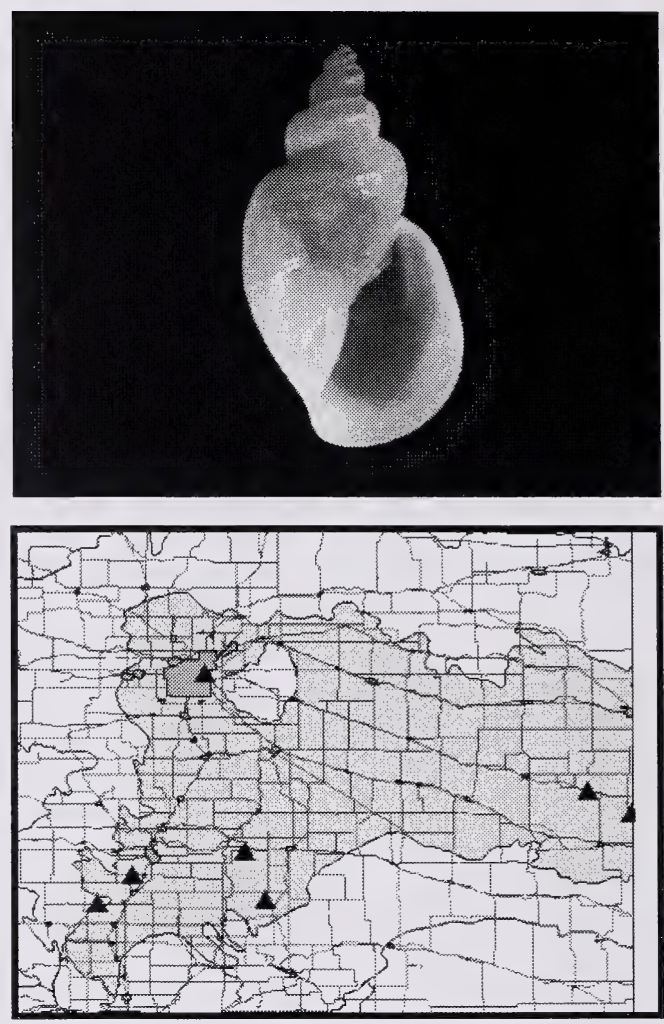

\section{Characteristics}

Present at $7(3.6 \%)$ of 197 sites

Alive at $5(2.5 \%)$ of 197 sites

Wetland Use:

\begin{tabular}{lcc}
\hline Type & $\begin{array}{c}\% \text { of occupied } \\
\text { sites }\end{array}$ & $\begin{array}{c}\text { Relative to } \\
\text { availability }\end{array}$ \\
\hline River & $71.4 \%$ & $+338.0 \%$ \\
Lake & $28.6 \%$ & $-15.9 \%$ \\
Creek & $0.0 \%$ & $-100.0 \%$ \\
Pond & $0.0 \%$ & $-100.0 \%$ \\
\hline
\end{tabular}

\section{Abundance:}

Mean \#/sample: 28.4 (range: 1-152)

Rare: $14.3 \%$

Common: $28.6 \%$

Uncommon: $42.9 \%$

Abundant: $14.3 \%$

\section{Water Chemistry:}

\section{All Sites:}

Mean $\mathrm{pH}: 8.2$ (range: 6.0-9.3)

Mean conductivity: $0.82 \mathrm{mS}$ (range: $0.30-3.65$ )

\section{Sites With Live Specimens:}

Mean pH: 8.1 (range: 6.0-9.3)

Mean conductivity: $1.01 \mathrm{mS}$ (range: $0.30-3.65$ ) 


\section{Fossaria modicella}

Rock fossaria

Current Status: Secure

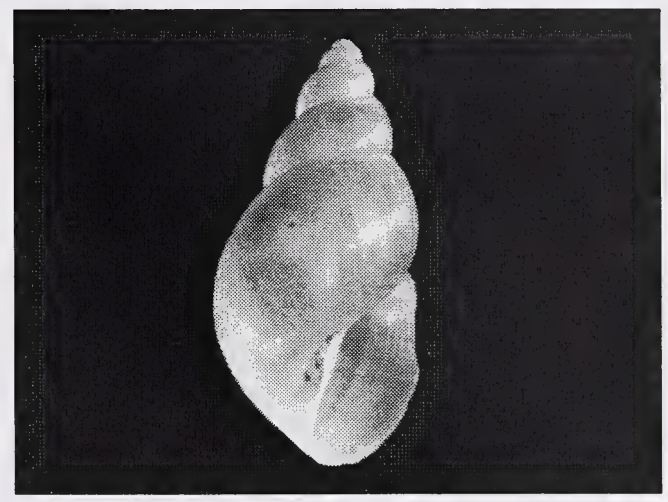

Fossaria modicella is a small lymnaeid with typical dextral coiling, elongated spire and shell length less than $11 \mathrm{~mm}$. This species can be differentiated from the other fossarids by its moderately thin shell and flatly rounded, not shouldered, whorls that increase gradually (Clarke 1981). In addition, adult shells commonly reach a height greater than $7 \mathrm{~mm}$.

The taxonomy of the Fossaria genus is particularly problematic. Burch (1989) lists this species, along with several others, as a member of the Fossaria obrussa group. He recommends that further research is required for accurate identification of Fossaria species. We therefore recognize that $F$. modicella may not be distinct from some other fossarid species in Alberta.

F. modicella has a broad distribution across North America, ranging across Canada from south of the tree line to the southern United States (Clarke 1981). The species occurs in a variety of vernal and perennial waterbodies where vegetation is present (Clarke 1981). F. modicella was observed to be drastically declining in southern Manitoba (Pip 2000). In British Columbia, the species occurs throughout the mainland and is listed as being "secure" (Lee 2000). In Alberta, F. modicella has been collected from at least 17 sites throughout the province, encompassing all natural regions (Lepitzki 2001).

In the Central Parkland Subregion, F. modicella has a very limited distribution. The species was collected from only $2(1.0 \%)$ sites sampled. No living animals were found in either the creek or the pond where shells were found. A maximum of 8 specimens were found, so the species must be considered, at best, to be "uncommon". F. modicella was found over a pH range of 8.5 to 9.4 , and conductivities of 1.64 to 8.65 $\mathrm{mS}$.

Although the status of Fossaria modicella is rated as "Secure" in Alberta, it must be considered to be a rare species in the Central Parkland Subregion. However, the status of this, and other Fossaria species may remain uncertain until taxonomic issues are resolved.

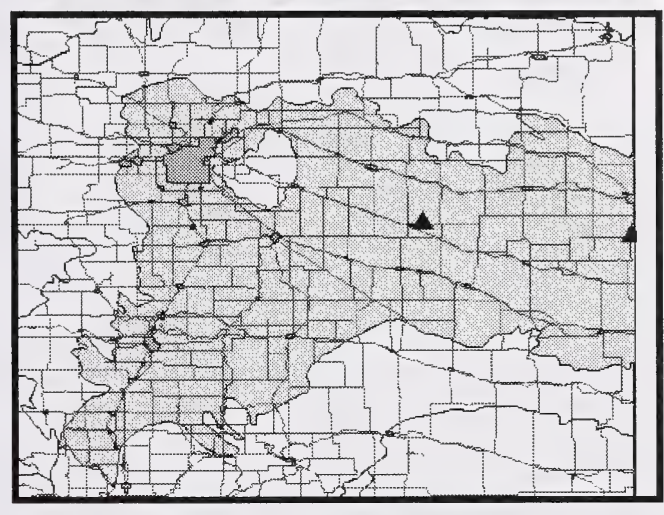

\section{Characteristics}

Present at $2(1.0 \%)$ of 197 sites Alive at $0(0.0 \%)$ of 197 sites

\begin{tabular}{ccc}
\multicolumn{3}{c}{ Wetland Use: } \\
\hline Type & $\begin{array}{c}\% \text { of occupied } \\
\text { sites }\end{array}$ & $\begin{array}{c}\text { Relative to } \\
\text { availability }\end{array}$ \\
\hline River & $0.0 \%$ & $-100.0 \%$ \\
Lake & $0.0 \%$ & $-100.0 \%$ \\
Creek & $50.0 \%$ & $+129.4 \%$ \\
Pond & $50.0 \%$ & $+79.2 \%$ \\
\hline
\end{tabular}

\section{Abundance:}

Mean \#/sample: 4.5 (range: $1-8$ )
Rare: $50.0 \%$

Uncommon: $50.0 \%$

\section{Water Chemistry:}

\section{All Sites}

Mean pH: 9.0 (range: 8.5-9.4)

Mean conductivity: $5.15 \mathrm{mS}$ (range: $1.64-8.65$ )

\section{Sites With Live Specimens}

Mean $\mathrm{pH}$ : N/A

Mean conductivity: N/A 


\section{Lymnaea stagnalis appressa}

Swamp lymnaea

\section{Current Status: Secure}

Lymnaea stagnalis appressa is Alberta's largest aquatic gastropod, with adults reaching a maximum shell height of $56 \mathrm{~mm}$. In addition to the large and thin shell, this species is easily identified by its dextral coiling, large capacious body whorl and long, narrow spire (Clarke 1981; referred to as Lymnaea stagnalis jugularis). Living individuals do not possess an operculum.

L. s. appressa has a broad distribution across North America and is common in most areas of its range. In Canada, the species is found from southern Quebec to British Columbia and north to the tree line (Clarke 1981). It generally lives in all types of perennial waterbodies that are vegetated (Clarke 1981). Pip (2000) describes L. S. appressa as being tolerant of a wide range of water conditions and as a species little affected by human disturbances. It is one of the most frequently encountered species in southern Manitoba (Pip 2000). It is common throughout British Columbia and is listed as "secure" (Lee 2000). In Alberta, the species has previously been found at numerous locations and in all natural regions of the province (Lepitzki 2001).

Surveys in the Central Parkland Subregion confirm this species' broad and common distribution. L. S. appressa was found at $70(35.5 \%)$ sites sampled. It was well represented in all wetland types, but was most frequently found in creeks. In the locations where it was found, the species was most often observed to be "uncommon" (2-10 individuals), but populations were sometimes "abundant" at a site (maximum of 579 individuals). Living specimens were found over a $\mathrm{pH}$ range of 7.0 to 10.7 , which was amongst the widest ranges of all species encountered in the study (Table 3 ). Live animals occurred at conductivities of 0.29 to $3.65 \mathrm{mS}$.

Lymnaea stagnalis appressa has a broad distribution, is relatively common, and has a wide tolerance to water conditions. These factors suggest that the species is "Secure" in Alberta's Central Parkland Subregion.
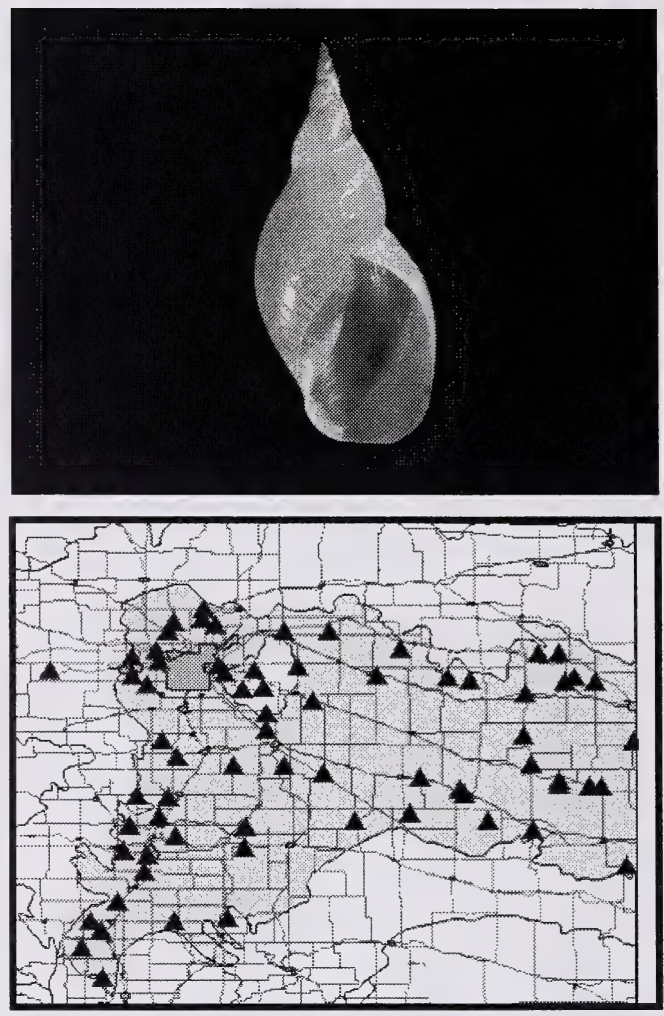

\section{Characteristics}

Present at $70(35.5 \%)$ of 197 sites Alive at $44(22.3 \%)$ of 197 sites

\begin{tabular}{ccc}
\multicolumn{3}{c}{ Wetland Use: } \\
\hline Type & $\begin{array}{c}\% \text { of occupied } \\
\text { sites }\end{array}$ & $\begin{array}{c}\text { Relative to } \\
\text { availability }\end{array}$ \\
\hline River & $12.9 \%$ & $-20.9 \%$ \\
Lake & $35.7 \%$ & $+5.0 \%$ \\
Creek & $27.1 \%$ & $+24.3 \%$ \\
Pond & $24.3 \%$ & $-12.9 \%$ \\
\hline
\end{tabular}

\section{Abundance:}

Mean \#/sample: 15.8 (range: 1-579)

Rare: $22.9 \%$

Uncommon: $55.7 \%$

\section{Water Chemistry:}

\section{All Sites}

Mean pH: 8.8 (range: $7.0-10.7$ )

Mean conductivity: $0.99 \mathrm{mS}$ (range: $0.27-3.65$ )

\section{Sites With Live Specimens}

Mean pH: 8.8 (range: 7.0-10.7)

Mean conductivity: $1.04 \mathrm{mS}$ (range: $0.29-3.65$ ) 


\section{Stagnicola caperata}

Wrinkled marshsnail

\section{Current Status: Secure}

Stagnicola caperata can be easily mistaken for a small $S$. elodes, but closer examination of the shell's surface will differentiate the two species. The shells of adult S. caperata, which do not exceed a height of $16 \mathrm{~mm}$, have unique microscopic, spiral blade-like surface ridges that are best viewed under a microscope (Clarke 1981). In addition, the aperture of $S$. caperata is smaller and ovate and the body whorl is more inflated.

S. caperata is described as a "prairie species". It occurs from southern Manitoba to central Alberta, and extends south into the United States to Nevada and Utah (Clarke 1981). It is found in a wide range of habitats, but most frequently in temporary waterbodies such as ditches, shallow pools, vernal ponds or flooded areas (Clarke 1981). In British Columbia, the species was found to occur mostly in the northern region of the province and is listed as being "apparently secure" (Lee 2000). In Alberta, S. caperata is known to occur at numerous locations in the southern two-thirds of the province, and has been reported from all natural regions except the Canadian Shield (Lepitzki 2001).

Surveys in the Central Parkland Subregion suggest a broad, although relatively sparse, distribution in central Alberta. The species was collected from 14 $(7.1 \%)$ sites sampled, most frequently from creek habitats. The species was, however, found in all wetland types sampled. At the locations where it was found, the species was observed to be "rare" or "uncommon" (1-10 individuals). Living specimens were found over a $\mathrm{pH}$ range of 8.0 to 9.5 , and conductivities of 0.59 to $1.68 \mathrm{mS}$. These values fall in the intermediate range, relative to other species found in this study (Table 3 ).

Stagnicola caperata is a relatively uncommon species in the Central Parkland Subregion of Alberta, but the species has a fairly broad distribution in the area, and occurs over a range of water conditions. Given this, the current status of "Secure" is likely appropriate.
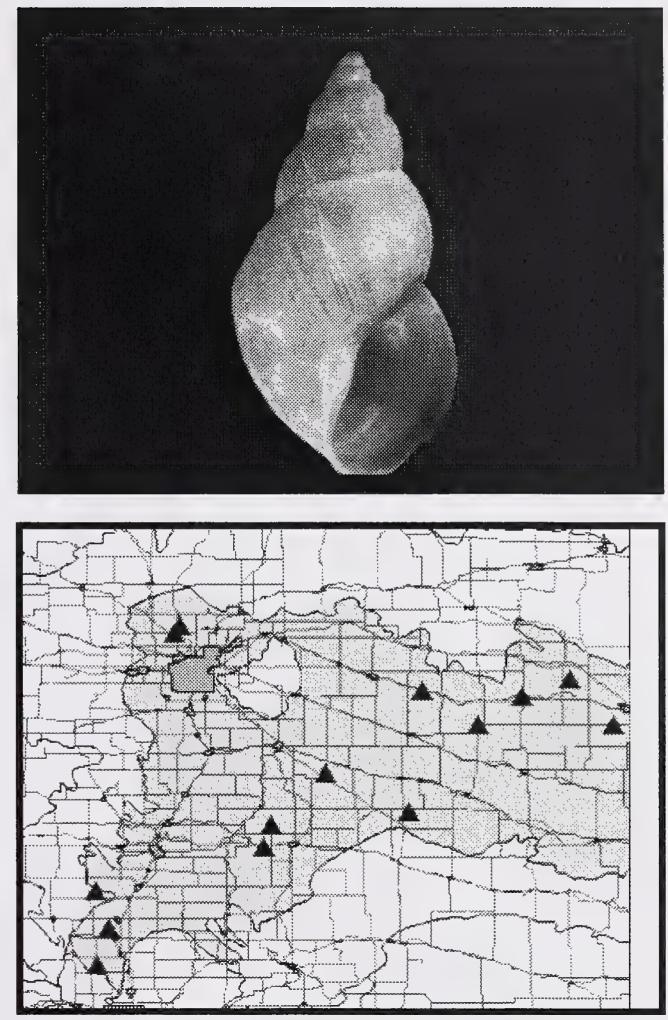

\section{Characteristics}

Present at $14(7.1 \%)$ of 197 sites Alive at $3(1.5 \%)$ of 197 sites

Wetland Use:

\begin{tabular}{ccc}
\hline Type & $\begin{array}{c}\% \text { of occupied } \\
\text { sites }\end{array}$ & $\begin{array}{c}\text { Relative to } \\
\text { availability }\end{array}$ \\
\hline River & $14.3 \%$ & $-12.3 \%$ \\
Lake & $28.6 \%$ & $-15.9 \%$ \\
Creek & $35.7 \%$ & $+63.8 \%$ \\
Pond & $21.4 \%$ & $-23.3 \%$ \\
\hline
\end{tabular}

Abundance:

Mean \#/sample: 9.1 (range: 1-62)

Rare: $50.0 \%$

Common: $14.3 \%$

Uncommon: $35.7 \%$ Abundant: $0.0 \%$

\section{Water Chemistry:}

\section{All Sites}

Mean pH: 8.7 (range: 7.8-9.5)

Mean conductivity: $1.71 \mathrm{mS}$ (range: $0.24-6.53$ )

\section{Sites With Live Specimens}

Mean pH: 8.9 (range: 8.0-9.5)

Mean conductivity: $1.18 \mathrm{mS}$ (range: $0.59-1.68$ ) 


\section{Stagnicola catascopium \\ catascopium}

Woodland pondsnail

\section{Current Status: Undetermined}

Stagnicola catascopium catascopium resembles the widespread S. elodes, although there is substantial intrapopulation variation (Clarke 1981). Typically, S. c. catascopium is distinguished by the large and heavy shell, particularly low spire, rapidly increasing whorls, and heavily sculptured surface (Clarke 1981). In addition, the body whorl is large and dominant, whorls are globose or shouldered, and the aperture is large and flared (Clarke 1973). Identification of Stagnicola species is mostly based on shell morphology, and there is some uncertainty regarding the taxonomy and nomenclature of $S$. catascopium complex (Burch 1989, Lepitzki 2001). The current status of "Undetermined" in Alberta results from this uncertainty (Lepitzki 2001).

S. c. catascopium has a broad distribution across North America, extending from Nova Scotia and Quebec to central British Columbia. The species' range extends south in the United States to approximately $40^{\circ} \mathrm{N}$ (Clarke 1981). S. c. catascopium is associated with large lakes and rivers, but is occasionally found in smaller waterbodies (Clarke 1981). In British Columbia, the species is limited to central and southern interior regions of the province and is listed as being "apparently secure" (Lee 2000). In Alberta, S. c. catascopium has been found at a variety of locations in all natural regions of the province (Lepitzki 2001).

In this survey, S. c. catascopium was found at a single site, south of Elk Point on the North Saskatchewan River. Sixteen living specimens were retrieved, and a pH of 9.0 , and conductivity of 0.34 $\mathrm{mS}$ were measured.

Stagnicola catascopium catascopium evidently has a very restricted range in the Central Parkland Subregion of Alberta. However, proper assessment of the species' status will require additional surveys in the province, as well as clarification of the taxonomy and nomenclature of this, and related, species 


\section{Stagnicola elodes}

Marsh pondsnail

\section{Current Status: Secure}

Stagnicola elodes is Alberta's most common Stagnicola species. This medium to large species can be identified by its dextral coiling, solid shell, conically elongated spire, and red lip band and apex (Clarke 1981). Individual adults exhibit heavily malleated or "hammered-like" shells, a heavy and twisted columella, and gradually increasing whorls.

S. elodes has a broad distribution across North America, occurring throughout Canada below the tree line and extending into the northern United States to approximately $38^{\circ} \mathrm{N}$ (Clarke 1981). The species is found in a variety of aquatic habitats, especially heavily vegetated types, and is abundant in all areas of its range (Clarke 1981). According to Pip (2000), S. elodes is tolerant of wide range of water conditions and is one of the species least affected by human disturbances. It is one of the most frequently encountered species in southern Manitoba (Pip 2000). In British Columbia, it occurs throughout the province and is listed as "secure" (Lee 2000). In Alberta, the species has been found in all natural regions (Lepitzki 2001).

Surveys in the Central Parkland Subregion confirm this species' broad and common distribution. $S$. elodes was one of the most frequently encountered species (Table 2). The species was collected from $89(45.2 \%)$ of all sites sampled, and was most frequently found in smaller waterbodies (creeks and ponds). Where it was found, $S$. elodes was most often observed to be "uncommon" or "common" (2100 individuals), with a maximum of 308 individuals being collected at a site. Living specimens were found over a pH range of 6.0 to 9.8 , and conductivities of 0.30 to $16.11 \mathrm{mS}$. These ranges are among the widest of all species observed in the study (Table 3).

Stagnicola elodes has a broad distribution, common occurrence, high abundance and a wide tolerance to water conditions. These factors confirm that the status of this species is "Secure" in the Central Parkland Subregion of Alberta.
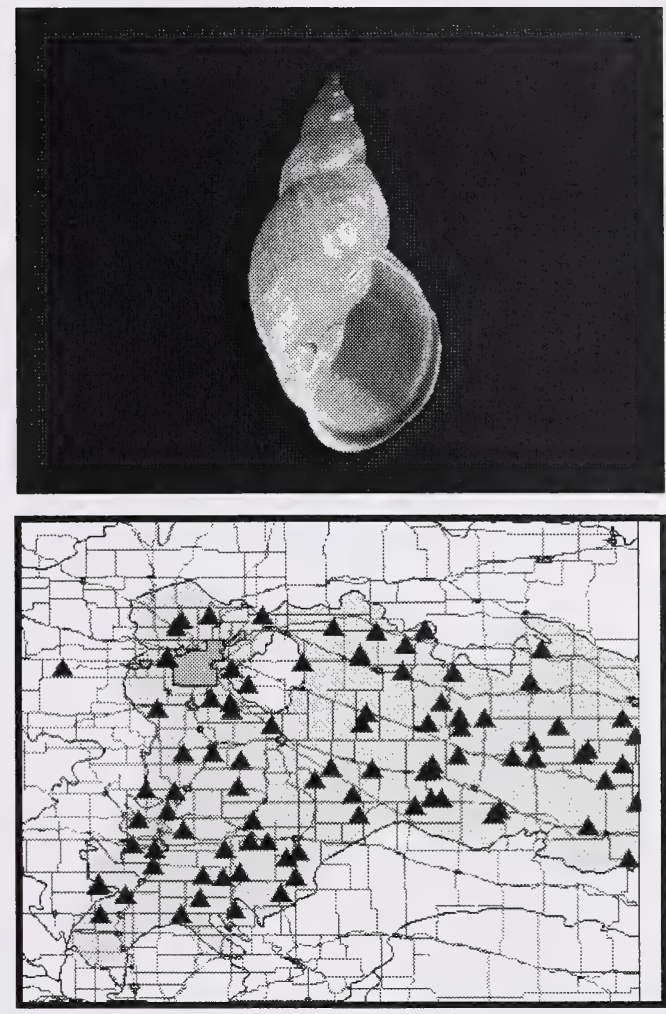

\section{Characteristics}

Present at $89(45.2 \%)$ of 197 sites Alive at $41(20.8 \%)$ of 197 sites

Wetland Use:

\begin{tabular}{ccc}
\hline Type & $\begin{array}{c}\text { \% of occupied } \\
\text { sites }\end{array}$ & $\begin{array}{c}\text { Relative to } \\
\text { availability }\end{array}$ \\
\hline River & $11.2 \%$ & $-31.3 \%$ \\
Lake & $22.5 \%$ & $-33.8 \%$ \\
Creek & $28.1 \%$ & $+28.9 \%$ \\
Pond & $38.2 \%$ & $+36.9 \%$ \\
\hline
\end{tabular}

Abundance:

Mean \#/sample: 21.5 (range: 1-308)

Rare: $13.5 \%$

Common: $34.5 \%$

Uncommon: $48.3 \%$ Abundant: $3.4 \%$

\section{Water Chemistry:}

\section{All Sites}

Mean pH: 8.6 (range: 6.0-10.7)

Mean conductivity: $2.12 \mathrm{mS}$ (range: $0.24-16.28$ )

\section{Sites With Live Specimens}

Mean pH: 8.5 (range: 6.0-9.8)

Mean conductivity: $1.93 \mathrm{mS}$ (range: $0.30-16.11$ ) 


\section{Stagnicola exilis}

Flat-whorled pondsnail

\section{Current Status: Undetermined}

Stagnicola exilis is comparable to S. elodes and can be identified by similar shell features: medium height, dextral coiling and a long spire with gradually increasing whorls. However, S. exilis can be differentiated by its narrower pyramid-like form, flatsided whorls, and zebra-like colored bands (Clarke 1981). There is some speculation that $S$. exilis might actually be a variant of $S$. elodes (Clarke 1973, 1981). This lack of taxonomic clarity led Lepitzki (2001) to assign an "Undetermined" status to S. exilis in Alberta. In the present study, we treated $S$. exilis as a distinct species, while recognizing the taxonomic uncertainty.

S. exilis has a scattered distribution, occurring across southern Canada from Quebec to Alberta, and south into the upper Ohio-Mississippi drainage to approximately $37^{\circ} \mathrm{N}$ (Clarke 1981). The species occurs in a variety of perennial and vernal habitats such as lakes, ponds, swamps, ditches and some streams among vegetation where the substrate is mud (Clarke 1981). S. exilis is not listed as a species that occurs in British Columbia (Lee 2000). In Alberta, it has been previously found at a small number of sites, primarily in the Rocky Mountains, Foothills, Parkland and Grassland Natural Regions of the province (Lepitzki 2001).

The present study shows the species to have a sparse distribution across the northern and eastern parts of the Central Parkland Subregion. S. exilis was collected from $5(2.5 \%)$ sites sampled, and occurred most frequently in creek and pond habitats. At the locations where it was found, the species was observed to be "rare" or "uncommon" (1-10 individuals). Living specimens were found at only one site where a pH of 9.2 , and a conductivity of $0.46 \mathrm{mS}$ were measured.

If our criteria for identifying $S$. exilis are correct, then the species should be considered to be uncommon in the Central Parkland Subregion. However, we concur with Lepitzki (2001) that the taxonomy of this, and similar species, must be clarified before a proper status assessment can be attempted.
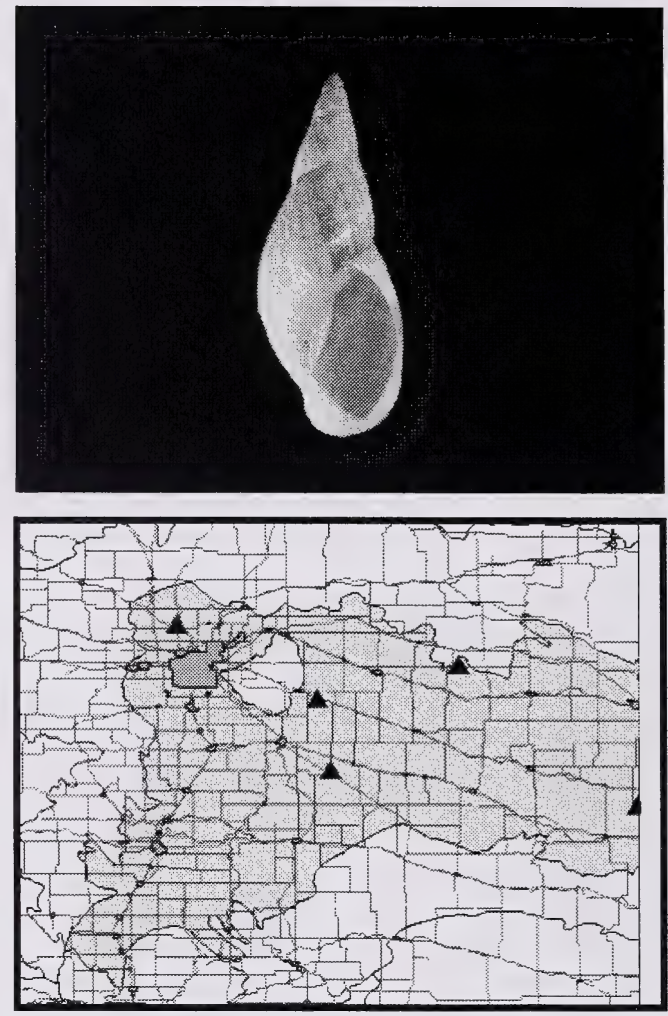

\section{Characteristics}

Present at $5(2.5 \%)$ of 197 sites

Alive at $1(0.5 \%)$ of 197 sites

Wetland Use:

\begin{tabular}{ccc}
\hline Type & $\begin{array}{c}\% \text { of occupied } \\
\text { sites }\end{array}$ & $\begin{array}{c}\text { Relative to } \\
\text { availability }\end{array}$ \\
\hline River & $0.0 \%$ & $-100.0 \%$ \\
Lake & $20.0 \%$ & $-41.2 \%$ \\
Creek & $40.0 \%$ & $+83.5 \%$ \\
Pond & $40.0 \%$ & $+43.4 \%$ \\
\hline
\end{tabular}

\section{Abundance:}

Mean \#/sample: 4.6 (range: 1-16)

Rare: $40.0 \%$

Uncommon: $40.0 \%$

\section{Common: $20.0 \%$} Abundant: $0.0 \%$

\section{Water Chemistry:}

\section{All Sites}

Mean pH: 8.7 (range: 7.8-9.6)

Mean conductivity: $1.0 \mathrm{mS}$ (range: $0.46-1.41$ )

\section{Sites With Live Specimens}

Mean pH: 9.2 (range: N/A)

Mean conductivity: $0.46 \mathrm{mS}$ (range: N/A) 


\section{Aplexa elongata}

Lance aplexa

\section{Current Status: Secure}

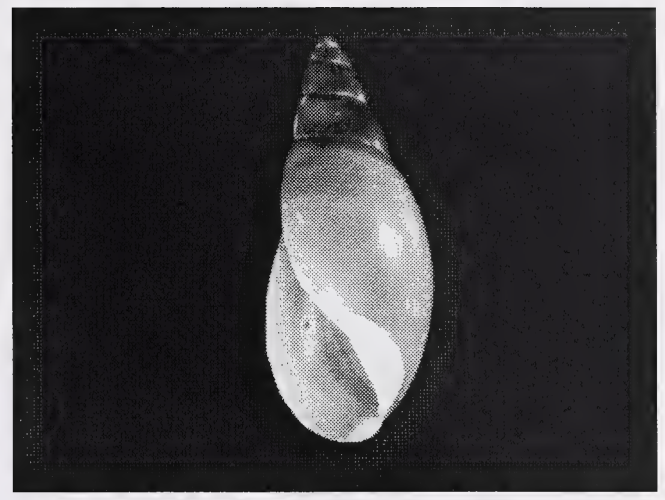

Aplexa elongata can be identified without difficulty by its medium-sized spindle-shaped shell, sinistral coiling, and long narrow spire (Clarke 1981; referred to as Aplexa hypnorum). The mantle edge of live individuals is smooth, without digitations (finger-like projections), and does not extend beyond the aperture (Burch 1989). As well, the shell surface appears to be glossy and blackish.

A. elongata is widely distributed across North America, ranging from Nova Scotia to James Bay, across to the west coast of British Columbia, and north to arctic Alaska (Clarke 1981). Most frequently, the species lives in vernal habitats but it can occasionally be found in large permanent rivers and lakes (Clarke 1981). In southern Manitoba, A. elongata consistently showed a high frequency of occurrence in agricultural areas (Pip 2000). In British Columbia, the species has been collected from several locations in central and eastern areas of the province and is listed as being "apparently secure" (Lee 2000). In Alberta, A. elongata has been recorded from a moderate number of lakes, rivers and sloughs throughout the province (Lepitzki 2001).

In the Central Parkland Subregion, $A$. elongata has a fairly broad, but sparse distribution. The species was collected from $11(5.6 \%)$ sites sampled, representing all four wetland types. The species was, however, most common in creeks and ponds. At the locations where it was found the species was most often observed to be "rare" or "uncommon" (1-10 individuals), and no more than 12 specimens were retrieved from a site. Living specimens were found at only one site where a pH of 7.8 and a conductivity of $0.82 \mathrm{mS}$ were measured.

Aplexa elongata is currently listed as a "Secure" species in Alberta. However, our survey found that the species is sparsely distributed in the Central Parkland Subregion, and populations at occupied sites are fairly low. The status of this species may require reconsideration.

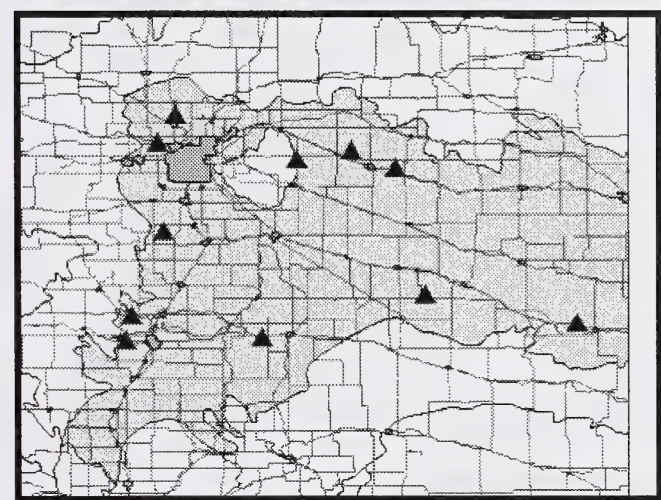

\section{Characteristics}

Present at $11(5.6 \%)$ of 197 sites Alive at $1(0.5 \%)$ of 197 sites

Wetland Use:

\begin{tabular}{lcc}
\hline Type & $\begin{array}{c}\% \text { of occupied } \\
\text { sites }\end{array}$ & $\begin{array}{c}\text { Relative to } \\
\text { availability }\end{array}$ \\
\hline River & $9.1 \%$ & $-44.2 \%$ \\
Lake & $27.3 \%$ & $-19.7 \%$ \\
Creek & $27.3 \%$ & $+25.2 \%$ \\
Pond & $36.4 \%$ & $+30.5 \%$ \\
\hline
\end{tabular}

\section{Abundance:}

Mean \#/sample: 3.0 (range: 1-12)

Rare: $45.5 \%$

Common: $9.1 \%$

Uncommon: $45.5 \%$ Abundant: $0.0 \%$

\section{Water Chemistry:}

\section{All Sites}

Mean $\mathrm{pH}: 8.3$ (range: $7.7-9.6$ )

Mean conductivity: $2.62 \mathrm{mS}$ (range: $0.43-16.11$ )

\section{Sites With Live Specimens}

$$
\text { Mean } \mathrm{pH}: 7.8 \text { (range: N/A) }
$$

Mean conductivity: $0.82 \mathrm{mS}$ (range: N/A) 


\section{Physa skinneri}

Glass physa

Current Status: Undetermined

Physa skinneri can be identified by the thin and fragile shell, sinistral coiling, blunt apex, and laterally flatted body whorl (Clarke 1981; referred to as Physa jennessi skinneri). The mantle edge of live specimens is digitated and reflected over both sides of the shell (Burch 1989). According to Taylor (1988) $P$. skinneri looks similar to $P$. megalochlamys, a recently defined species that occurs in the northwestern U.S. and adjacent areas of Canada. Given this, Lepitzki (2001) suggests that identifications of $P$. skinneri in Alberta be reevaluated, and he assigned a status of "Undetermined" to both species. We did not attempt to distinguish between the two species in this study. Some specimens identified as $P$. skinneri may therefore be $P$. megalochlamys.

P. skinneri has a broad distribution in North America, from eastern Ontario to Great Slave Lake and into British Columbia (Clarke 1981). The species occurs on muddy bottoms among vegetation in all types of slow moving waterbodies (Clarke 1981, Taylor 1988). In British Columbia, the species has been identified from one location, but is suspected to occur throughout the province. It is listed as being "apparently secure" in that province (Lee 2000). P. skinneri has been found in all natural regions of Alberta (Lepitzki 2001).

Surveys in the Central Parkland Subregion confirm this species' broad and common distribution. $P$. skinneri was the second most-encountered species and the sixth highest in terms of abundance (Table 2). The species was collected from $93(47.2 \%)$ sites sampled, and occurred in all wetland types (especially ponds). Where it was found, the species was usually observed to be "uncommon" (2-10 individuals), although a maximum of 228 individuals were found at one site. Living specimens were found over a pH range of 7.4 to 10.7 , and at conductivities of 0.33 to $8.78 \mathrm{mS}$. Few species were found at higher values of $\mathrm{pH}$ and conductivity (Table 3 ).

Physa skinneri is a widespread and common species in the Central Parkland Subregion of Alberta. Populations are likely "Secure" in this area, although taxonomic confusion with $P$. megalochlamys requires resolution. 


\section{Physella gyrina}

Tadpole physa

\section{Current Status: Secure}

Physella gyrina is distinguished from the other physids in Alberta by the large inflated body whorl, pointed spire, and small, acute and reddish apex (Clarke 1981; referred to as Physa gyrina gyrina). In live individuals, the mantle edge is digitated (has finger-like projections) and is reflected over the outer lip of the aperture (Burch 1989). This is the largest physid species in Alberta, with adults attaining a maximum height of $24 \mathrm{~mm}$ (Clarke 1981).

$P$. gyrina is widely distributed across North America, and is described as being abundant in most areas of its range (Clarke 1981). The species has been found in ponds, rocky lakeshore areas and in intermediate habitat types, but always in very shallow water (Clampitt 1970). In southern Manitoba, it is one of the most frequently encountered species (Pip 2000). In British Columbia, it occurs throughout the province and is listed as "secure" (Lee 2000). In Alberta, P. gyrina has been found in perennial and temporary waterbodies, and is often abundant in areas with high organic pollution (Lepitzki 2001). According to Clampitt (1970), the species can withstand high water temperatures $\left(35-40^{\circ} \mathrm{C}\right)$, as well as significant dry periods. Pip (2000) describes $P$. gyrina as being tolerant of human disturbances and a wide range of water conditions.

Surveys in the Central Parkland Subregion confirm this species' broad distribution and common occurrence. Overall, $P$. gyrina was the fifth mostencountered species and the fourth highest in abundance (Table 2). The species was found at 74 $(37.6 \%)$ sites sampled, and in a wide range of habitat types. The species was somewhat more common in rivers, and less common in ponds than in other habitats. $P$. gyrina was observed to be "uncommon" or "common" (2-100 individuals) at most sites where it was found. Living specimens were found at a higher percentage $(25.4 \%)$ of sites (Table 2), and over a wider $\mathrm{pH}$ range $(6.0$ to 10.2$)$, than any other species found in this survey (Table 3 ).

The broad distribution, common occurrence, high abundance and wide $\mathrm{pH}$ tolerance confirm that Physella gyrina is a "Secure" species in Alberta's Central Parkland Subregion.
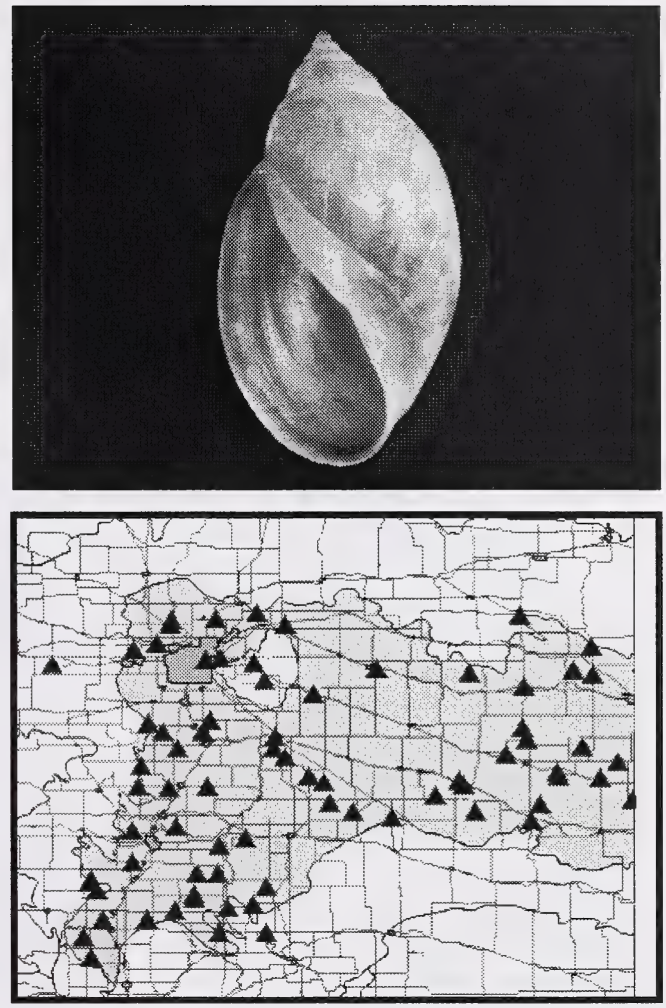

\section{Characteristics}

Present at $74(37.6 \%)$ of 197 sites Alive at $50(25.4 \%)$ of 197 sites

Wetland Use:

\begin{tabular}{lcc}
\hline Type & $\begin{array}{c}\% \text { of occupied } \\
\text { sites }\end{array}$ & $\begin{array}{c}\text { Relative to } \\
\text { availability }\end{array}$ \\
\hline River & $37.8 \%$ & $+131.9 \%$ \\
Lake & $31.1 \%$ & $-8.5 \%$ \\
Creek & $21.6 \%$ & $-0.9 \%$ \\
Pond & $9.5 \%$ & $-65.9 \%$ \\
\hline
\end{tabular}

\section{Abundance:}

Mean \#/sample: 29.1 (range: 1-458)

Rare: $13.5 \%$ Common: $36.5 \%$ Uncommon: $44.6 \%$ Abundant: $5.4 \%$

\section{Water Chemistry:}

\section{All Sites}

Mean pH: 8.8 (range: 6.0-10.2)

Mean conductivity: $0.80 \mathrm{mS}$ (range: $0.24-4.08$ )

\section{Sites With Live Specimens}

Mean pH: 8.7 (range: $6.0-10.2$ )

Mean conductivity: $0.62 \mathrm{mS}$ (range: $0.24-2.50$ ) 


\section{Gyraulus circumstriatus}

Disc gyro

\section{Current Status: Secure}

Gyraulus circumstriatus can be identified by its small size (shell $<5 \mathrm{~mm}$ wide), planorbid form and dextral coiling, all of which are typical features of this genus. However, unlike $G$. parvus and $G$. deflectus, the apical and umbilical views of this species look very similar and the body whorl is evenly rounded (Clarke 1981). As well, the shell is semi-transparent (revealing the soft parts of the living animal) and the whorls increase slowly and symmetrically. However, the species is sometimes difficult to distinguish from other species of Gyraulus (Clarke 1981). Clarke (1973) believed that "revision of the difficult genus Gyraulus is especially desirable".

G. circumstriatus has a broad distribution across North America, from Prince Edward Island to New England, west to northern British Columbia and south in the Rocky Mountains to New Mexico (Clarke 1981). The species is found in vernal habitats such as woodland pools, marshes, roadside ditches, prairie ponds and intermittent streams, and is always associated with thick vegetation and muddy substrates (Clarke 1981). In British Columbia, it occurs throughout the province and is listed as "secure" (Lee 2000). In Alberta, G. circumstriatus has been found in all natural regions, but may be absent from the far northeastern corner of the province (Lepitzki 2001).

Surveys in the Central Parkland Subregion confirm this species' wide distribution. G. circumstriatus was collected from $46(23.4 \%)$ sites sampled, and was almost equally represented in the different wetland types. At the locations where it was found the species was observed to be mostly "uncommon" or "common" (2-100 individuals). Living specimens were found over a $\mathrm{pH}$ range of 7.8 to 10.7 , and conductivities of 0.29 to $4.29 \mathrm{mS}$.

The broad distribution of Gyraulus circumstriatus, along with its relatively high abundance and equal representation in all habitat types confirms that this species is "Secure" in Alberta's Central Parkland Subregion.

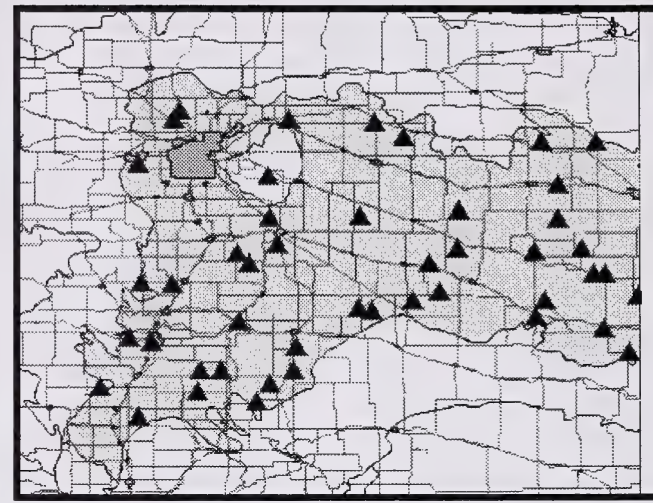

\section{Characteristics}

Present at $46(23.4 \%)$ of 197 sites Alive at $22(11.2 \%)$ of 197 sites

Wetland Use:

\begin{tabular}{ccc}
\hline Type & $\begin{array}{c}\% \text { of occupied } \\
\text { sites }\end{array}$ & $\begin{array}{c}\text { Relative to } \\
\text { availability }\end{array}$ \\
\hline River & $15.2 \%$ & $-6.7 \%$ \\
Lake & $32.6 \%$ & $-4.1 \%$ \\
Creek & $23.9 \%$ & $+9.6 \%$ \\
Pond & $28.3 \%$ & $+1.4 \%$ \\
\hline
\end{tabular}

\section{Abundance:}

Mean \#/sample: 25.2 (range: 1-216)

Rare: $15.2 \%$

Uncommon: $45.7 \%$

Common: $30.4 \%$ Abundant: $8.7 \%$

\section{Water Chemistry:}

\section{All Sites}

Mean pH: 8.9 (range: 7.5-10.7)

Mean conductivity: $2.31 \mathrm{mS}$ (range: $0.29-16.28$ )

\section{Sites With Live Specimens}

Mean pH: 9.1 (range: 7.8-10.7)

Mean conductivity: $1.28 \mathrm{mS}$ (range: $0.29-4.29$ ) 


\section{Gyraulus crista}

Star gyro

Current Status: Sensitive

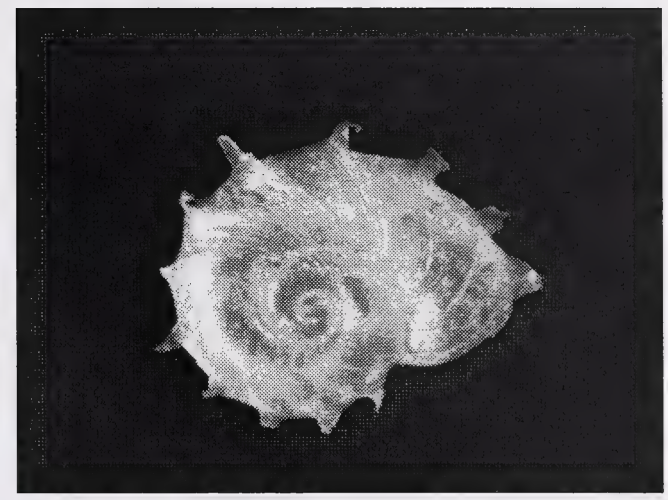

Gyraulus crista is Alberta's smallest aquatic gastropod. At a diameter of less than $3 \mathrm{~mm}$ and a height of $1 \mathrm{~mm}$ it can be easily overlooked. However, this minute species can be quickly identified by its prominent triangular ridges on the body whorl, flat spire, and continuous lip that surrounds the aperture (Clarke 1981; referred to as Armiger crista). Some specimens exhibit loose and partly detached coiling (Clarke 1981).

G. crista has a scattered distribution across North America, occurring in Alaska and the Northwest Territories, and from southern Ontario to western Alberta and south into the United States from Maine to Minnesota (Clarke 1981). It has been described as being "rare or occasional" in most areas of its range, but "common" in the Canadian Interior Basin (Clarke 1973, Lepitzki 2001). G. crista lives among dense vegetation in eutrophic ponds and slow moving streams (Clarke 1981). In southern Manitoba, populations of $G$. crista are thought to be declining (Pip 2000). In British Columbia, the species has been found only in central and eastern regions of the province and is listed as being "apparently secure" in that province (Lee 2000). In Alberta, G. crista has been collected mostly in the southern twothirds of the province. Records are known for all natural regions in the province, with the exception of the Canadian Shield (Lepitzki 2001).

Surveys in the Central Parkland Subregion found G. crista to be relatively common and widespread. The species was collected from 59 (30.0\%) sites sampled. Although it was found in all types of wetlands, the species was particularly associated with ponds. At the locations where it was found the species was most often observed to be "uncommon" (2-10 individuals), but occasionally reached high abundance (maximum of 778 individuals at a site). Living specimens were found over a $\mathrm{pH}$ range of 7.7 to 9.5 , and conductivities of 0.45 to $3.01 \mathrm{mS}$.

Gyraulus crista is a common and widespread species in the Central Parkland Subregion, and should probably be considered to be "Secure" in the area.

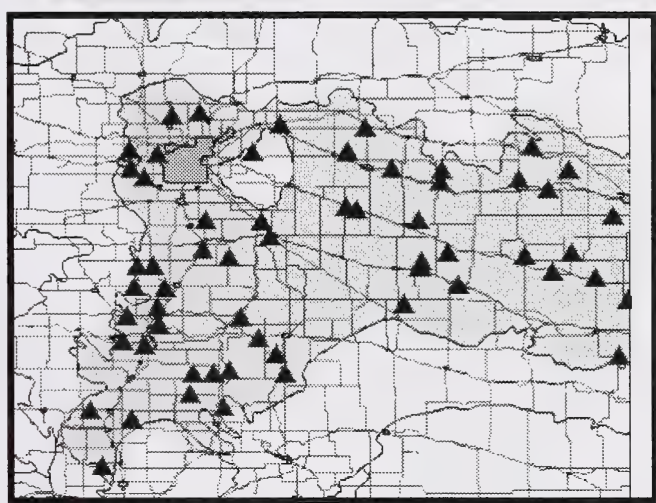

\section{Characteristics}

Present at $59(30.0 \%)$ of 197 sites Alive at $15(7.6 \%)$ of 197 sites

Wetland Use:

\begin{tabular}{ccc}
\hline Type & $\begin{array}{c}\% \text { of occupied } \\
\text { sites }\end{array}$ & $\begin{array}{c}\text { Relative to } \\
\text { availability }\end{array}$ \\
\hline River & $5.1 \%$ & $-68.7 \%$ \\
Lake & $30.5 \%$ & $-10.3 \%$ \\
Creek & $20.3 \%$ & $-6.9 \%$ \\
Pond & $44.1 \%$ & $+58.1 \%$ \\
\hline
\end{tabular}

\section{Abundance:}

Mean \#/sample: 22.1 (range: 1-778)

Rare: $27.1 \%$

Uncommon: $47.5 \%$

Common: $22.0 \%$

Abundant: $3.4 \%$

\section{Water Chemistry:}

\section{All Sites}

Mean pH: 8.6 (range: 7.4-10.7)

Mean conductivity: $2.0 \mathrm{mS}$ (range: $0.29-16.28$ )

\section{Sites With Live Specimens}

Mean pH: 8.7 (range: 7.7-9.5)

Mean conductivity: $1.34 \mathrm{mS}$ (range: $0.45-3.01$ ) 


\section{Gyraulus deflectus}

Flexed gyro

\section{Current Status: Secure}

Gyraulus deflectus is the province's largest Gyraulus species, with adults having $4 \frac{1}{2}$ whorls and attaining a maximum shell diameter of $8 \mathrm{~mm}$ (Clarke 1981). In addition to the large size, the species can be distinguished from other members of its genus by any combination of shell characteristics such as the hairy periostracum, peripheral keel, or surface malleations. Unlike $G$. circumstriatus, the apical and umbilical views look clearly different.

G. deflectus has a broad distribution across North America, ranging throughout all of Canada and Alaska, north to the central arctic, and south in the United States to Virginia and Nebraska (Clarke 1981). The species occurs in all types of permanent, eutrophic waterbodies and is not found in ditches or habitats that dry out (Clarke 1973). G. deflectus is found throughout British Columbia and is listed as "secure" in that province (Lee 200). In Alberta, the species has been previously found in lakes, creeks, rivers and sloughs and in all natural regions of the province (Lepitzki 2001).

Surveys in the Central Parkland Subregion confirm this species' broad and common distribution. G. deflectus was the most frequently encountered species in this inventory, and the third highest in total abundance (3598 individuals; see Table 2). The species was collected from 108 (54.8\%) sites sampled. G. deflectus was found in a wide variety of habitat types, but was over-represented in smaller waterbodies (ponds and creeks). At locations where it was found, the species was most frequently observed to be "uncommon" or "common" (2-100 individuals), with a maximum of 384 individuals being found at a site. Living specimens were found over a $\mathrm{pH}$ range of 6.0 to 9.9 , and conductivities of 0.24 to $6.50 \mathrm{mS}$. These ranges are among the widest of all species recorded in the Central Parkland Subregion (Table 3).

The broad distribution, common occurrence, high abundance and wide tolerance to water conditions confirm that Gyraulus deflectus is a "Secure" species in the Central Parkland Subregion of Alberta.
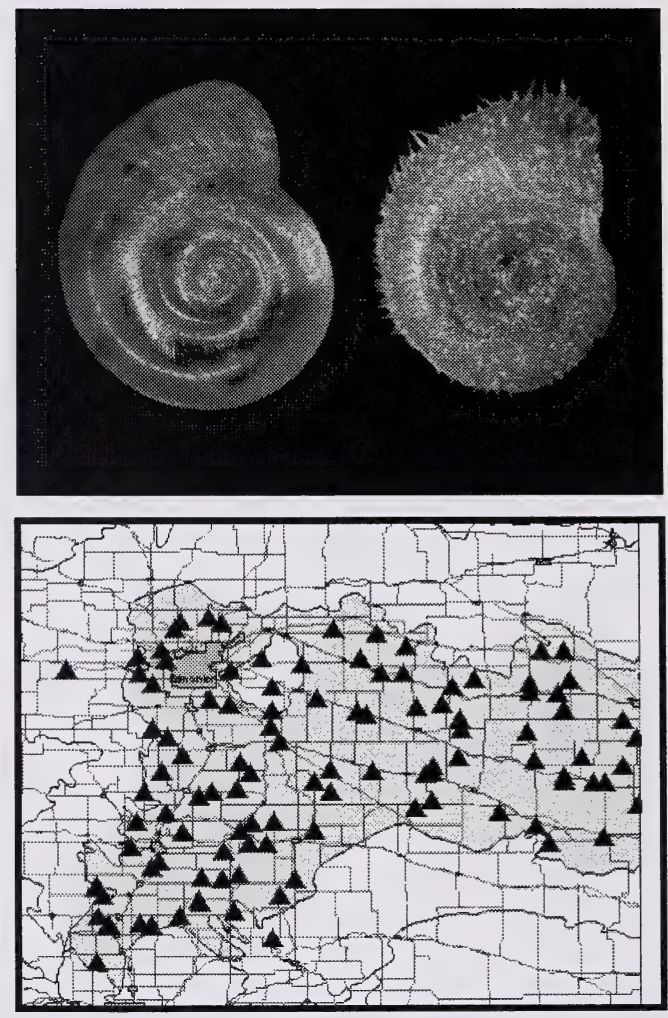

\section{Characteristics}

Present at $108(54.8 \%)$ of 197 sites Alive at $29(14.7 \%)$ of 197 sites

\begin{tabular}{ccc}
\multicolumn{3}{c}{ Wetland Use: } \\
\hline Type & $\begin{array}{c}\% \text { of occupied } \\
\text { sites }\end{array}$ & $\begin{array}{c}\text { Relative to } \\
\text { availability }\end{array}$ \\
\hline River & $11.1 \%$ & $-31.9 \%$ \\
Lake & $30.6 \%$ & $-10.0 \%$ \\
Creek & $24.1 \%$ & $+10.6 \%$ \\
Pond & $34.3 \%$ & $+22.9 \%$ \\
\hline
\end{tabular}

\section{Abundance:}

Mean \#/sample: 33.1 (range: 1-384)

Rare: $12.0 \%$

Uncommon: $38.9 \%$

\section{Water Chemistry:}

\section{All Sites}

Mean pH: 8.7 (range: $6.0-10.7$ )

Mean conductivity: $1.82 \mathrm{mS}$ (range: $0.24-16.28$ )

\section{Sites With Live Specimens}

Mean pH: 8.6 (range: 6.0-9.9)

Mean conductivity: $1.58 \mathrm{mS}$ (range: $0.24-6.50$ ) 


\section{Gyraulus parvus}

Ash gyro

\section{Current Status: Secure}

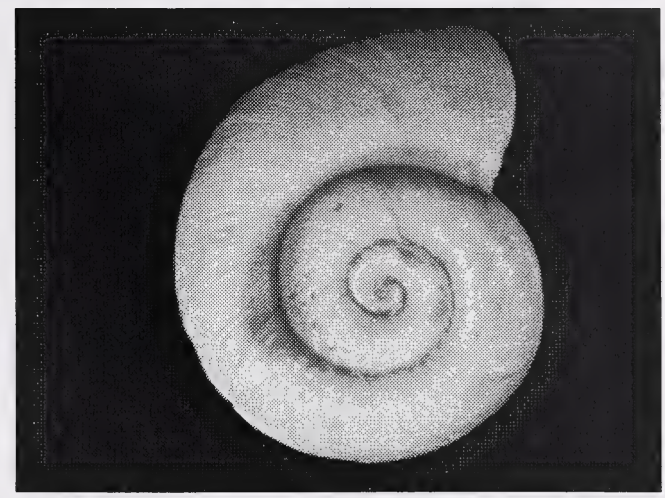

Gyraulus parvus is identified by its small shell size ( $<5 \mathrm{~mm}$ wide), planorbid form and dextral coiling which are typical features of this genus. Unlike $G$. circumstriatus, the apical and umbilical views of this species look very different. In addition, the shell lacks a peripheral keel, malleations, or hirsute periostracum (Clarke 1981). Despite these defining characteristics, there are sometimes problems with identification of this species. According to Clarke (1973), "even positive differentiation of $G$. parvus from some specimens of $G$. circumstriatus and $G$. deflectus is not always easy".

G. parvus has a broad distribution across North America, occurring throughout Canada and the United States south of the tree line. It is described as being abundant throughout its range (Clarke 1981). The species lives on submerged aquatic vegetation in various permanent or temporary waterbodies that support plant growth (Clarke 1981). In southern Manitoba, populations of G. parvus were observed to be drastically declining (Pip 2000). In British Columbia, the species is found throughout the province and the population size is believed to be large. It is listed as "secure" in that province (Lee 2000). In Alberta, G. parvus has been found at approximately 80 locations throughout the province, in all natural regions (Lepitzki 2001).

Surveys in the Central Parkland Subregion confirm this species' wide distribution and high abundance. $G$. parvus was the second most abundant species encountered (Table 2). The species was collected from $67(34.0 \%)$ sites sampled, and was well represented in all wetland types. At the locations where it was found the species was usually observed to be "uncommon" or "common" (2-100 individuals), and occasionally was very abundant (maximum of 1944 individuals). Living specimens were found over a pH range of 7.7 to 9.5 , and conductivities of 0.24 to $0.77 \mathrm{mS}$.

The broad distribution, common occurrence, and high abundance of $G$. parvus suggest that this species is "Secure" in Alberta's Central Parkland Subregion.

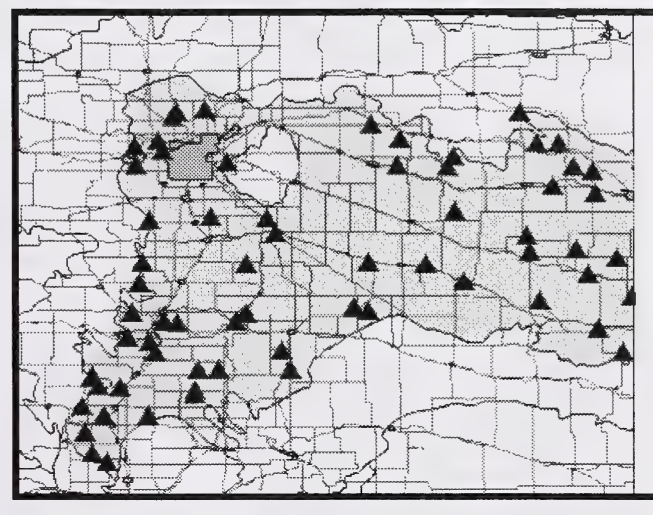

\section{Characteristics}

Present at $67(34.0 \%)$ of 197 sites Alive at $4(2.0 \%)$ of 197 sites

Wetland Use:

\section{Abundance:}

Mean \#/sample: 85.0 (range: 1-1944)

Rare: $7.5 \%$

Common: $34.3 \%$

Uncommon: $44.8 \%$

Abundant: $13.4 \%$

\section{Water Chemistry:}

\section{All Sites}

Mean pH: 8.8 (range: $7.5-10.7$ )

Mean conductivity: $1.99 \mathrm{mS}$ (range: $0.24-30.30$ )

\section{Sites With Live Specimens}

Mean pH: 8.9 (range: 7.7-9.5)

Mean conductivity: $0.48 \mathrm{mS}$ (range: $0.24-0.77$ )

\begin{tabular}{ccc}
\hline Type & $\begin{array}{c}\% \text { of occupied } \\
\text { sites }\end{array}$ & $\begin{array}{c}\text { Relative to } \\
\text { availability }\end{array}$ \\
\hline River & $11.9 \%$ & $-27.0 \%$ \\
Lake & $40.3 \%$ & $+18.5 \%$ \\
Creek & $17.9 \%$ & $-17.9 \%$ \\
Pond & $29.9 \%$ & $+7.2 \%$ \\
\hline
\end{tabular}




\section{Helisoma anceps anceps}

Two-ridge rams-horn

\section{Current Status: Sensitive}

Helisoma anceps anceps is identified by its planospiral dextral coiling, large aperture, and deeply immersed umbilicus and spire (Clarke 1981). The most unique characteristic of this species is the prominent carinae present on the upper and lower surfaces of the body whorl (Clarke 1981). In addition, the apex is immersed rather than smoothsided, and the aperture is sharply pointed above and below.

H. a. anceps has a wide distribution in North America. It occurs from southern Quebec to eastern British Columbia, extending north to the tree line and south into Georgia and northwestern Mexico (Clarke 1981). The species typically lives among vegetation in lakes, ponds, rivers and streams, and is absent from temporary waterbodies (Clarke 1981). In British Columbia, it occurs in the eastern part of the province and is listed as "secure" (Lee 2000). In Alberta, the species has been found in all natural regions of the province, although records are relatively sparse (Lepitzki 2001). It is suspected to occur in more locations than indicated by current records (Lepitzki 2001).

We found specimens of $H$. a. anceps at 5 locations (2.5\% of sampled sites) in the Central Parkland Subregion, with live specimens being found at 2 sites $(1.0 \%)$. Most locations were on the extreme western edge of the Subregion, and in the adjacent Dry Mixedwood Subregion. However, one location was on the Saskatchewan border. The species occurred most frequently in creeks and lakes. H. a. anceps was most often observed to be "uncommon" or "common" (2-100 individuals) where it occurred, with a maximum of 34 specimens being found at a site. Living specimens were found over a $\mathrm{pH}$ range of 8.6 to 9.2 , and at relatively low conductivities of 0.24 to $0.41 \mathrm{mS}$.

Helisoma anceps anceps appears to have a sparse distribution in central Alberta. In addition, it occurs at relatively low abundance and lives in a fairly narrow range of water conditions. The current designation of "Sensitive" may be appropriate for this species. 


\section{Menetus opercularis}

Button sprite
Current Status: May Be At Risk

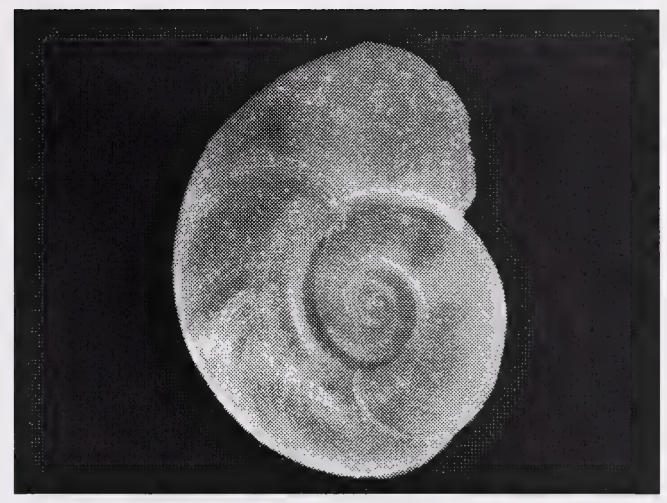

Menetus opercularis is similar to Promenetus exacuous in having a small shell size $(<8 \mathrm{~mm}$ in diameter), dextral planospiral coiling, flat spire and a prominent keel on body whorl (Clarke 1981; referred to as Menetus cooperi). However, $M$. opercularis differs in having the keel located high up on the body whorl (rather than at the middle), and the apex is slightly sunken.

M. opercularis has a scattered distribution across North America, occurring from southern Alaska to east-central Alberta (Clarke 1981). The species lives among vegetation in perennial waterbodies such as lakes, ponds and slow-moving portions of rivers and streams (Clarke 1981). In British Columbia, the species is found throughout Vancouver Island and the western region of the province to a northern limit of $56^{\circ} \mathrm{N}$. It is listed as being "secure" in that province (Lee 2000). In Alberta, M. opercularis has been found at only a few locations in the Parkland region (Lepitzki 2001).

Surveys in the Central Parkland Subregion show that this species has a relatively broad distribution, and a more common occurrence than previously thought. The species was collected from $18(9.1 \%)$ sites sampled. It was especially well represented in lakes, and relatively rare in rivers and creeks. At the locations where it was found, the species was most often described as being "rare" or "uncommon" (1-10 individuals), but was occasionally found to be "abundant" (maximum of 282 specimens at a site). Living specimens were found over a $\mathrm{pH}$ range of 7.8 to 9.5 , and conductivities of 0.5 to $6.5 \mathrm{mS}$. Compared to other species, $M$. opercularis is fairly tolerant of high conductivities (Table 3).

Menetus opercularis has a fairly broad distribution in the Central Parkland Subregion of Alberta, and can be locally abundant. Given this, the species' status may warrant revision from the current designation of "May Be At Risk".

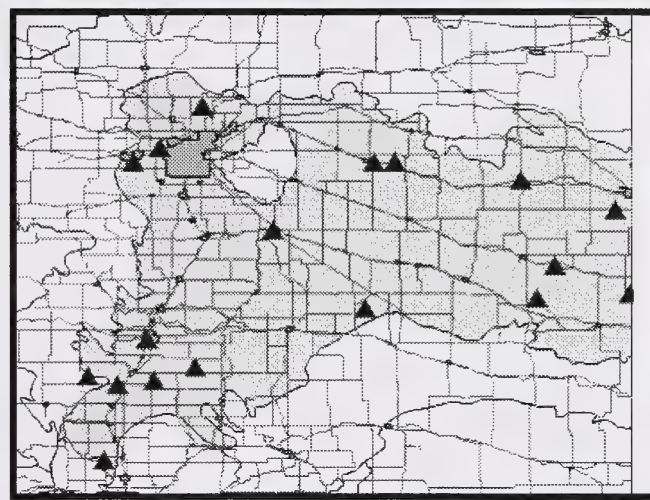

\section{Characteristics}

Present at $18(9.1 \%)$ of 197 sites Alive at $7(3.6 \%)$ of 197 sites

\begin{tabular}{ccc}
\multicolumn{3}{c}{ Wetland Use: } \\
\hline Type & $\begin{array}{c}\% \text { of occupied } \\
\text { sites }\end{array}$ & $\begin{array}{c}\text { Relative to } \\
\text { availability }\end{array}$ \\
\hline River & $5.6 \%$ & $-65.6 \%$ \\
Lake & $55.6 \%$ & $+63.5 \%$ \\
Creek & $11.1 \%$ & $-49.1 \%$ \\
Pond & $27.8 \%$ & $-0.4 \%$ \\
\hline
\end{tabular}

Abundance:

Mean \#/sample: 26.9 (range: 1-282)
Rare: $38.9 \%$

Uncommon: $44.4 \%$

Common: $5.6 \%$ Abundant: $11.1 \%$

Water Chemistry:

\section{All Sites}

Mean pH: 8.9 (range: $7.8-9.5$ )

Mean conductivity: $1.17 \mathrm{mS}$ (range: $0.24-6.50$ )

\section{Sites With Live Specimens}

Mean pH: 8.8 (range: $7.8-9.5$ )

Mean conductivity: $1.55 \mathrm{mS}$ (range: $0.45-6.50$ ) 


\section{Planorbella binneyi}

Coarse rams-horn

\section{Current Status: Undetermined}

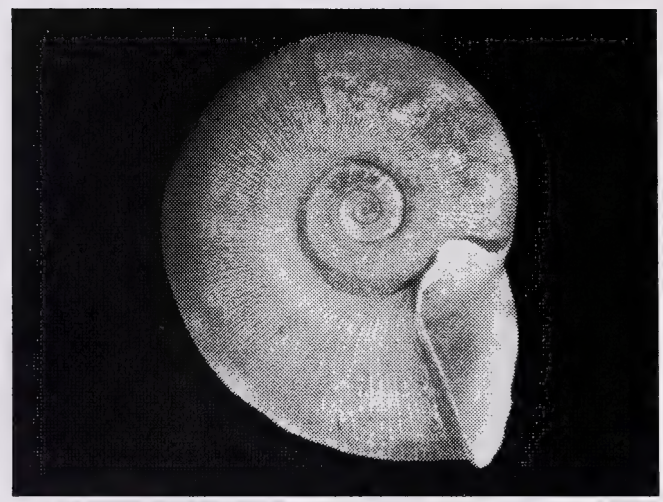

Planorbella binneyi strongly resembles $P$. subcrenata. In fact, Clarke (1981) considered these species to be subspecies of Helisoma trivolis $(H . t$. binneyi and $H$. t. subcrenatum). Both species have large solid shells, sinistral coiling, a deep umbilicus and large, expanded ear-shaped apertures. Populations of the two species have been reported to intergrade, especially in western Alberta where their ranges overlap (Clarke 1981). As a rule, $P$. binneyi can be distinguished by its greater shell height (>10 mm), a more broadly expanded aperture, and a body whorl that is higher than the penultimate whorl (Clarke 1981)

P. binneyi has a limited distribution, occurring principally in western Alberta and in the Pacific drainage from southern British Columbia to California (Clarke 1981). The species has been found in eutrophic, well-vegetated lakes, although specific ecological information is scarce (Clarke 1981). In British Columbia the species is uncommon south of $55^{\circ} \mathrm{N}$ and is listed as "vulnerable/apparently secure" (Lee 2000). In Alberta, $P$. binneyi has been found at only a few locations in the Rocky Mountains and Boreal Forest Natural Regions (Lepitzki 2001).

Surveys in the Central Parkland Subregion confirm the presence of this species. Shells were found at 2 $(1.0 \%)$ sites: Wabamum Lake west of Edmonton (actually in the Boreal Forest Natural Region), and in a pond east of Strome. No living specimens were found at these sites, where the $\mathrm{pH}$ ranged from 8.4 to 9.0 , and the conductivity from 0.50 to $1.67 \mathrm{mS}$. At the locations where it was found, the species was observed to be "rare" or "uncommon" (1-10 individuals), with a maximum of 4 individuals being found.

Planorbella binneyi has a very limited distribution in the Central Parkland Subregion of Alberta. Where it is found, it occurs at low abundance. The paucity of specimens might be explained by the fact that central Alberta is at the eastern periphery of the species' range, where populations are thought to intergrade with those of $P$. subcrenata (Clarke 1981).

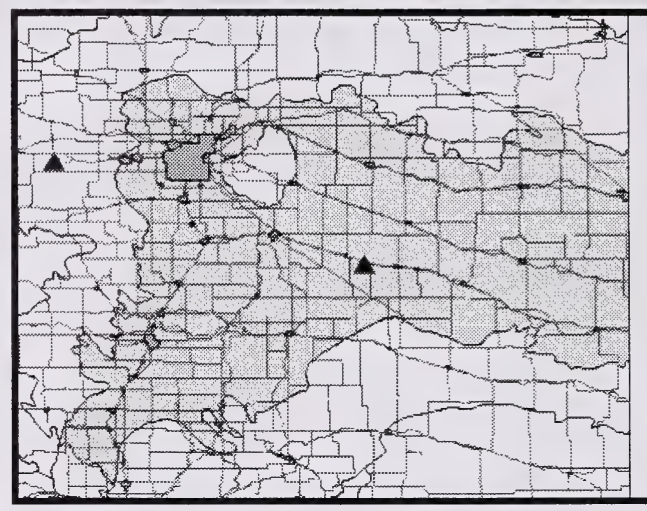

\section{Characteristics}

Present at $2(1.0 \%)$ of 197 sites Alive at $0(0.0 \%)$ of 197 sites

Wetland Use:

\begin{tabular}{ccc}
\hline Type & $\begin{array}{c}\% \text { of occupied } \\
\text { sites }\end{array}$ & $\begin{array}{c}\text { Relative to } \\
\text { availability }\end{array}$ \\
\hline River & $0.0 \%$ & $-100.0 \%$ \\
Lake & $50.0 \%$ & $+47.1 \%$ \\
Creek & $0.0 \%$ & $-100.0 \%$ \\
Pond & $50.0 \%$ & $+79.2 \%$ \\
\hline
\end{tabular}

Abundance:

Mean \#/sample: 2.5 (range: 1-4)
Rare: $50.0 \%$

Uncommon: $50.0 \%$

Common: $0.0 \%$ Abundant: $0.0 \%$

\section{Water Chemistry:}

\section{All Sites}

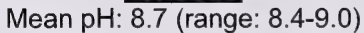

Mean conductivity: $1.09 \mathrm{mS}$ (range: $0.50-1.67$ )

\section{Sites With Live Specimens}

Mean $\mathrm{pH}$ : N/A

Mean conductivity: N/A 


\section{Planorbella pilsbryi infracarinatum}

Greater carinate rams-horn

Current Status: Undetermined

Planorbella pilsbryi infracarinatum is identified by the large thick shell, planospiral sinistral coiling, and deep umbilicus (Clarke 1981; referred to as Helisoma pilsbryi infracarinatum). The species strongly resembles $P$. subcrenata but differs by the presence of a prominent carina on the upper body whorl and the depressed, smooth-sided bowl-like apex (Burch 1989). Although this subspecies is considered to be distinct in this study, it should be recognized that there is considerable debate about the taxonomy of this, and closely related species. Burch (1989) suspected that $P$. pilsbryi is not taxonomically distinct from $P$. trivolvis.

$P . p$. infracarinatum is described as a boreal species that occurs from southern Quebec and Ontario to east-central Alberta (Clarke 1981). The species is most frequently found among vegetation in lakes, ponds, or quiet backwaters of streams (Clarke 1981). The species has not been recorded in British Columbia (Lee 2000). In Alberta, P. p. infracarinatum has previously been found at only a single location, in the Boreal Forest Natural Region at Lac La Biche (Clarke 1981, Lepitzki 2001).

The present study confirms the species' occurrence in Central Parkland Subregion of Alberta. P. $p$. infracarinatum was collected from $3(1.5 \%)$ sites sampled. All sites were along the mainstem of the Battle River, including two lotic sites, and in Driedmeat Lake. At the locations where it was found, the species was observed to be "rare" or "uncommon" (1-10 individuals), with a maximum of 8 individuals being found. The site where living specimens were collected had a $\mathrm{pH}$ of 9.9 , and a conductivity of $0.64 \mathrm{mS}$.

This study found a southwesterly range extension of Planorbella pilsbryi infracarinatum from the previously known site at Lac La Biche. However the species evidently has a very limited distribution in the Central Parkland Subregion, and occurs at low abundance. The species must therefore be considered to be rare in central Alberta.
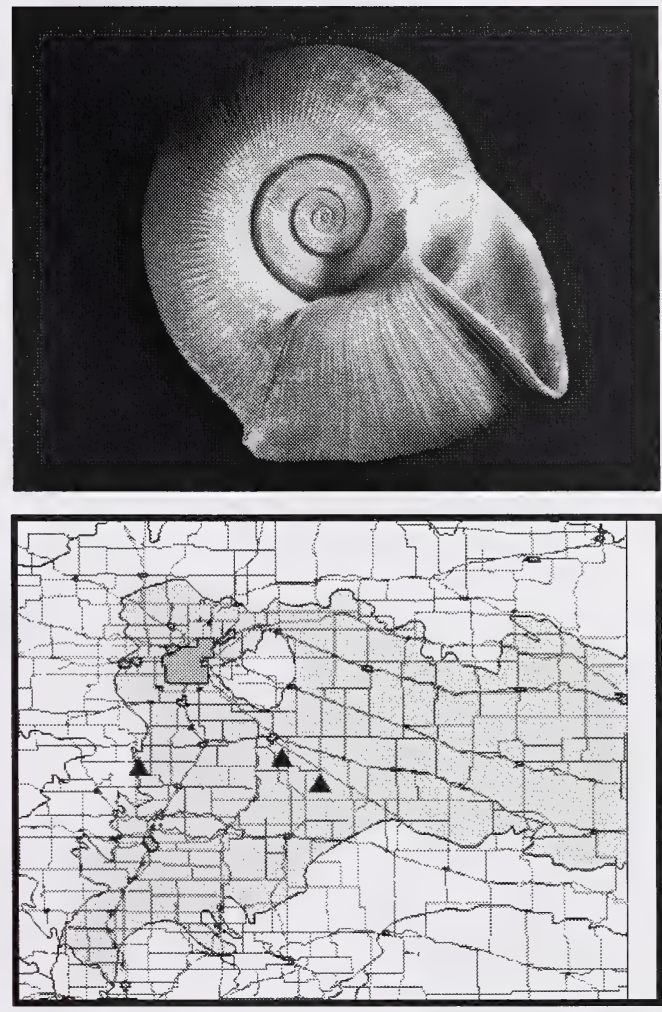

\section{Characteristics}

Present at $3(1.5 \%)$ of 197 sites Alive at $1(0.5 \%)$ of 197 sites

Wetland Use:

\begin{tabular}{ccc}
\hline Type & $\begin{array}{c}\% \text { of occupied } \\
\text { sites }\end{array}$ & $\begin{array}{c}\text { Relative to } \\
\text { availability }\end{array}$ \\
\hline River & $66.7 \%$ & $+309.2 \%$ \\
Lake & $33.3 \%$ & $-2.1 \%$ \\
Creek & $0.0 \%$ & $-100.0 \%$ \\
Pond & $0.0 \%$ & $-100.0 \%$ \\
\hline
\end{tabular}

\section{Abundance:}

Mean \#/sample: 4.0 (range: $1-8$ )

Rare: $33.3 \%$

Common: $0.0 \%$

Uncommon: $66.7 \%$ Abundant: $0.0 \%$

\section{Water Chemistry:}

\section{All Sites}

Mean pH: 8.8 (range: 8.1-9.9)

Mean conductivity: $0.50 \mathrm{mS}$ (range: $0.41-0.64$ )

\section{Sites With Live Specimens}

Mean pH: 9.9 (range: N/A)

Mean conductivity: $0.64 \mathrm{mS}$ (range: N/A) 


\section{Planorbella subcrenata}

Rough rams-horn

\section{Current Status: Secure}

Planorbella subcrenata can be easily identified by its large and solid shell, sinistral planorbid coiling, large ear-shaped aperture, deep umbilicus and lack of prominent carinae on the body whorl (Clarke 1981; referred to as Helisoma trivolvis subcrenatum). $P$. subcrenata strongly resembles $P$. binneyi (referred to as $H$. $t$. binneyi) and populations of the two species have been reported to intergrade in western Alberta (Clarke 1981). $P$. subcrenata can be differentiated by the smaller shell size (height not exceeding 10 $\mathrm{mm}$ ), and looser irregular coiling (Clarke 1981). However, some authorities (e.g. Burch 1989) have recognized taxonomic and identification issues within the Planorbella genus that require clarification.

$P$. subcrenata occurs primarily in western North America, from the Yukon Territory to Manitoba and south to California and Utah. It is described as being common throughout its range (Clarke 1981). The species occurs in most perennial waterbodies that support rooted vegetation (Clarke 1981). $P$. subcrenata is one of the most frequently encountered species in southern Manitoba, and is described as being tolerant of a wide range of water conditions (Pip 2000). The species occurs throughout British Columbia, and is listed as "secure" in that province (Lee 2000). P. subcrenata has been reported from all natural regions of Alberta (Lepitzki 2001).

Surveys in the Central Parkland Subregion confirm this species' broad distribution and common occurrence. $P$. subcrenata was collected from 93 $(47.2 \%)$ sites sampled, which was the second highest frequency of occurrence among all species encountered in this inventory (Table 2). It was found in a wide range of aquatic habitats (but most commonly in creeks and ponds). At the locations where it was found the species was most often observed to be "uncommon" or "common" (2-100 individuals). Living specimens were found over a $\mathrm{pH}$ range of 7.0 to 10.7 , and conductivities of 0.31 to $8.65 \mathrm{mS}$. These ranges are among the highest of all species encountered in this study (Table 3 ).

With its broad distribution, relatively high abundance, and tolerance to a wide range of water conditions, Planorbella subcrenata is apparently a "Secure" species in Alberta's Central Parkland Subregion.
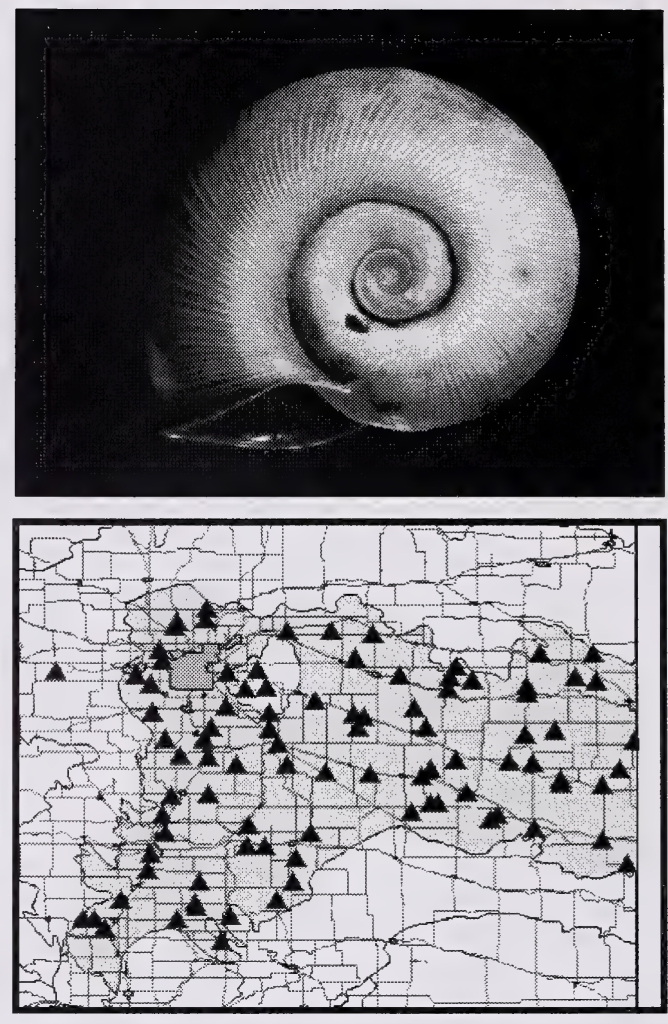

\section{$\underline{\text { Characteristics }}$}

Present at $93(47.2 \%)$ of 197 sites Alive at $44(22.3 \%)$ of 197 sites

Wetland Use:

\begin{tabular}{ccc}
\hline Type & $\begin{array}{c}\% \text { of occupied } \\
\text { sites }\end{array}$ & $\begin{array}{c}\text { Relative to } \\
\text { availability }\end{array}$ \\
\hline River & $7.5 \%$ & $-54.0 \%$ \\
Lake & $28.0 \%$ & $-17.6 \%$ \\
Creek & $31.2 \%$ & $+43.1 \%$ \\
Pond & $33.3 \%$ & $+19.4 \%$ \\
\hline
\end{tabular}

\section{Abundance:}

Mean \#/sample: 13.4 (range 1-107)

Rare: $9.7 \%$

Uncommon: $57.0 \%$

Common: $32.3 \%$ Abundant: $1.1 \%$

\section{Water Chemistry:}

\section{All Sites}

Mean pH: 8.7 (range: $7.0-10.7$ )

Mean conductivity: $1.47 \mathrm{mS}$ (range: $0.27-8.78$ )

\section{Sites With Live Specimens}

Mean pH: 8.6 (range: $7.0-10.7$ )

Mean conductivity: $1.33 \mathrm{mS}$ (range: $0.31-8.65$ ) 


\section{Planorbella campanulata}

Bellmouth rams-horn

\section{Current Status: Not Recorded in Alberta}

Planorbella campanulata is easily distinguished by the planospiral sinistral coiling, flat or slightly raised spire, compressed whorls, and distinct bell-shaped aperture (Clarke 1981; referred to as Helisoma campanulatum campanulatum). Adult shells lack carinae and are smaller than other Planorbella species (typically $<15 \mathrm{~mm}$ wide and $<6 \mathrm{~mm}$ high). Live individuals can be identified by the reddish brown or blackish color of the animal and their slowmoving nature (Clarke 1981).

According to Clarke (1981), P. campanulata is distributed from Newfoundland through southern Quebec and into central Saskatchewan. It is described as being "common" throughout its range. In the United States it occurs from interior New Jersey and New York to Vermont and westward to Michigan (Emerson and Jacobson 1976). The species has not previously been recorded in British Columbia or Alberta (Clarke 1981, Lee 2000, Lepitzki 2001). P. campanulata occurs in vegetated still-water habitats such as ponds and lakes, as well as slowmoving or backwater areas of rivers (Clarke 1981). In southern Manitoba, the species was observed to be one of the few species that has increased in occurrence in recent years (Pip 2000).

Surveys in the Central Parkland Subregion produced the first record for this species in the province. $P$. campanulata was collected from a single site $(0.5 \%)$, an unnamed wetland approximately $10 \mathrm{~km}$ southwest of Edmonton. At this location, the species was observed to be "common" (17 individuals, including live specimens). The site had a $\mathrm{pH}$ of 8.1 , and a conductivity of $0.43 \mathrm{mS}$.

It is unclear whether Planorbella campanulata is a recent arrival to the province, or whether it was present but previously undetected. Regardless, the species is apparently rare and localized in the region. Planorbella campanulata was found only in the extreme northwest part of the subregion, and future collections in the adjacent Dry Mixedwood Subregion (Boreal Forest Natural Region) to the north and west will be required to clarify the species' status in the province.
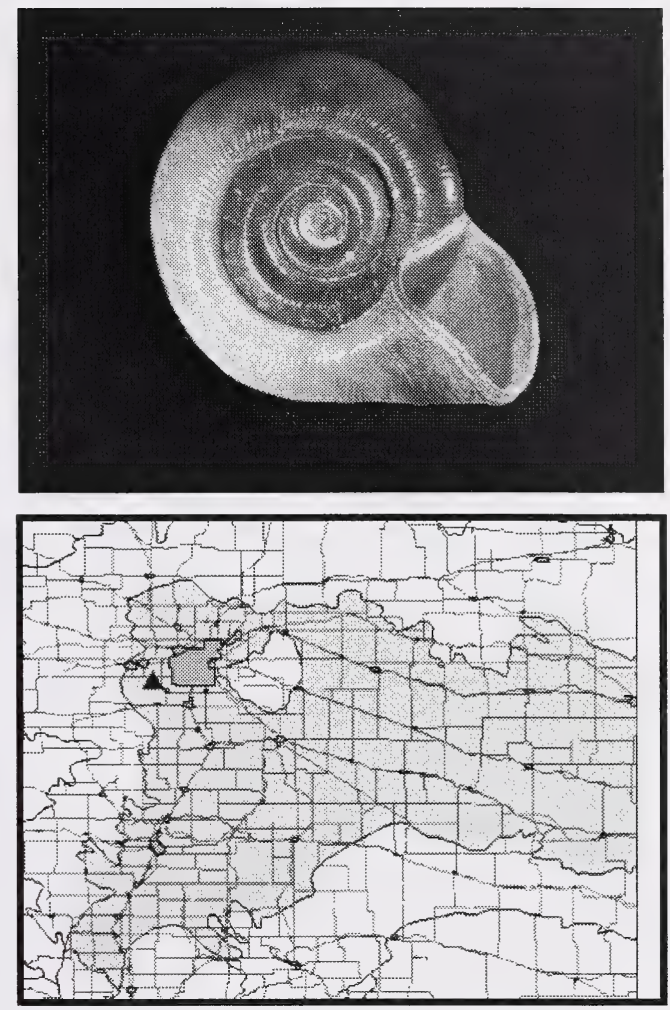

\section{Characteristics}

Present at $1(0.5 \%)$ of 197 sites Alive at $1(0.5 \%)$ of 197 sites

Wetland Use:

\begin{tabular}{lcc}
\hline Type & $\begin{array}{c}\% \text { of occupied } \\
\text { sites }\end{array}$ & $\begin{array}{c}\text { Relative to } \\
\text { availability }\end{array}$ \\
\hline River & $0 \%$ & $-100.0 \%$ \\
Lake & $0 \%$ & $-100.0 \%$ \\
Creek & $0 \%$ & $-100.0 \%$ \\
Pond & $100.0 \%$ & $+258.4 \%$ \\
\hline
\end{tabular}

Abundance:

Mean \#/sample: 17 (range: N/A)

Rare: $0.0 \%$ Uncommon: $0.0 \%$ Abundant: $0.0 \%$

\section{Water Chemistry:}

\section{All Sites}

Mean $\mathrm{pH}: 8.1$ (range: N/A)

Mean conductivity: $0.43 \mathrm{mS}$ (range: N/A)

\section{Sites With Live Specimens}

Mean $\mathrm{pH}: 8.1$ (range: N/A)

Mean conductivity: $0.43 \mathrm{mS}$ (range: N/A) 


\section{Planorbula armigera}

Thicklip rams-horn

\section{Current Status: Sensitive}

Planorbula armigera is identified by the planospiral dextral coiling, flat spire, numerous whorls and deep, funnel shaped umbilicus (Clarke 1981). The most unique characteristic of this species is the presence of denticles (teeth-like projections), located inside the aperture of adults and juveniles (Clarke 1981). In addition, the shells of adults reach a maximum diameter of $8 \mathrm{~mm}$ and the last part of body whorl is expanded and deflected downwards (Clarke 1981).

$P$. armigera has a broad distribution across Canada, from New Brunswick to northeastern British Columbia, and north to the tree line (Clarke 1981). The species is abundant in subarctic muskeg but uncommon in rest of its range (Clarke 1981). In southern Manitoba, $P$. armigera has been reported to be one of the species that is declining dramatically (Pip 2000). In British Columbia, it is known to occur only in the far northeastern part of the province and is listed as being "rare or uncommon" (Lee 2000). In Alberta, $P$. armigera has been previously found at several sites in the northern two-thirds of the province, specifically the Foothills, Parkland and Boreal Forest Natural Regions (Lepitzki 2001).

$P$. armigera has a limited distribution in the Central Parkland Subregion. The species was collected from $2(1.0 \%)$ widely separated sites in the region. Both sites were ponds. At the few locations where this species was found, it was observed to be "rare" or "uncommon" (1-10 individuals), with no more than 2 individuals being found at a site. Living specimens were not found, but $P$. armigera shells were found over a pH range of 7.7 to 9.0 , and conductivities of 0.43 to $16.28 \mathrm{mS}$.

It is evident that Planorbula armigera is a sparsely distributed and uncommon species in Central Parkland Subregion. However, central Alberta is apparently at the southern edge of its range in the province, and the species is likely to be more common further north. 


\section{Planorbula campestris}

Meadow rams-horn

\section{Current Status: Sensitive}

Planorbula campestris is the larger of the two Planorbula species found in Alberta. This species can be easily recognized by the many, slowly increasing whorls, planospiral dextral coiling, flat spire, and funnel-shaped umbilicus (Clarke 1981). Unlike $P$. armigera, the adult stage of $P$. campestris does not have denticles, and the shell reaches a greater maximum diameter (>8 $\mathrm{mm}$ ).

P. campestris has a broad distribution in western North America, occurring from southern Manitoba to northern Alberta and south through the United States to Utah and New Mexico. Isolated populations are also known from Vancouver Island and southwestern Yukon (Clarke 1981). The species is associated with highly vegetated vernal ponds, swamps and springflooded areas of permanent waterbodies (Clarke 1981). Studies done in southern Manitoba in the 1970 s reported $P$. campestris to be rare, and further research carried out in 1989 failed to recover the species in the same region (Pip 2000). In British Columbia, the species occurs occasionally in the southern and eastern regions of the province and is listed as being "apparently secure" (Lee 2000). In Alberta, $P$. campestris has been found throughout the province in all natural regions except the Canadian Shield (Lepitzki 2001).

Surveys in the Central Parkland Subregion found $P$. campestris to be sparsely distributed and of low abundance. The species was collected from 5 (2.5\%) sites in the southwestern and north-central parts of the region. All of these sites were ponds. In four of five sites, the species was found to be "rare", with only a single specimen being found. Living specimens were only found at one site. At this location, the $\mathrm{pH}$ was measured as 7.7, and the conductivity as $0.66 \mathrm{mS}$.

Planorbula campestris is an sparsely distributed and uncommon species in the Central Parkland Subregion of Alberta.
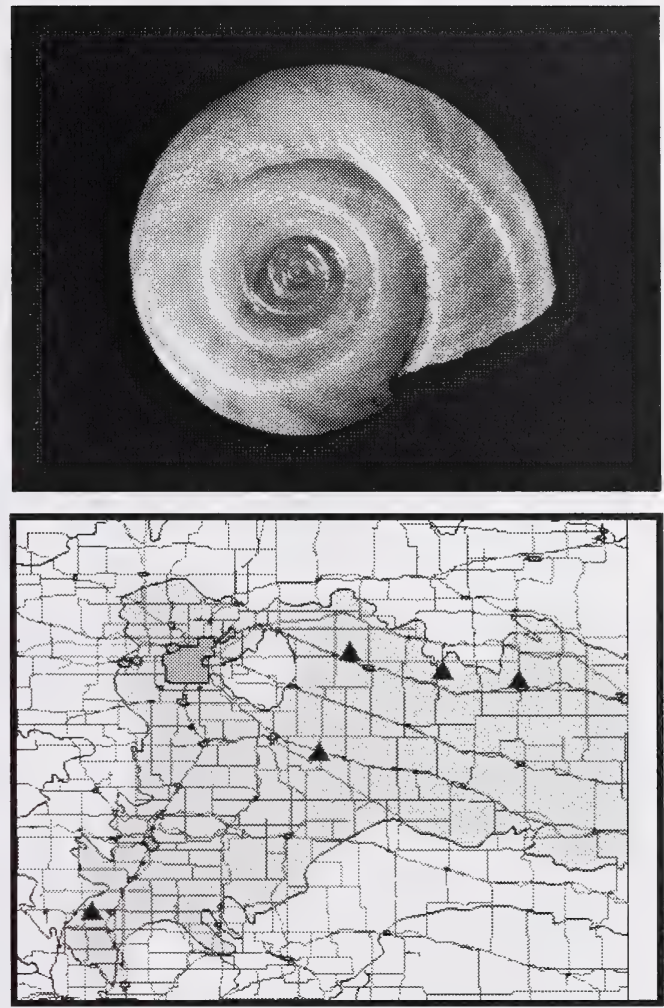

\section{Characteristics}

Present at $5(2.5 \%)$ of 197 sites Alive at $1(0.5 \%)$ of 197 sites

\begin{tabular}{ccc}
\multicolumn{2}{c}{ Wetland Use: } \\
\hline Type & $\begin{array}{c}\% \text { of occupied } \\
\text { sites }\end{array}$ & $\begin{array}{c}\text { Relative to } \\
\text { availability }\end{array}$ \\
\hline River & $0.0 \%$ & $-100.0 \%$ \\
Lake & $0.0 \%$ & $-100.0 \%$ \\
Creek & $0.0 \%$ & $-100.0 \%$ \\
Pond & $100.0 \%$ & $+258.4 \%$ \\
\hline
\end{tabular}

\section{Abundance:}

Mean \#/sample: 1.6 (range: $1-4$ )

Rare: $80.0 \%$

Common: $0.0 \%$

Uncommon: $20.0 \%$ Abundant: $0.0 \%$

\section{Water Chemistry:}

\section{All Sites}

Mean pH: 8.0 (range: $7.6-8.6$ )

Mean conductivity: $1.59 \mathrm{mS}$ (range: $0.66-3.01$ )

\section{Sites With Live Specimens}

Mean pH: 7.7 (range: N/A)

Mean conductivity: $0.66 \mathrm{mS}$ (range: N/A) 


\section{Promenetus exacuous exacuous}

Keeled promenetus

\section{Current Status: Secure}

Promenetus exacuous exacuous is recognized by its small size, planospiral dextral coiling, rather flat spire, and rapidly expanding whorls. $P$. e. exacuous can be differentiated from $M$. opercularis by the prominent keel located centrally on the body whorl (Clarke 1981). Turgeon et al. (1998) and Burch (1989) did not recognize subspecies of $P$. exacuous. Clarke $(1973,1981)$ distinguishes between $P$. e. exacuous and $P$. e. megas based on shell morphology and geographic distribution (megas replacing exacuous in most localities on the western prairies), remarking that exacuous adults have a smaller shell diameter $(4-6 \mathrm{~mm})$ than megas $(6-9$ $\mathrm{mm}$ ). In the current study, shell size was used to distinguish between subspecies.

$P$. e. exacuous has a broad distribution across North America from Nova Scotia to eastern British Columbia. In the United States, it occurs in Alaska and east of the Rocky Mountains. It is described as being a "common" species (Clarke 1981). The species is known to live in a variety of temporary and permanent waterbodies where submersed vegetation is present (Clarke 1981). In southern Manitoba, Promenetus exacuous has been reported as one of the species that is drastically declining (Pip 2000). In British Columbia, P. e. exacuous occurs widely throughout the province, except in the southwestern region, and is listed as being "relatively secure" or "secure" (Lee 2000). In Alberta, P. e. exacuous has been found at numerous locations in all natural regions of the province (Lepitzki 2001).

Surveys in the Central Parkland Subregion confirm this subspecies' broad distribution and relatively high abundance. $P$. e. exacuous was collected from 45 $(22.8 \%)$ sites sampled, and in a wide range of habitats. At the locations where it was found, the species was most often observed to be "uncommon" (2-10 individuals), but was occasionally considered to be "abundant" (maximum of 842 specimens). Living animals were found over a $\mathrm{pH}$ range of 7.5 to 10.7 , and conductivities of 0.47 to $1.45 \mathrm{mS}$.

Promenetus exacuous exacuous is a common and widespread species in the Central Parkland Subregion, and should be considered to be "Secure".
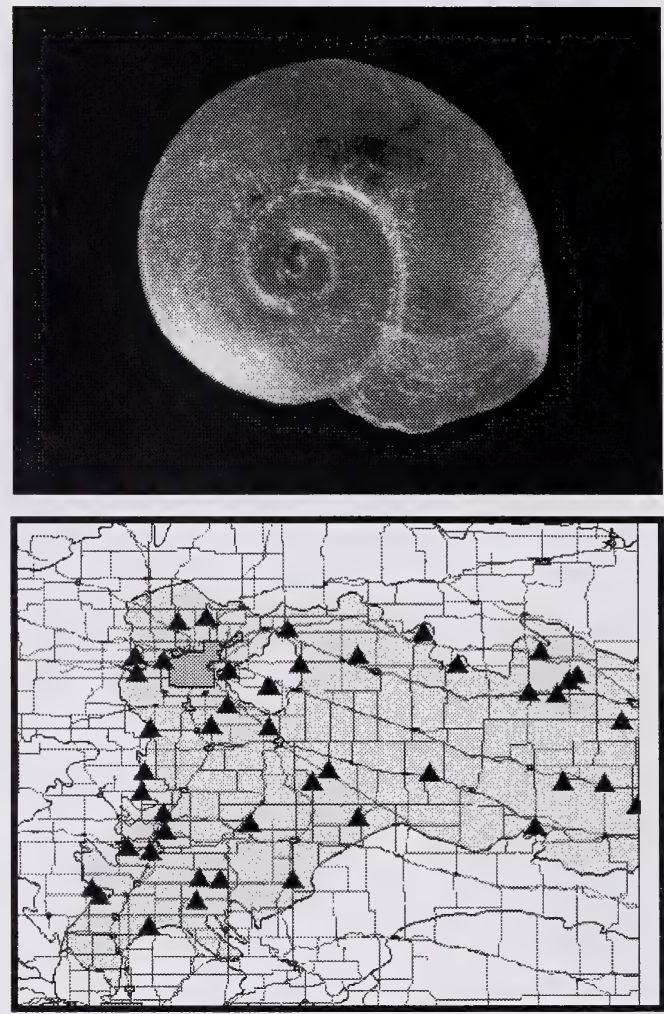

\section{Characteristics}

Present at $45(22.8 \%)$ of 197 sites Alive at $13(6.6 \%)$ of 197 sites

Wetland Use:

\begin{tabular}{ccc}
\hline Type & $\begin{array}{c}\% \text { of occupied } \\
\text { sites }\end{array}$ & $\begin{array}{c}\text { Relative to } \\
\text { availability }\end{array}$ \\
\hline River & $13.3 \%$ & $-18.4 \%$ \\
Lake & $37.8 \%$ & $+11.2 \%$ \\
Creek & $24.4 \%$ & $+11.9 \%$ \\
Pond & $24.4 \%$ & $-12.5 \%$ \\
\hline
\end{tabular}

\section{Abundance:}

Mean \#/sample: 28.2 (range: 1-842)

Rare: $13.3 \%$

Uncommon: $66.7 \%$

Common: $17.8 \%$ Abundant: $2.2 \%$

\section{Water Chemistry:}

\section{All Sites}

Mean pH: 8.6 (range: $7.5-10.7$ )

Mean conductivity: $1.08 \mathrm{mS}$ (range: $0.24-6.87$ )

\section{Sites With Live Specimens}

Mean pH: 8.5 (range: $7.5-10.7$ )

Mean conductivity: $0.93 \mathrm{mS}$ (range: $0.47-1.45$ ) 


\section{Promenetus exacuous megas}

Broad promenetus

\section{Current Status: Sensitive}

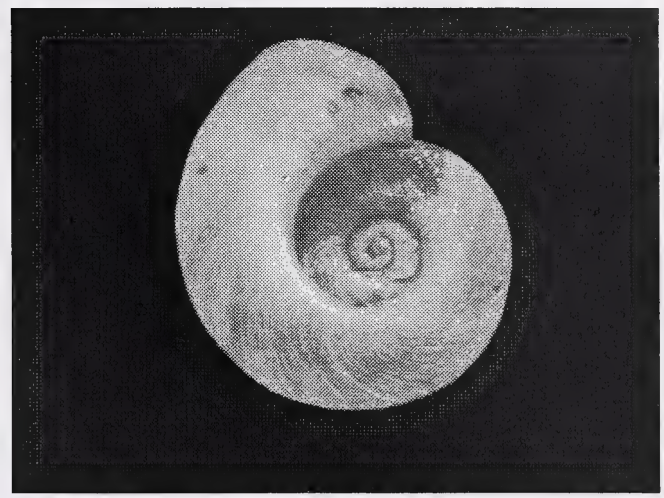

Promenetus exacuous megas is similar to $P$. e. exacuous and can be identified by the same general features: small size, planospiral dextral coiling, rapidly increasing whorls and prominent keel located centrally on the body whorl. Turgeon et al. (1998) and Burch (1989) do not recognize subspecies of $P$. exacuous. However, Clarke (1973, 1981) distinguishes between the two subspecies, describing $P$. e. megas as having a larger $(6-9 \mathrm{~mm}$ wide), heavier shell with a more prominent pinched peripheral keel. In this study, shell diameter was chosen as the characteristic differentiating these two subspecies.

$P$. e. megas occurs in the prairie provinces of Canada, extending from southeastern Manitoba to southeastern British Columbia and into the adjacent parts of the United States (Clarke 1981). The species is found in a wide range of aquatic habitats such as lakes, ponds, streams, ditches and swamps (Clarke 1981). In British Columbia, the species has been collected from only one site and its distribution is uncertain (Lee 2000). In Alberta, P. e. megas has been collected from all natural regions except the Canadian Shield (Lepitzki 2001).

Surveys in the Central Parkland Subregion suggest a limited distribution in central Alberta. $P$. e. megas was collected from $4(2.0 \%)$ sites sampled, and was only found in lakes and creeks in the western half of the study area. At the locations where it was found, the species was most often observed to be "uncommon" (2-10 individuals), with no more than 20 specimens being identified at a site. Living animals were found over a $\mathrm{pH}$ range of 7.5 to 7.8 , and conductivities of 0.82 to $1.30 \mathrm{mS}$.

Promenetus exacuous megas appears to be an uncommon subspecies with a limited distribution in the Central Parkland Subregion of Alberta. However, we acknowledge that its abundance and distribution might be underestimated, given that smaller $(<6 \mathrm{~mm})$ juveniles would have been recorded as the smaller subspecies, $P$. e. exacuous.

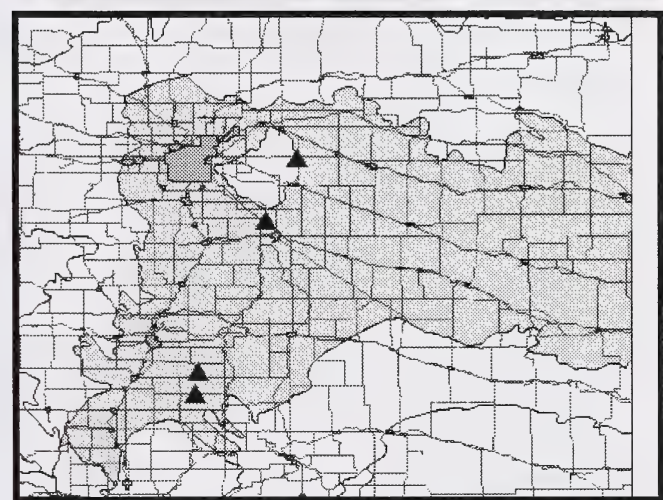

\section{Characteristics}

Present at $4(2.0 \%)$ of 197 sites Alive at $2(1.0 \%)$ of 197 sites

Wetland Use:

\begin{tabular}{lcc}
\hline Type & $\begin{array}{c}\% \text { of occupied } \\
\text { sites }\end{array}$ & $\begin{array}{c}\text { Relative to } \\
\text { availability }\end{array}$ \\
\hline River & $0.0 \%$ & $-100.0 \%$ \\
Lake & $50.0 \%$ & $+47.1 \%$ \\
Creek & $50.0 \%$ & $+129.4 \%$ \\
Pond & $0.0 \%$ & $-100.0 \%$ \\
\hline
\end{tabular}

\section{Abundance:}

Mean \#/sample: 7.3 (range: 1-20)

Rare: $25.0 \%$

Uncommon: $50.0 \%$

Common: $25.0 \%$

Abundant: $0.0 \%$

\section{Water Chemistry:}

\section{All Sites}

Mean pH: 8.5 (range: $7.5-9.4$ )

Mean conductivity: $1.00 \mathrm{mS}$ (range: $0.80-1.30$ )

\section{Sites With Live Specimens}

Mean pH: 7.7 (range: $7.5-7.8$ )

Mean conductivity: $1.06 \mathrm{mS}$ (range: $0.82-1.30$ ) 


\section{Promenetus umbilicatellus}

Umbilicate sprite

\section{Current Status: Sensitive}

Promenetus umbilicatellus can be distinguished from the other planorbid snails by its small size (diameter $\leq 5 \mathrm{~mm}$ ), thin and fragile shell, rounded whorls, and prominent deep umbilicus (Clarke 1981). In addition, the spire is flattened, with the first two whorls slightly immersed. Unlike other members of its genus, this species lacks a peripheral keel and the umbilicus is funnel-shaped.

P. umbilicatellus is primarily a "prairie species" being found from southern Manitoba to central Alberta and southern British Columbia. In the United States, the species occurs as far south as New Mexico. It is described as being "rather uncommon" throughout this range (Clarke 1981). The species is associated with vegetated vernal ponds, marshes, and intermittent streams (Clarke 1981). Studies done in southern Manitoba in the 1970 s reported $P$. umbilicatellus as being rare, but subsequent research conducted in 1998 failed to find this species in the same areas (Pip 2000). In British Columbia, the species is found at few locations and is uncommon (Lee 2000). In Alberta, P. umbilicatellus has been reported from a variety of sites, mainly in southern two-thirds of the province. It has been recorded in all natural regions, with the exception of the Canadian Shield (Lepitzki 2001).

Surveys in the Central Parkland Subregion found $P$. umbilicatellus to be rare. The species was collected from only $3(1.5 \%)$ widely separated sites, all in creek habitats. At the locations where it was found, the species was observed to be "rare" or "uncommon" (1-10 individuals), with no more than 2 individuals being found at any site. Living specimens were found over a pH range of 7.4 to 7.8 , and conductivities of 0.82 to $1.62 \mathrm{mS}$.

Promenetus umbilicatellus is evidently a sparsely distributed and uncommon species in the Central Parkland Subregion of Alberta. Limited observations also suggest that the species is restricted to creek habitats.
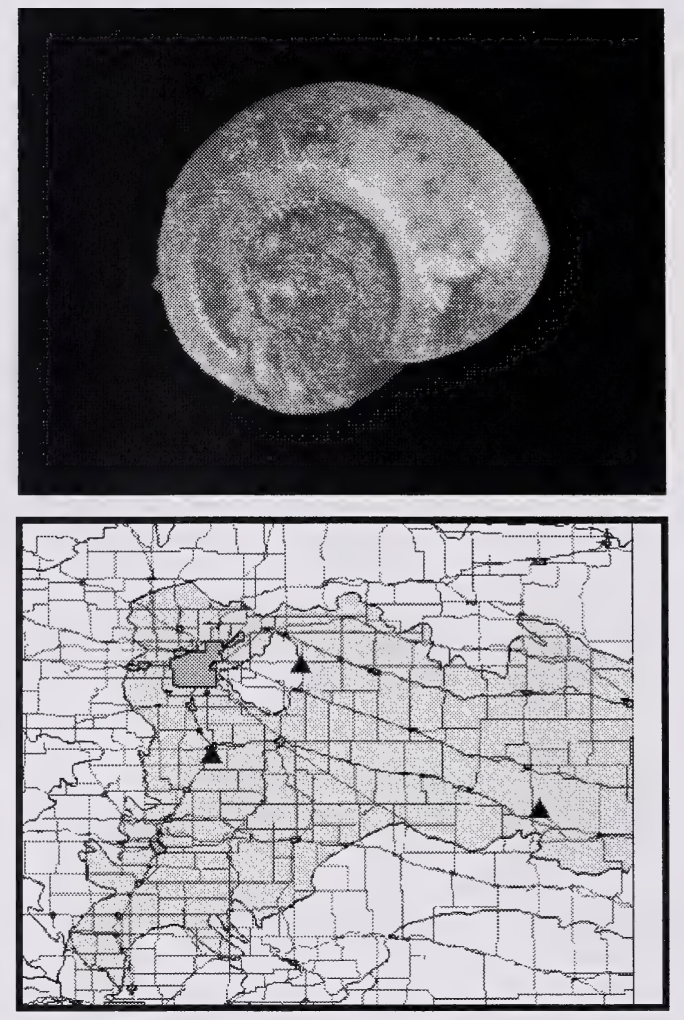

\section{Characteristics}

Present at $3(1.5 \%)$ of 197 sites Alive at $2(1.0 \%)$ of 197 sites

\begin{tabular}{ccc}
\multicolumn{3}{c}{ Wetland Use: } \\
\hline Type & $\begin{array}{c}\% \text { of occupied } \\
\text { sites }\end{array}$ & $\begin{array}{c}\text { Relative to } \\
\text { availability }\end{array}$ \\
\hline River & $0.0 \%$ & $-100.0 \%$ \\
Lake & $0.0 \%$ & $-100.0 \%$ \\
Creek & $100.0 \%$ & $+358.7 \%$ \\
Pond & $0.0 \%$ & $-100.0 \%$ \\
\hline
\end{tabular}

Abundance:

Mean \#/sample: 1.3 (range: 1-2)

Rare: $66.7 \%$

Common: $0.0 \%$

Uncommon: $33.3 \%$ Abundant: $0.0 \%$

\section{Water Chemistry:}

\section{All Sites}

Mean pH: 8.1 (range: 7.4-9.1)

Mean conductivity: $1.48 \mathrm{mS}$ (range: $0.82-1.99$ )

\section{Sites With Live Specimens}

Mean pH: 7.6 (range: 7.4-7.8)

Mean conductivity: $1.22 \mathrm{mS}$ (range: $0.82-1.62$ ) 


\section{Ferrissia fragilis}

Fragile ancylid

\section{Current Status: Undetermined}

Ferrissia fragilis is Alberta's smallest limpet, reaching a maximum length of $5.5 \mathrm{~mm}$ and a height of $1.6 \mathrm{~mm}$ (Clarke 1981). It is distinguished by the small, thin, fragile shell, straight sides and distinctive oval aperture. The species is typically found in still- and stagnant-water habitats such as lakes, ponds and ditches, but it also occurs in slow moving streams (Clarke 1981, Burch 1989).

According to Clarke (1981), F. fragilis has a limited distribution in Canada, occurring in southwestern British Columbia and southern Ontario and Quebec. It is widely distributed in the United States. Clarke (1981) does not report this as a species encountered in Alberta during his 1960s surveys, although his collection techniques failed to record any Ferrissia species (Lepitzki 2001). The species is common in southern British Columbia and is listed as "apparently secure" (Lee 2000). F. fragilis has been previously recorded at one lake in northeastern Alberta, although identification of this specimen requires confirmation (Lepitzki 2001).

In this survey, a single, dead specimen of $F$. fragilis was found at one site. This location was an unnamed wetland approximately $15 \mathrm{~km}$ north of Edmonton where a pH of 8.6 , and a conductivity of $1.45 \mathrm{mS}$ were measured. $F$. fragilis is known for being attached to plants, rocks, debris and dead mussel shells (Emerson and Jacobson 1976). Therefore, it is not easy to observe or collect by generalized sample techniques such as were used in this study. This species likely occurs at more than the single site reported from the Central Parkland Subregion.

Additional studies, using more specialized sampling techniques, will be required to clarify the status of Ferrissia fragilis in this region. However, it is likely that the species is rare and sporadic in occurrence. 


\section{Ferrissia rivularis}

Creeping ancylid

\section{Current Status: Undetermined}

Ferrissia rivularis is a small limpet with a cap-shaped shell, a rounded apex and an oval aperture (Clarke 1981). This species, unlike $F$. parallelus, has an aperture with convex margins. Adult shells are thicker and larger than $F$. fragilis, reaching $7 \mathrm{~mm}$ in length and $3 \mathrm{~mm}$ in height. In addition, $F$. rivularis is typically associated with moving water.

F. rivularis has been reported to range from New Brunswick to Saskatchewan and south in the United States from Maine to North Dakota, and North Carolina to Wyoming (Clarke 1981). In western Canada, Clarke (1981) does not report this as a species encountered during his surveys in the 1960s, although his collection techniques failed to record any Ferrissia species (Lepitzki 2001). F. rivularis is found across southern British Columbia and is listed as "apparently secure" in that province (Lee 2000). A few Ferrissia specimens have been collected in the province, but species identification is required (Lepitzki 2001).

Surveys in the Central Parkland Subregion confirm that this species occurs in central Alberta. $F$. rivularis was collected from $5(2.5 \%)$ sites sampled, all from various locations along the North Saskatchewan and Red Deer rivers. In the areas where it was found, the species was most often observed to be "uncommon" (2-10 individuals), with no more than 4 individuals being found at a sample site. Living specimens were found at a single site, where a pH of 9.3 and a conductivity of $0.30 \mathrm{mS}$ were recorded.

Ferrissia rivularis lives attached to plants, rocks, debris and dead mussel shells (Emerson and Jacobson 1976), and as such, is generally hidden and not easily observed or collected. Therefore, the species likely occurs at more than the five sites reported in this study. The species does appear to be restricted to larger rivers in the province, and would therefore be expected to have a rather localized distribution. More focused sampling is needed to clarify the status of this, and other species of Ferrissia in the province. 


\section{Ferrissia parallelus}

Oblong ancylid

\section{Current Status: Undetermined}

Ferrissia parallelus is a small limpet with a capshaped shell, rounded apex and oval aperture. The species can be differentiated from the other two limpets found in the province by the straight, almost parallel, sides of the aperture and larger size, with adult shells attaining a length of $9 \mathrm{~mm}$ (Clarke 1981). The species lives on stems of cattails and sedges in standing waterbodies, including lakes and swamps, as well as in slow-moving rivers (Clarke 1981).

According to Clarke (1981), F. parallelus has an eastern distribution, ranging from Newfoundland and Prince Edward Island to southern Manitoba and into the northern United States. Studies done in southern Manitoba in the 1970 s reported $F$. parallelus to be a rare species, but further research conducted in 1998 failed to locate this species (Pip 2000). In British Columbia, the species occurs throughout the province and is listed as being "secure" (Lee 2000). In Alberta, Clarke (1973) does not report this as a species encountered during his surveys during the 1960 s, although his collection techniques failed to record any Ferrissia species (Lepitzki 2001). A few Ferrissia specimens have been previously collected in the province but species identification is required (Lepitzki 2001).

In the Central Parkland Subregion, F. parallelus was found at only one site. Three dead individuals were collected from Crestomere Lake, on the western edge of the Subregion, west of Ponoka. At this site, a $\mathrm{pH}$ of 9.1 and a conductivity of $0.57 \mathrm{mS}$ were measured. F. parallelus lives attached to plants, rocks, debris and dead mussel shells (Emerson and Jacobson 1976), and is generally hidden and not easily observed and collected. Our generalized sampling techniques undoubtedly underestimated the occurrence of all limpet species.

It is suspected that Ferrissia parallelus occurs at more than the single location reported in this study. More focused sampling is needed to clarify the status of this, and other, species of Ferrissia in the province.
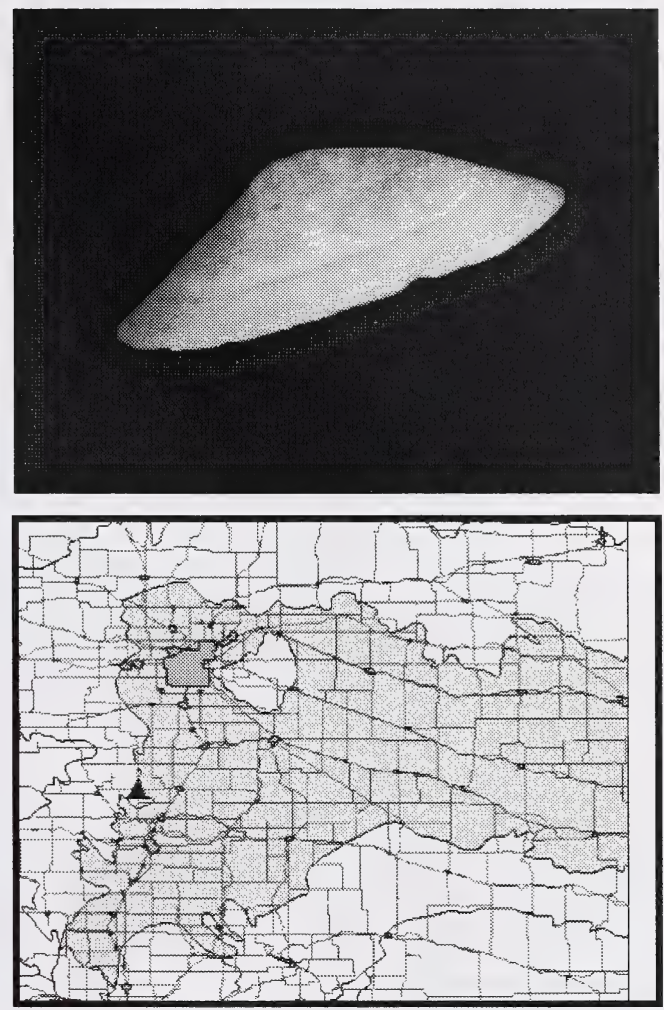

\section{Characteristics}

Present at $1(0.5 \%)$ of 197 sites Alive at $0(0.0 \%)$ of 197 sites

Wetland Use:

\begin{tabular}{ccc}
\hline Type & $\begin{array}{c}\% \text { of occupied } \\
\text { sites }\end{array}$ & $\begin{array}{c}\text { Relative to } \\
\text { availability }\end{array}$ \\
\hline River & $0.0 \%$ & $-100.0 \%$ \\
Lake & $100.0 \%$ & $+194.1 \%$ \\
Creek & $0.0 \%$ & $-100.0 \%$ \\
Pond & $0.0 \%$ & $-100.0 \%$ \\
\hline
\end{tabular}

\section{Abundance:}

Mean \#/sample: 3.0 (range: N/A)

Rare: $0.0 \%$

Common: $0.0 \%$

Uncommon: $100.0 \%$ Abundant: $0.0 \%$

\section{Water Chemistry:}

\section{All Sites}

Mean pH: 9.1 (range: N/A)

Mean conductivity: $0.57 \mathrm{mS}$ (range: N/A)

\section{Sites With Live Specimens}

Mean $\mathrm{pH}$ : N/A

Mean conductivity: N/A 


\begin{tabular}{|c|c|c|c|c|c|c|c|c|c|c|c|c|c|c|c|c|c|c|c|c|c|c|c|c|c|c|c|c|c|c|c|c|c|c|c|}
\hline șuejnn! eIssüә] & & & & & & & & & & & & & & & & & & & & & & & & & & & & & & & & & & & \\
\hline 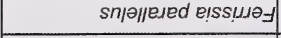 & & & & & & & & & & & & & & & & & & & & & & & & & & & & & & & & & & & \\
\hline 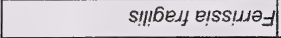 & & & & & & & & & & & & & & & & & & & & & & & & & & & & & & & & & & & \\
\hline sulsadues elnquoueld & & & & & & & & & & & & & & & & & & & & & & & & & & & & & & & & & & & \\
\hline esәбіuाue efnquoued & & & & & & & & & & & & & & & & & & & & & & & & & & & & & & & IN & & & & \\
\hline 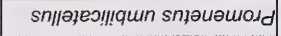 & & & & & & & & & & & & & & - & & & & & & & & & & & & & & & & & & & & & \\
\hline seбәш 'ә snјәиәшолd & & & & & & & & & & & & & & & & & & & & & & & & & & & & & & & & & & & \\
\hline snonvexә 'ә snłəиәuоd & & & & & & & m & & & $\infty$ & & $\nabla$ & & & & \% & & & & & & & क & & & & & & & & & & & ก & \\
\hline s!uejnэәdo snјəuәW & & & & & & & & & & 8 & & & & $\nabla$ & & & & & & & & & & & & & & 의 & & & & & & - & \\
\hline ełeuəגoqns e\|ləquouedd & ก & & 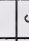 & 0 & & & $\sigma$ & & $\mathrm{N}$ & & & 9 & & & & 위워 & กิ & m & $m$ & 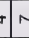 & $\infty$ & $=$ & & 웅 & & n & n & क) & & 우 & & & (5) & & \\
\hline !Кәии!q eाlaquoue/d & & & & & & & & & & & & & & & & & & & & & & & & & & & & & & & & & & & \\
\hline 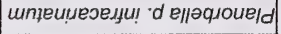 & & & & & & & & & & & & & & & & & & & & & & & & & & & & & & & & & & & \\
\hline ejejnuedues e\|ləquoueld & & & & & & & & & & & & & & & & & & & & & & & & & & & & & & & & & & & \\
\hline sdəoue 'e euos!l|H & & & & & & & & & & $\mathscr{0}$ & & & & & & & & & & & & & & & & & & & & & & & & & \\
\hline snued snineskg & 0 & & & & & & & & r & 章 & $\infty$ & & & (5) & & & $\infty$ & & & & & & $\nabla$ & & & & & & N & & 운 & & m & & \\
\hline 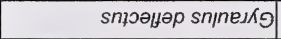 & & & & & & - & in & & $\stackrel{m}{=}$ & क्ल & $\simeq$ & $\infty$ & & & & ६ & & 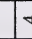 & \% & กิ & & $\bar{i}$ & 2 & $\infty$ & & $\bar{\infty}$ & & ลָ & & & $\stackrel{\infty}{2}$ & & m & $\infty$ & \\
\hline 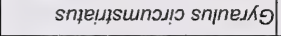 & $\nabla$ & & & & & & m & & $\%$ & $\frac{0}{\sim}$ & $\nabla$ & m & & $\stackrel{\infty}{\sim}$ & & & & & $\approx$ & & N & & $\cong$ & & & $\nabla$ & & . & & i & A & & & & \\
\hline elșio sninesko & m & & & & & & & & & 욤 & & N & & & & - & - & & 6 & & & & क & N & & ले & & m. & & 0 & $\cong$ & & & N & \\
\hline 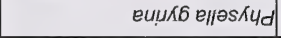 & & $\sim$ & & 5 & & & - & & & $\mathscr{0}$ & & $\nabla$ & & - & & 의 & ㅇ․ & - & & & $\sigma$ & & . & & & & กิ & क्ले & $\overline{7}$ & & & $\sim$ & m & & \\
\hline yəuulys esKud & $\div$ & & 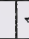 & - & & & $\sim$ & & $\Xi$ & & & - & & क) & & & & 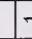 & $-\approx$ & 实 & - & & $r$ & $n$ & & m & & - & & $\infty$ & $\approx$ & & & 요 & \\
\hline 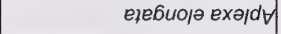 & & & & & & & & - & & & & & & & & & & & & - & & & & & & & & & & & & & & & \\
\hline s!!!xә ejoग!u6ełs & & & & & & & & & & $\div$ & & & & & & & & & & & & & & & & & & & & & & & & & \\
\hline sәродә ерот!ибетs & 9 & & & N & & & & $\overline{5}$ & & $\infty$ & & 足 & & & & & & $\infty$ & $\omega m$ & 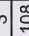 & 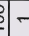 & $\sim$ & - & প্লি & & 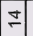 & $\sim$ & & - & $\nabla$ & 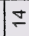 & - & $m$ & - & \\
\hline unidossejes o ejostúbeis & & & & & & & & & & & & & & & & & & & & & & & & & & & & & & & & & & & \\
\hline eұesədes ejostubets & & & & & & & & & & & & & & & & & & & $\sim$ & & & & & & & & & & & & & & & - & \\
\hline essardde s!!eubełs еәеиик7 & in & & & $\infty$ & & & - & & & & $\sim$ & 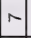 & & & & ละ & $\simeq$ & $=$ & m & & & - & & & & & & 命 & & $\infty$ & & & & & \\
\hline ellas!pou euessoy & & & & & & & & & & & & & & & & & & & & & & & & & & & & & & & & & & & \\
\hline eueqfé e euessoy & & & & & & & & & & 는 & $\infty$ & & & & & & & & & & & & & & & & & & & & & & & & \\
\hline !llep euessoy & & & & & & & & & & & & & & & & & & & $\sigma$ & & & & & & & & & & & & & & & & \\
\hline еұеицетип еұельел & & & & 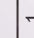 & -0 & & & & & 要 & $\begin{array}{ll}0 \\
0 \\
0 \\
0\end{array}$ & & & & & $\infty$ & & & & & & & & & & - & & $\stackrel{2}{ \pm}$ & & & & & & & \\
\hline едәэи!s 's ерелјел & & & & & & & & & & & & & & & & $\infty$ & & & & & & & & & & & & ष्) & & & & & & & \\
\hline ISIMәI / етелеА & & & & & & & & & & & & & & & & & & & & & & & & & & & & & & & & & & & \\
\hline & \begin{tabular}{|c|}
$\begin{array}{l}n \\
\infty \\
-\infty\end{array}$ \\
\end{tabular} & $\begin{array}{ccc} & 4 \\
\infty & 0 \\
\end{array}$ & $\infty ?$ & 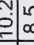 & 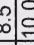 & $\dot{0}$ & $\left(\begin{array}{c}\infty \\
\infty\end{array}\right.$ & $\sigma^{\circ}$ & के & ஸ̃ & \begin{tabular}{l}
$\infty$ \\
\hdashline \\
\end{tabular} & $\begin{array}{l}0 \\
\infty \\
\end{array}$ & $\begin{array}{l}m \\
\infty \\
\infty\end{array}$ & $\bar{\sigma}$ & & $\begin{array}{ll}0 & \\
\infty & \end{array}$ & $\sigma_{0}^{8}$ & \begin{tabular}{c|c} 
& 0 \\
$\infty$ & 0 \\
\end{tabular} & की & {$\left[\begin{array}{l}5 \\
\infty\end{array}\right.$} & $\mid \begin{array}{l}0 \\
\infty \\
\infty\end{array}$ & $\sigma_{\sigma}$ & $\begin{array}{l}0 \\
\infty\end{array}$ & \begin{tabular}{|l|l}
$n$ \\
$\infty$ \\
0
\end{tabular} & $\begin{array}{l}1 \\
\infty\end{array}$ & \begin{tabular}{|l|}
$\infty$ \\
\end{tabular} & $\bar{\sigma}$ & $\bar{\sigma}$ & & $\dot{a}$ & & & N & & $\hat{\sigma}$ \\
\hline 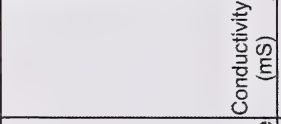 & & & & & & & & & & & ڤొ & $\begin{array}{l} \\
\\
0 \\
0\end{array}$ & $\begin{array}{l}\text { 웅 } \\
\frac{0}{5}\end{array}$ & & & & & & సิ & & & & & $\stackrel{\circ}{\circ}$ & $\begin{array}{l}\hat{A} \\
\bar{\sigma}\end{array}$ & & & & & & & & $\hat{A}$ & & $\begin{array}{l}m \\
0 \\
\dot{\omega} \\
\hat{\omega}\end{array}$ \\
\hline 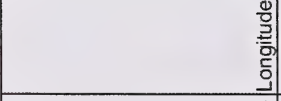 & $\begin{array}{l}0 \\
0 \\
0 \\
0 \\
=\end{array}$ & \begin{tabular}{l}
$\sigma$ \\
$\sigma$ \\
\hdashline \\
$=$
\end{tabular} & 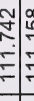 & \begin{tabular}{c|l}
$\infty$ \\
$\leftarrow$ \\
$\leftarrow$ \\
$\leftarrow$
\end{tabular} & 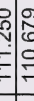 & $=$ & $=\left[\begin{array}{l}\frac{0}{\infty} \\
\infty \\
0 \\
\frac{0}{-}\end{array}\right.$ & 章 & 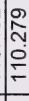 & \begin{tabular}{c}
$\infty$ \\
0 \\
0 \\
0 \\
\hdashline \\
\end{tabular} & $\begin{array}{l}1 \\
0 \\
0 \\
0 \\
0 \\
\end{array}$ & 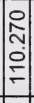 & $\begin{array}{l}\infty \\
0 \\
0 \\
0 \\
\end{array}$ & 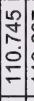 & \begin{tabular}{l}
$\hat{\delta}$ \\
$\vdots$ \\
0 \\
\hdashline
\end{tabular} & 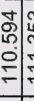 & స్లి & 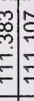 & 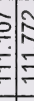 & $=\left[\begin{array}{ll}0 \\
0 \\
0\end{array}\right.$ & 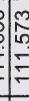 & 递 & $\frac{9}{0}$ & & $\begin{array}{c}\hat{N} \\
f \\
\dot{c} \\
\end{array}$ & 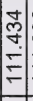 & 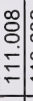 & 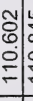 & 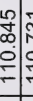 & 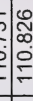 & $\begin{array}{l}5 \\
0 \\
0\end{array}$ & 웅 & \begin{tabular}{|l|}
$m$ \\
\\
\\
\\
\\
\end{tabular} & 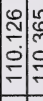 & \begin{tabular}{l}
0 \\
0 \\
0 \\
0 \\
\hdashline \\
\end{tabular} \\
\hline 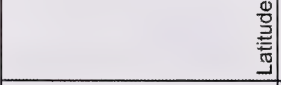 & $\mid$\begin{tabular}{c}
$\infty$ \\
\hdashline \\
$\sim$ \\
$\sim$
\end{tabular} & & & 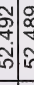 & 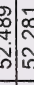 & : & 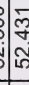 & & 总 & 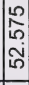 & 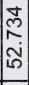 & 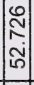 & 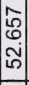 & $\begin{array}{l}5 \\
5 \\
\sim \\
i n\end{array}$ & & 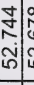 & 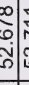 & 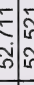 & 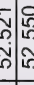 & & & 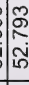 & 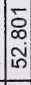 & 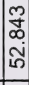 & 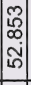 & 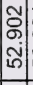 & $\begin{array}{l}\text { Ŝ } \\
0 \\
\text { î }\end{array}$ & $\begin{array}{l}\tilde{N} \\
\text { N̦ } \\
\text { in }\end{array}$ & 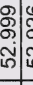 & 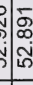 & 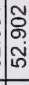 & & 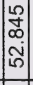 & 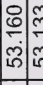 & 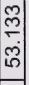 \\
\hline $\begin{array}{l}\frac{\tilde{E}}{0} \\
\frac{\pi}{2} \\
0 \\
\frac{\pi}{0} \\
\frac{\pi}{0}\end{array}$ & 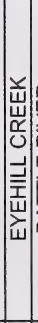 & & 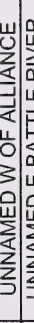 & 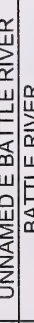 & 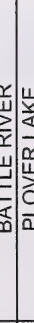 & 岁 & 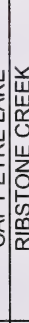 & 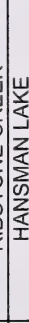 & 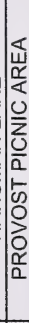 & 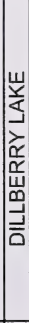 & 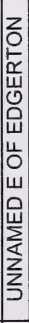 & 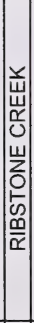 & 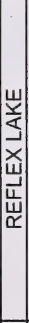 & 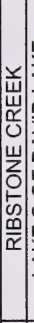 & 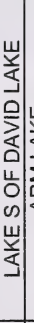 & 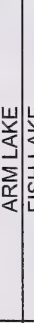 & & 空 & 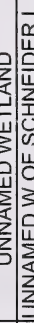 & 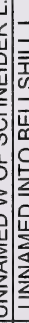 & 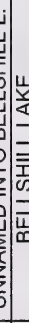 & 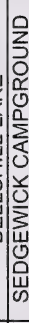 & 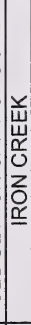 & 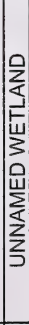 & 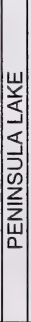 & 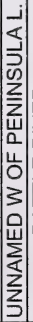 & 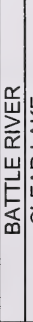 & 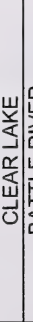 & 㥯 & (1) & & 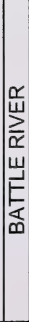 & 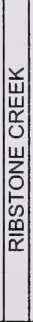 & 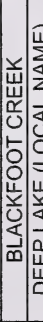 & 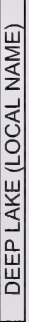 \\
\hline $\begin{array}{l}\frac{0}{0} \\
\frac{\pi}{\overline{0}} \\
\text { Dे } \\
3\end{array}$ & 立 & $\begin{array}{l}\alpha \\
\\
\underline{\alpha} \\
\end{array}$ & 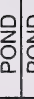 & ऐ) & $\frac{\gamma}{\bar{r}}\left|\frac{u}{\square}\right|$ & 4 & & 崖 & $\begin{array}{l}0 \\
0 \\
0\end{array}$ & $\frac{u}{5}$ & $\frac{щ}{\frac{\pi}{5}}$ & 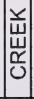 & \begin{tabular}{|l}
$\omega$ \\
\\
\\
\end{tabular} & 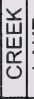 & س & 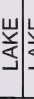 & w & $\frac{⿱}{w}$ & วิ) & 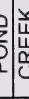 & بإ & 岁 & 親 & 응 & 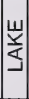 & 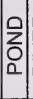 & $\frac{\alpha}{\dot{w}}$ & $\underset{د}{w}$ & $\stackrel{\alpha}{\vec{\alpha}}$ & לֶ. & $\begin{array}{l}0 \\
0 \\
0\end{array}$ & $\frac{\alpha}{\tilde{\mu}}$ & & 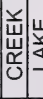 & $\frac{\omega}{\underline{x}}$ \\
\hline$\stackrel{9}{5}$ & 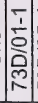 & 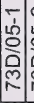 & 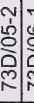 & 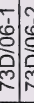 & 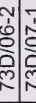 & مी & : & مै & $\begin{array}{l}m \\
0 \\
0 \\
0 \\
0 \\
0\end{array}$ & ํㅗㅇ & 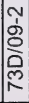 & 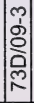 & 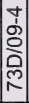 & 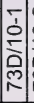 & 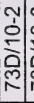 & 䚄: & 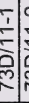 & 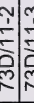 & 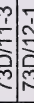 & $\hat{v}$ & مَ & مُ & مै & ले & 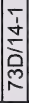 & 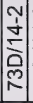 & $\begin{array}{c}m \\
\dot{y} \\
\stackrel{5}{0} \\
\tilde{N}\end{array}$ & 官 & 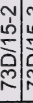 & مْ & 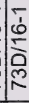 & مَ & 负 & 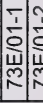 & $\mid \begin{array}{c}N \\
\frac{1}{0} \\
\text { p. } \\
\end{array}$ \\
\hline
\end{tabular}




\begin{tabular}{|c|c|c|c|c|c|c|c|c|c|c|c|c|c|c|c|c|c|c|c|c|c|c|c|c|c|c|c|c|c|c|c|c|c|c|c|c|c|c|}
\hline 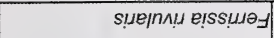 & & & & & & & & & & & & & & & & & & & & & & & & & & & & & & & $\nabla$ & & m & & & & & \\
\hline 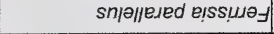 & & & & & & & & & & & & & & & & & & & & & & & & & & & & & & & & & & & & & & \\
\hline s!!!6eג! e!ss!uرə] & & & & & & & & & & & & & & & & & & & & & & & & & & & & & & & & & & & & & & \\
\hline sulsadues elnqfoueld & & & & & & & & & & & & & & & - & & & & - & & & & & & & & & & & & & & & & & & & \\
\hline esəfiulue e/nquoue/d & & & & & & & & & & & & & & & & & & & & & & & & & & & & & & & & & & & & & & \\
\hline 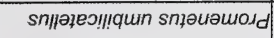 & & & & & & & & & & & & & & & & & & & & & & & & & & & & & & & & & & & & & & \\
\hline seбәи 'ә snјәиәшодd & & & & & & & & & & & & & & & & & & & & & & & & & & & & & & & & & & & & & & \\
\hline snonvexә 'ә snјәиәuоd & & & & & & & & & & & & & & & & 2 & 4 & 4 & & 0 & & & & & $\infty$ & & 5 & ? & & & N & & & & & & & \\
\hline suejnวגәdo snjəuəw & & & & & & & & & & & & & & & & 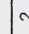 & v & & & & & & & & & & & & & $\sim$ & & & & - & & & & \\
\hline ejeuəjoqns e\|/әquoue/d & - & & $\sqrt{10}$ & & & & & $\sim$ & & 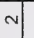 & & & & m. & of & 5 & & & - & N & $\infty$ & & $\begin{array}{l}\infty \\
+ \\
\sigma\end{array}$ & & $\nabla$ & & c & s. & & - & & & & & & & & r \\
\hline !Кәиичq e/ןәqоие/d & & & & & & & & & & & & & & & & & & & & & & & & & & & & & & & & & & & & & & \\
\hline 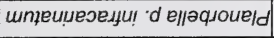 & & & & & & & & & & & & & & & & & & & & & & & & & & & & & & & & & & & & & & \\
\hline ejejnuedues e\|laquoue/d & & & & & & & & & & & & & & & & & & & & & & & & & & & & & & & & & & & & & & \\
\hline sdəoue e emos!|नH & & & & & & & & & & & & & & & & & & & & & & & & & & & & & & & & & & & - & s & & \\
\hline snued snineskg & & & & m & & & & & & & & & & & r & & & : & & ले & $\wedge$ & - & & & 의 & & No & $m$ & $\stackrel{\infty}{\infty}$ & $\infty$ & & & - & + & సี & ○) & $\nabla$ & $\forall$ \\
\hline 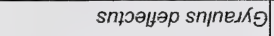 & -1 & r & 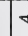 & 0 & tr & & & & & -5 & & & & $\sim$ & - & -7 & $m$ & $\infty$ & $\sqrt[4]{4}$ & & & & & & $\frac{j}{=}$ & & $\circ$ & & $m$ & $=$ & & & & & $=$ & & \pm 0 & \\
\hline 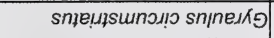 & & 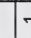 & - & 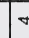 & & & & & & & & & & & & & & 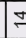 & & & & & ल & & 의 & & & & $\theta$ & & & & & & & & & \\
\hline อ7șuo snjneikg & & & & & & & & $N$ & & & & & & & N. & 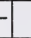 & & $\approx$ & 2 & $\sim$ & & & & & $\stackrel{\infty}{\sim}$ & & & & & - & & & & N & & & . & \\
\hline 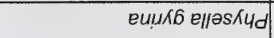 & & & 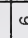 & & & & & & & & & & & $\exists$ & & $\infty$ & & & & ฮ & 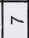 & & $\nabla$ & & & & & & & & & & 2 & & N & m & & ๑) \\
\hline !əuu!ys esKud & - & $r$ & + & 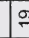 & in & n & & m & & & $\omega$ & & & & 60 & 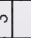 & $\sigma$ & $\dddot{\pi}$ & - & & & & & & \pm & & r & - & 요 & 운 & & & & N & & & & $\infty$ \\
\hline eұeб биора exə/dt & & & & & & & & & & & & & & & & & & & & & & & & & & & & & & - & & & & & & & & \\
\hline s!!!xә ејоэ!u6e1S & & & & & & & & & & & & & & & & & & & & & & & & & & & & v & & & & & & & & & & \\
\hline sәроја ероэ!uбets & - & s & t & 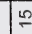 & 20 & - & & $\infty$ & & & 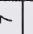 & & & & N) & & & & $\infty$ & & & & & & $\nabla$ & & & & - & 으 & $N$ & & & & & & & \\
\hline un!dossejes :o ejos!u6eis & & & & & & & & & & & & & & & & & & & & & & & & & & & & & & & & & $\div$ & & & & & \\
\hline ejeıаdes eןos!u6ets & & & & & & - & & & & & & & - & & & $\sim$ & & & & $\nabla$ & & & & & & & & & & & & & & & - & & & - \\
\hline 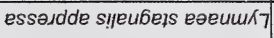 & क) & & 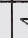 & t & & & & & & & & & & + & $r$ & $\stackrel{\infty}{q}$ & or & & & $\infty$ & N & & & & 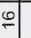 & & - & & $\sim$ & & & & & $\nabla$ & & - & $\begin{array}{lll}\infty & 10\end{array}$ & ( ) \\
\hline Ellas!pou euesso & - & & & & & & & $\infty$ & & & & & & & & & & & & & & & & & & & & & & & & & & & & & & \\
\hline eueqief enessoy & & & & & & & & & & & & & & & & & & & & & & & & & & & & & & & & & & & & & & \\
\hline !IIep euesso_ & & & & & & & & & & & & & - & & & $m$ & & & & & - & & & & & & & & & & & & & & & & & - \\
\hline ејецијет!л еұелјел & & & & & & & & & & & & & & 6 & & הু & & & & $\stackrel{\infty}{\circ}$ & & & 읙 & & & & & & & & $\nabla$ & & & & & & & \\
\hline eләтuIs 's ejenjen & & & & & & & & & & & & & & & & & & & & & & & & & & & & & & & & & & & & & & \\
\hline 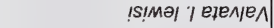 & & & & & & & & & & & & & & & & & & & & & & & & & & & & & & & & & & & & & & \\
\hline & के & $\sigma_{0}$ & 5 & s: & {$\left[\begin{array}{l}10 \\
0\end{array}\right.$} & $\begin{array}{l}\infty \\
\infty \\
\infty\end{array}$ & $\stackrel{\circ}{\circ}$ & \begin{tabular}{|l|} 
\\
$\infty$ \\
\end{tabular} & 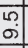 & $\begin{array}{ll}0 & 1 \\
\infty\end{array}$ & & जे & $\bar{\sigma}$ & $\bar{\sigma}$ & $\begin{array}{ll}m & \\
\infty & \end{array}$ & se & की & 5 & 象 & $\mid \begin{array}{c}0 \\
\infty\end{array}$ & $\begin{array}{l} \\
\infty \\
\end{array}$ & 品 & \begin{tabular}{|c|}
6 \\
$\infty$
\end{tabular} & $\begin{array}{c} \\
\infty\end{array}$ & $\circ$ & जे. & & & 5 & $\underbrace{}_{\infty}$ & $\vec{\infty}$ & $\mid$ & o. & & & & $\sigma^{\sigma} \sigma^{\circ}$ & (n) \\
\hline 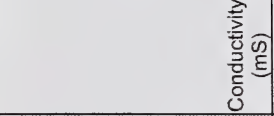 & & & & & & & & & & $\stackrel{\bullet}{-}$ & & & & & & & & & & & & & ठ্ & & & & & & & & : & $\mid$\begin{tabular}{c}
$\infty$ \\
\hdashline \\
-
\end{tabular} & & & & & 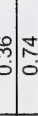 & \begin{tabular}{c}
\multirow{2}{*}{} \\
$\vdots$ \\
$\dot{0}$
\end{tabular} \\
\hline & & $\begin{array}{l}\text { की } \\
6 \\
6\end{array}$ & $\begin{array}{l}n \\
\vdots \\
\vdots \\
\vdots \\
\vdots \\
\vdots \\
\vdots\end{array}$ & 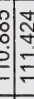 & 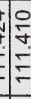 & $\stackrel{\infty}{\substack{N \\
\hdashline}}$ & 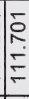 & $\begin{array}{l}0 \\
\emptyset \\
\emptyset \\
\mp \\
\end{array}$ & 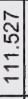 & \begin{tabular}{l}
0 \\
0 \\
0 \\
\hdashline \\
\hdashline \\
\hdashline
\end{tabular} & $\begin{array}{l}0 \\
0 \\
\tilde{E} \\
= \\
=\end{array}$ & 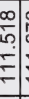 & 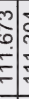 & : & $\begin{array}{l}0 \\
\bar{z} \\
\bar{c}\end{array}$ & 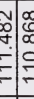 & \begin{tabular}{l|l}
0 \\
0 \\
0 \\
0 \\
\hdashline \\
\hdashline
\end{tabular} & {$\left[\begin{array}{l}\infty \\
0 \\
0 \\
0 \\
0\end{array}\right.$} & $\mid \begin{array}{l}0 \\
0 \\
0 \\
0 \\
0\end{array}$ & 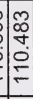 & \begin{tabular}{c} 
Na \\
0 \\
0 \\
\hdashline
\end{tabular} & 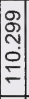 & \begin{tabular}{c}
0 \\
어 \\
0 \\
0 \\
\hdashline \\
\end{tabular} & $\underset{\hdashline}{\simeq}$ & \begin{tabular}{l}
$\infty$ \\
0 \\
0 \\
0 \\
\hdashline \\
\hdashline
\end{tabular} & 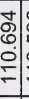 & :ִ: & 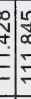 & \begin{tabular}{l}
$\qquad$ \\
\hdashline \\
\hdashline
\end{tabular} & {$\left[\begin{array}{l}8 \\
0 \\
\infty \\
\end{array}\right.$} & \begin{tabular}{l}
$\mid 8$ \\
0 \\
0 \\
\hdashline \\
\end{tabular} & \begin{tabular}{l}
$\mathbb{N}$ \\
$\mathbf{6}$ \\
\hdashline \\
\hdashline \\
$=$
\end{tabular} & \begin{tabular}{l|l} 
\\
$\overline{0}$ \\
$\circ$ \\
$\circ$ \\
$=$
\end{tabular} & 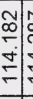 & 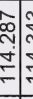 & & & $\begin{array}{l}\bar{\sigma} \\
\overline{5} \\
\\
\end{array}$ \\
\hline 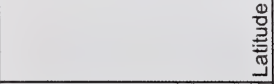 & $\begin{array}{l}0 \\
\tilde{0} \\
0 \\
\infty\end{array}$ & & 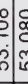 & & 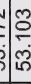 & 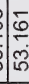 & 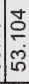 & 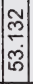 & 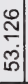 & 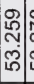 & 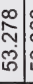 & 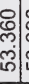 & & 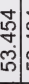 & \begin{tabular}{c|c}
5 \\
0 \\
0 \\
0 \\
0
\end{tabular} & & 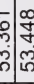 & & $\left\{\begin{array}{l}\infty \\
\frac{\infty}{t} \\
i^{\prime}\end{array}\right.$ & 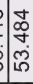 & مु & 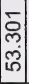 & $\begin{array}{l}0 \\
0 \\
0 \\
0 \\
0\end{array}$ & 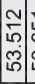 & 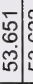 & 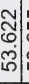 & مُ & & & 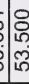 & $\begin{array}{l}0 \\
0 \\
0 \\
0 \\
0 \\
10\end{array}$ & $\begin{array}{l}n \\
\infty \\
\infty \\
0 \\
0\end{array}$ & 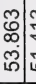 & $\begin{array}{l}m \\
\vdots \\
\dot{y}\end{array}$ & 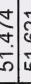 & & & 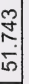 \\
\hline $\begin{array}{l}\tilde{g} \\
\frac{0}{n} \\
\frac{0}{0} \\
\frac{\pi}{0}\end{array}$ & 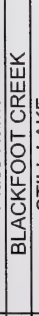 & 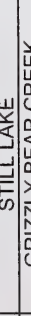 & 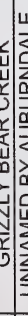 & 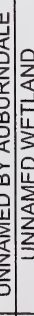 & & 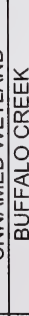 & & 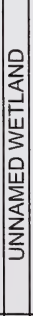 & 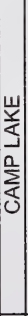 & 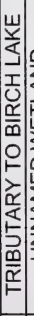 & 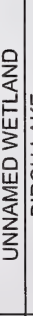 & 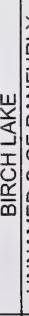 & 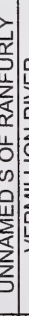 & 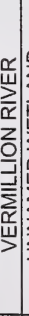 & 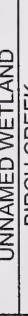 & 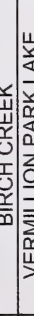 & 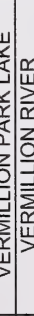 & | & 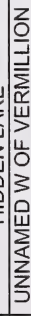 & 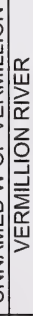 & 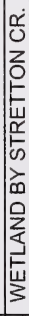 & 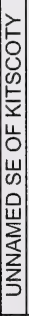 & 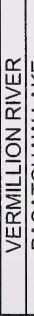 & 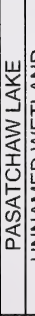 & 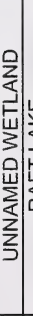 & 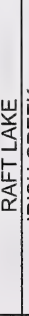 & 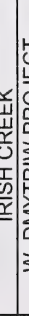 & ע. & 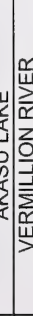 & $=$ & 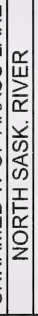 & 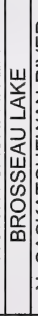 & 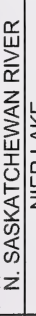 & $\frac{\omega}{\underline{c}}$ & 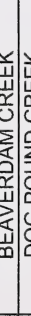 & 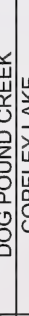 & 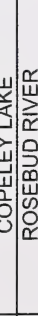 & 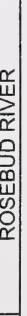 \\
\hline 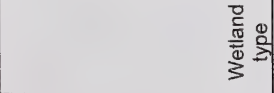 & $\mid \begin{array}{c}\frac{y}{u} \\
\underline{x} \\
0\end{array}$ & 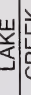 & & $\begin{array}{c}\frac{1}{2} \\
\frac{1}{3} \\
\end{array}$ & 2 & 崫 & $\frac{w}{5}$ & $\begin{array}{l}0 \\
0 \\
0 \\
0\end{array}$ & 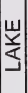 & 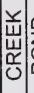 & 号 & 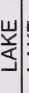 & 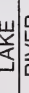 & $\sum_{\bar{\alpha}}^{\frac{\alpha}{u}}$ & ○) & 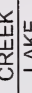 & $\frac{\vec{y}}{5} \mid \frac{\alpha}{\Delta}$ & & $\left\{\begin{array}{l}0 \\
0 \\
0\end{array}\right.$ & $\sum_{\bar{x}}$ & o & & 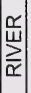 & \begin{tabular}{|l}
$\mathbf{w}$ \\
$\mathbf{s}$ \\
\end{tabular} & 号. & 岁 & $\frac{1}{4}$ & : & $\frac{\alpha}{\alpha}$ & $=$ & 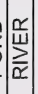 & \begin{tabular}{|l} 
\\
\\
\end{tabular} & $\underset{\sim}{\stackrel{\alpha}{\omega}}$ & 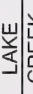 & 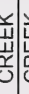 & & $\underset{\Sigma}{\stackrel{u}{\mid 山}}$ & $\frac{\alpha}{\stackrel{\alpha}{\alpha}}$ \\
\hline 亲 & 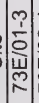 & 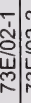 & 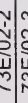 & 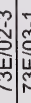 & 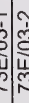 & $\hat{~}$ & 竞 & 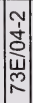 & 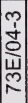 & 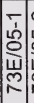 & 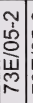 & 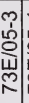 & ○े & 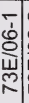 & 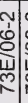 & 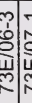 & 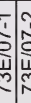 & 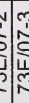 & : & 离 & $\begin{array}{l}\sim \\
\infty \\
0 \\
\tilde{w} \\
\tilde{n}\end{array}$ & \begin{tabular}{|c|} 
\\
0 \\
$\infty$ \\
0 \\
\\
\\
\end{tabular} & 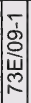 & 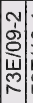 & 它 & సे & 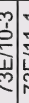 & $\frac{7}{c}$ & 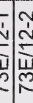 & $=\sqrt[n]{\frac{3}{4}}$ & 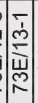 & 永 & 它 & 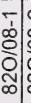 & 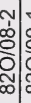 & 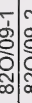 & 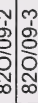 & 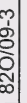 \\
\hline
\end{tabular}




\begin{tabular}{|c|c|c|c|c|c|c|c|c|c|c|c|c|c|c|c|c|c|c|c|c|c|c|c|c|c|c|c|c|c|c|c|c|c|c|c|c|c|c|}
\hline șuejnn!u eissüy] & & & & & & & & & & & & & & & m & & & & & & & & & N & & & & & & & & & & & & & & \\
\hline sniəlejed eissüz] & & & & & & & & & & & & & & & & & & & & & & & & & & & & & & & & & & & & & & \\
\hline s!!!beд е!ssuнә & & & & & & & & & & & & & & & & & & & & & & & & & & & & & & & & & & & & & & \\
\hline s!njsadures ejnquoue/d & & - & & & & & & & & & & & & & & & & & & & & & & & & & & & & & & & & & & & & \\
\hline esabiluse ejnquoueld & & & & & & & & & & & & & & & & & & & & & & & & & & & & & & & & & & & & & & \\
\hline 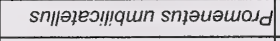 & & & & & & & & & & & & & & & & & & & & & & & & & & & & & & & & & & & & & & \\
\hline se6әи 'ә snјәиәиолd & & & & & & & & & & & & & - & & & & & & & & ని & & & & & & & & & & & & & & & & & \\
\hline 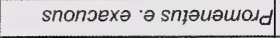 & & & & - & & - & & & & & & & क) & & & & $\nabla$ & & & m & $\mathscr{D}_{\infty}$ & & & & & ง & m & & & & & N & & & & 17 & & \\
\hline s!uepnoגədo sməuәW & & & - & & & & & & N & & & & & & & & & & & & $\underset{\sim}{\infty}$ & & & & & & - & & & & & & & & & & & $\infty$ \\
\hline еұеuәرoqns ellaquoue/d & - & N & $\varphi$ & & - & 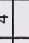 & & N & & & - & 12 & $m=$ & $\bar{F}$ & & No & N & & & & $\sim$ & & N & & & - & ง & & & N & & 5 & $2-$ & & $\nabla$ & & & \\
\hline !Kəuи!q elləquoueld & & & & & & & & & & & & & & & & & & & & & & & & & & & & & & & & & & & & & & \\
\hline 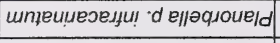 & & & & & & & & & & & & & & & & & & & & & & & & & & & & & & & & & & & & & & \\
\hline ejejnuedues e\|lequoueld & & & & & & & & & & & & & & & & & & & & & & & & & & & & & & & & & & & & & & \\
\hline sdəoue e ewos!laH & & & & & & & & & & & & & & & & & & & & & & & & & & & & & & & & & & & & & & \\
\hline snued snineגiog & & & น) & m) & & (1) & & & & & - & & 2 & & & & : & 의 & & g & $\int_{\substack{0 \\
7}}^{7}$ & N & & & & ल) & क) & 안 & : & & क) & $\infty$ & & & & $\nabla$ & - & $\infty$ \\
\hline 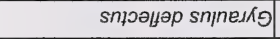 & & ले & & क & $m$ & $c$ & . & 4 & & & N & $\hat{m}$ & का & r & & & \pm & $i$ & e. & 0 & $\sqrt{2}$ & - & $\sqrt{n}$ & & & & & n. & $\infty$ & & ลิโ & $\frac{7}{3}$ & 20 & - & 0 & & & L \\
\hline smie!lsunoul snineikg & & & & 0 & & & in & & & - & & & $=$ & & N. & -5 & 의 & & & 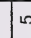 & $\cong$ & & & & & & is & & & & م & & & & & m & & $\sim$ \\
\hline 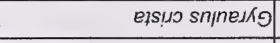 & & 8 & & & & & - & & & & & - & - & & & & $\mp$ & nc & - & 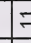 & $=\frac{\infty}{2}$ & & & & & ง & $\sim$ & & 아 & & & - & & & $r$ & & & \\
\hline 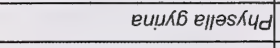 & & & & స & of. & - & & A & & $\exists$ & $\stackrel{\infty}{\circ}$ & - & $\nabla$ & & $\bar{\sigma}$ & & & & I & $=$ & $\div$ & & & क & $\sim$ & & & - & & $\mathcal{7}$ & 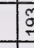 & 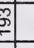 & & & & & ก & 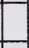 \\
\hline Ləuulys esKyd & & $\infty$ & (5) & & & & o & m & & & & 4 & $\sim$ & & & का & 65 & $F$ & 子 & $\cong$ & $\sqrt{\pi}$ & $\simeq$ & - & & & N & ㄱㅇㅛ & $\sim$ & i & & & $F$ & $=m$ & $2 m$ & $\infty$ & 6 & & $\sigma$ \\
\hline eұeбио ә ехәлty & & & & & & & & & & & & & & & & & & & & & & & & & & & & & $\checkmark$ & & & & & & $\cong$ & & & \\
\hline s!!!xə e/oग!u6eis & & & & & & & & & & & & & & & & & & & & & & & & & & & & & & & & & & & & & & \\
\hline sәродә ероэтибеis & & $\nabla$ & N & & & & & in & & & & $m$ & $\sim:$ & & & ofo & $\infty$. & $-c$ & $m$ & $\sqrt{12}$ & 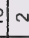 & & 8 & & & & mi & ฮิ & 이 & & c & $m$ & & & $\infty$ & & - & \\
\hline un!dossejes 's ejostubets & & & & & & & & & & & & & & & & & & & & & & & & & & & & & & & & & & & & & & \\
\hline ejesades ejosubeis & & & & & & & & & & & & & & & & & & & & & & & & & & & & & & & & & & - & $\pi$ & & & \\
\hline essardde s!̣eufe]s eәеuик 7 & & 요 & $\simeq$ & & & & & N & & & & n & & & & & & & & & & & - & & & & in 6 & $m$ & 앙 & $\sim$ & & $\because$ & & & & is & & \\
\hline Eוləo!pou euesso- & & & & & & & & & & & & & & & & & & & & & & & & & & & & & & & & & & & & & & \\
\hline eueqje6 enesso- & & & & $\exists$ & & & & & & & & & & & $\infty$ & & & & & & & & & is & & & & & & & & $\exists$ & & & & & & \\
\hline !|lep euesso_ & & & & & & & & & & & & - & & & & & & & & m & $\theta$ & & & & & & & & & - & 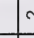 & N & & & & & & \\
\hline еұеицетил еұелел & & & & & & & & & & & & & & & Б) & & & & & & 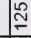 & & & & & & & & & & & - & & & & 요 & & i \\
\hline eגәэuls 's efenjen & & & & & & & & & & & & & & & & & & & & $\infty$ & & & & & & & & & & & & m & & & & & & \\
\hline 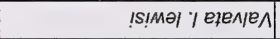 & & & & & & & & & & & & & & & & & & & & & & & & & & & & & & & & & & & & & & \\
\hline I & के & \begin{tabular}{l|l}
0 & \\
$\infty$ & \\
\end{tabular} & कें० & के & sid & $0 \begin{array}{c}0 \\
\infty \\
\infty\end{array}$ & $\begin{array}{l}\infty \\
0 \\
\infty\end{array}$ & $\infty$ & $\mid \begin{array}{c}n \\
\infty \\
\infty\end{array}$ & $\bar{\sigma}$ & के & के & No & $\bar{\infty}-5$ & m.t? & ज़) & $\begin{array}{l}7 \\
\infty\end{array}$ & $\int_{0}^{5}$ & 5 & 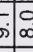 & क. & के & $\begin{array}{c}7 \\
\infty\end{array}$ & $\bar{\infty}$ & $\begin{array}{l}\text { के } \\
\infty\end{array}$ & \begin{tabular}{|l|} 
\\
$\infty$
\end{tabular} & \begin{tabular}{|l|l}
0 & 0 \\
0 & 1 \\
\end{tabular} & क्र & & & & 0 & : & क. & & $\begin{array}{c}1 \\
\infty\end{array}$ & & 웅 \\
\hline 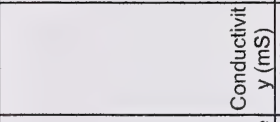 & & & & & & & & & & & & & & & & & & & & & $\mid \begin{array}{l}8 \\
\infty \\
0\end{array}$ & & & $\begin{array}{l}0 \\
0 \\
0 \\
0\end{array}$ & & & & & & & & & & & & $\begin{array}{l}0 \\
\vdots \\
\vdots \\
\bullet\end{array}$ & & $\begin{array}{l}0 \\
\infty \\
0 \\
0\end{array}$ \\
\hline 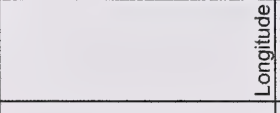 & 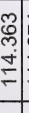 & 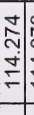 & 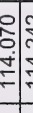 & 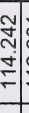 & 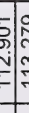 & 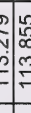 & 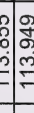 & : & 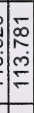 & \begin{tabular}{|l} 
\\
0 \\
\\
\\
\end{tabular} & $\begin{array}{l}\hat{n} \\
\dot{0} \\
m \\
\\
\end{array}$ & $\begin{array}{l}\stackrel{0}{0} \\
\stackrel{2}{m} \\
\stackrel{m}{-}\end{array}$ & 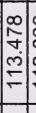 & 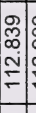 & 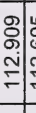 & 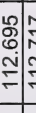 & 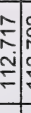 & 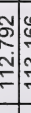 & $=\frac{\infty}{\square}$ & 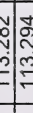 & 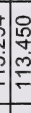 & 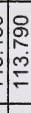 & 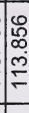 & 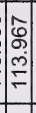 & 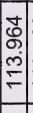 & 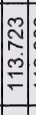 & 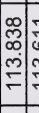 & $\begin{array}{c}- \\
\bar{\sigma} \\
m \\
\bar{\sigma} \\
\end{array}$ & 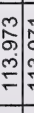 & 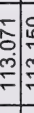 & 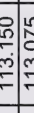 & 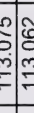 & 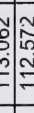 & 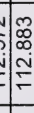 & 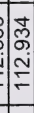 & $\begin{array}{l}\bar{\tau} \\
\bar{N} \\
\\
\bar{\tau}\end{array}$ & $\begin{array}{l}\bar{N} \\
\underset{N}{N} \\
\overline{=}\end{array}$ & $\stackrel{ }{\stackrel{0}{ }}$ \\
\hline 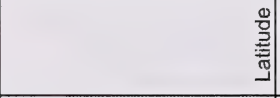 & & & ले & Бे & & & ‘) & 究 & 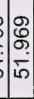 & $\begin{array}{l}\infty \\
\infty \\
\infty \\
\check{\infty} \\
\end{array}$ & $\begin{array}{c}0 \\
\infty \\
\infty \\
\vdots \\
\text { in } \\
\end{array}$ & $\begin{array}{l}\underset{\sim}{\infty} \\
\vdots \\
\text { in } \\
\end{array}$ & ר్ & 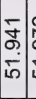 & 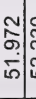 & 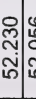 & เి & 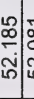 & : & 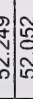 & 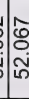 & {$\left[\begin{array}{c}\infty \\
\frac{\infty}{n}\end{array}\right.$} & 放 & 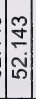 & $\begin{array}{l}\text { م્ } \\
\text { ले } \\
\text { กิ }\end{array}$ & 文 & 代 & 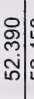 & 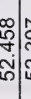 & & & & 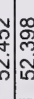 & 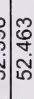 & in & 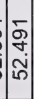 & 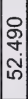 & 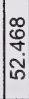 \\
\hline $\begin{array}{l}\xi \\
\bar{n} \\
2 \\
0 \\
\frac{\pi}{0} \\
\frac{\pi}{\alpha}\end{array}$ & 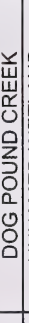 & 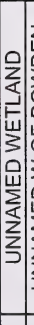 & & 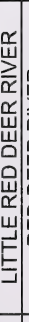 & & & ב- & 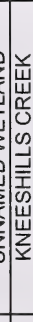 & 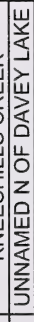 & 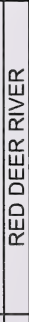 & 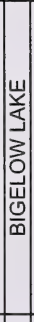 & 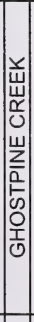 & 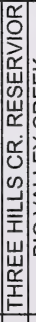 & 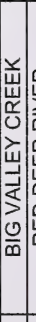 & 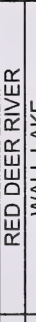 & 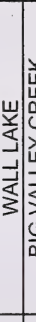 & 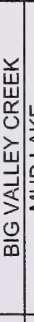 & 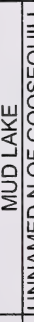 & 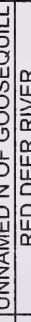 & 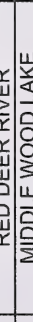 & 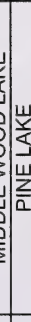 & 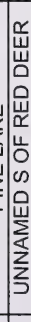 & 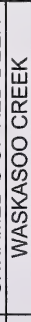 & 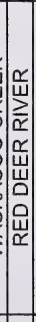 & 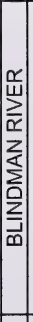 & 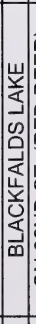 & 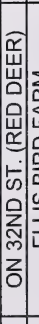 & 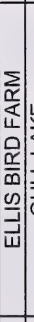 & & 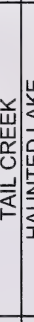 & 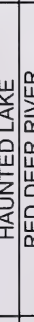 & 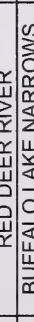 & 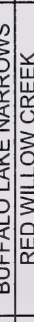 & 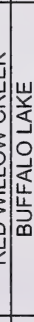 & 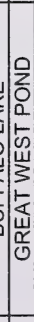 & 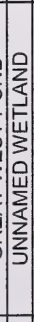 & 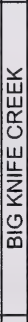 & 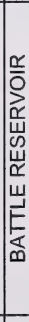 \\
\hline 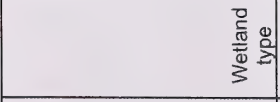 & 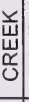 & & & & & & & $\frac{x}{\mathrm{w}}$ & 5 & $\frac{\widetilde{\alpha}}{\stackrel{\sim}{\alpha}}$ & $\begin{array}{l}\frac{w}{5} \\
\frac{w}{5}\end{array}$ & 离 & $\begin{array}{l}\omega \\
\frac{2}{5} \\
\end{array}$ & \begin{tabular}{|c|} 
\\
$\vec{u}$ \\
$\widetilde{c}$ \\
\\
\end{tabular} & 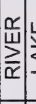 & 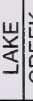 & 离 & & 攰题 & $\frac{x}{y} \mid \begin{array}{l}\frac{x}{2} \\
\frac{1}{y}\end{array}$ & $\frac{u}{5}$ & 送 & 立 & 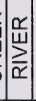 & $\underset{\sim}{\stackrel{\alpha}{\Psi}}$ & 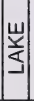 & 임 & 吕 & & 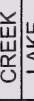 & 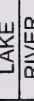 & 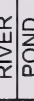 & ว & பً & $=\begin{array}{l}0 \\
0 \\
0\end{array}$ & $\begin{array}{l}0 \\
2 \\
0 \\
0\end{array}$ & 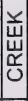 & $\frac{u}{\square}$ \\
\hline$\stackrel{\frac{g}{5}}{5}$ & 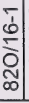 & & & $\begin{array}{c}\frac{1}{b} \\
\frac{0}{0} \\
\infty \\
\infty\end{array}$ & 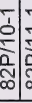 & 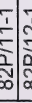 & 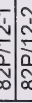 & 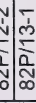 & 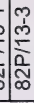 & $\begin{array}{l}- \\
\\
\\
\\
\infty \\
\infty\end{array}$ & 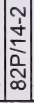 & 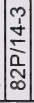 & 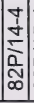 & & 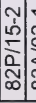 & & 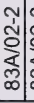 & & 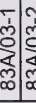 & 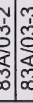 & 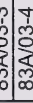 & 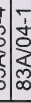 & $\sum_{\infty}^{N}$ & 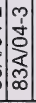 & 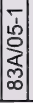 & 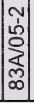 & 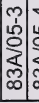 & 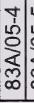 & & ఏ్లి & 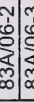 & 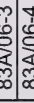 & 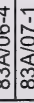 & 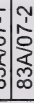 & :ִ & $\mid \begin{array}{l}\bar{c} \\
\infty \\
\vdots \\
\vdots \\
\vdots \\
\infty \\
\infty \\
0\end{array}$ & 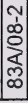 & 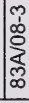 \\
\hline
\end{tabular}




\begin{tabular}{|c|c|c|c|c|c|c|c|c|c|c|c|c|c|c|c|c|c|c|c|c|c|c|c|c|c|c|c|c|c|c|c|c|c|c|c|c|c|c|}
\hline s!̣e|nı! e!sșuә & & & & & & & & & & & & & & & & & & & & & & & & & & & & & & & & & & & & & & \\
\hline snjəl|ejed e!ssula & & & & & & & & & m & & & & & & & & & & & & & & & & & & & & & & & & & & & & & \\
\hline s!!!6eд e!ssüн] & & & & & & & & & & & & & & & & & & & & & & & & & & & & & & & & & & & & & & \\
\hline sulsədures emquoued & & & & & & & & & & & & & & & & & & & & & & & 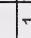 & & & & & & & & & & & & & & & \\
\hline esəбiluse epnquoueld & & & & & & & & & & & & & & & & & & & & & & & & & & & & & & & & & & & & & & \\
\hline sn||әzеJ!!qun snjauәuodd & & & & & & & & & & & & & & & & $N$ & & & & & & & & & & & & & & & & & & & & & & \\
\hline 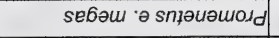 & & & & & & & & & & & & & & & & & & & & & & & & & & & & & & & m & & & & & & & \\
\hline snonวexә 'ә sməuәuодd & & & & & & & m & & ल्ल & & & & & - & & & & & & & & - & & & $\sim$ & $\nabla$ & & & & & $\infty$ & & & & m) & & & $\sim$ \\
\hline sцерпدадо snұəuәW & & & & & & & & & & & & & & & & & & & & & - & & & & $\sim$ & & & & & & & & & & & & & \\
\hline eұeuəjoqns e\|əquoue/d & & & & & & & & ง & & ) & ง & & & & $\stackrel{\infty}{-}$ & 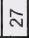 & $\infty$ & & - & & $F=$ & $\neq$ & m & & & & $\div$ & $=$ & N & N & $\infty$ & m & & & N & ๙ & is & \\
\hline 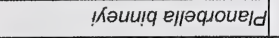 & & & & & & & & & & & & & & & & & & & & & & & - & & & & $\nabla$ & & & & & & & & & & & \\
\hline 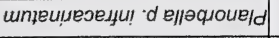 & & & - & & & & & & & & & & & $m$ & & & & & $\infty$ & & & & & & & & & & & & & & & & & & & \\
\hline ejejnuedues e\|ləquoue/d & & & & & & & & & & & & & & & & & & & & & & & & & & & & & & & & & & & & & & \\
\hline sdəoue 'e euros!|rH & & & & & & & & & & & & & & & & & & & & & & & & & m & & 우 & & & & & & & & & & & \\
\hline snNed snineskg & & & & & & & & & 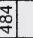 & & & & & i & & & & $=$ & & & $\stackrel{\infty}{\sim}$ & & $\bar{\gamma}$ & & $+\infty$ & 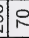 & & & & & 6 & & & & 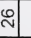 & & & $\bullet$ \\
\hline 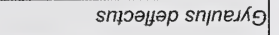 & & - & & & & & $\nabla$ & & $8=$ & $F-$ & $-\sigma$ & \% & $\sqrt{-}$ & & 12 & & t & 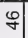 & & & กิด & N & $\div$ & & - & $\frac{1}{2}$ & $N$ & & - & 요 & क & $\infty$ & & & & & & $\infty$ \\
\hline 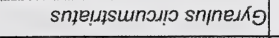 & & & & & & & & - & 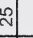 & & & & & & & & 者 & $m$ & & - & & & & & & $\stackrel{\infty}{\infty}$ & & - & & & (a) & & & & & & & \\
\hline 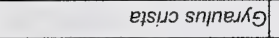 & & & & & & & & $-r$ & No & s & & & - & - & & - & च & & & & m & & & & & $\omega$ & & & m & $\bar{N}$ & - & & & & - & & & \\
\hline 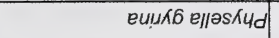 & $\infty$ & & m & & & & $-1=$ & $=$ & & & ก & $v$ & & N & $m$ & & & & क & $\sim i$ & 吕 & & & s & 28 & & $\simeq$ & & & & | & & & & 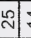 & $\forall$ & & $\infty$ \\
\hline بәuulys eskyd & & & $\sim$ & & & & & m & $m \div$ & 의운 & $=0$ & & 우 & & & $\infty$ & ก & & क & & & เ & 6 & & & $\infty$ & & & $\stackrel{2}{2}$ & is & 2 & 0 & & & $\infty$ & & & \\
\hline еұебиолә еxә/dy & & & & & & & & & & & & & & & & & & & & & & & & & & $\sigma$ & & & & & | & & & & & & & \\
\hline s!!!xə e/oग!u6ejs & & & & & & & & & & & & & & & & & & & & & & - & & & & & & & & & . & & & & & & & \\
\hline sәродә елоэйеis & - & & & & & & -10 & N & $\nabla \div$ & $\circ-$ & * & & & & N & \pm & $\infty$ & & & & & เ & m & c & $m=$ & $y>$ & $\sqrt{2}$ & $\infty$ & $\infty$ & & क) & & & m & & & m & \\
\hline un!dossejes o epos!ubets & & & & & & & & & & & & & & & & & & & & & & & & & & & & & & & & & & & & & & \\
\hline ęеләdел елотибетs & & & & & & & & & & & & & & & & & & & & & & 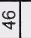 & & & n & & & & & & & & & & & & & \\
\hline essajdde s!jeubejs eәeuuк7 & & & & & & & & - & -2 & m & & & & & 6 & & 0 & & $\lambda$ & & & N & & & & $\nabla$ & i & & & & N & क) & & & & & & \\
\hline eाןo⿰pоu euesso- & & & & & & & & & & & & & & & & & & & & & & & & & & & & & & & & & & & & & & \\
\hline eиeqpé euessot & & & & & & & & & & & & & & & & & & & & & & & & & & & & & & & & & & & & & & \\
\hline !IIEp euessoy & & & & & & & & -1 & N- & - & & & & & & & & & & & & - & & & 政 & & $\theta$ & & & & & & & & & & & \\
\hline еұеинетин еұелјел & & & & & & & m: & N & & & & & & $\mathscr{8}$ & & & & & & $\exists$ & & & & - & - & & $\ddot{\infty}$ & & & & & & & & 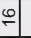 & & & : \\
\hline EגәJUIS 's ejen/en & & & & & & & & $-i$ & र & & & & & $\stackrel{\infty}{\infty}$ & & & & & & & & & & & & & & & & & & & & & & & & \\
\hline Is!Mә । ејел/ел & & & & & & & & & & & & & & & & & & & & & & & & & & & & & & & & & & & & & & - \\
\hline I & $n$ & $\widehat{\sigma}$ & $\begin{array}{c}\nabla \\
\infty\end{array}$ & \begin{tabular}{|l|}
$\infty$ \\
$\sigma$ \\
$\sigma$
\end{tabular} & ㅇ. & \begin{tabular}{c|c|} 
& \\
$\infty$ &
\end{tabular} & 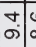 & \begin{tabular}{l|l}
0 \\
$\infty$
\end{tabular} & $\bar{\sigma}$ & $\infty$ & 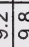 & & in & $\bar{\infty}_{\infty}$ & $\bar{\sigma}$ & $\frac{\pi}{\pi}$ & $\bar{\sigma}$ & \begin{tabular}{|l|} 
\\
0 \\
0 \\
0
\end{tabular} & $\begin{array}{l}\text { के } \\
\text { | }\end{array}$ & $\begin{array}{l}0 \\
\sigma\end{array} \mid$ & बें & $\begin{array}{l}0 \\
\infty \\
\infty\end{array}$ & 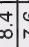 & & : & $\begin{array}{c}\text { y̦ } \\
\end{array}$ & i & 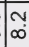 & m. & ஸै & $\begin{array}{l}m \\
\sigma\end{array}$ & $\begin{array}{c}m \\
\sigma\end{array}$ & & $D_{\infty}^{+}$ & & & $\left.\hat{N}\right|_{\infty} ^{\infty}$ & $\begin{array}{l}0 \\
\infty \\
\infty\end{array}$ \\
\hline 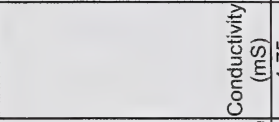 & & & & & & & & & & & & & 2 & & & $\stackrel{\sigma}{\longrightarrow}$ & & & & {$\left[\begin{array}{c}1 \\
1 \\
0 \\
0\end{array}\right]$} & & & & & & & & & & 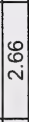 & 官 & & & & & & & क़े \\
\hline 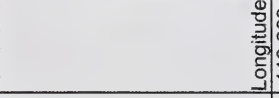 & 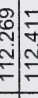 & 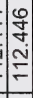 & 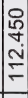 & 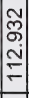 & 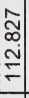 & 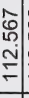 & 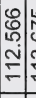 & 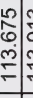 & 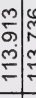 & 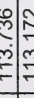 & 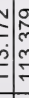 & & $=\left[\begin{array}{l}\infty \\
0 \\
0 \\
\frac{m}{=}\end{array}\right.$ & $\left\{\begin{array}{l}\infty \\
\infty \\
\infty \\
m \\
\end{array}\right.$ & 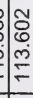 & $\begin{array}{l}0 \\
\stackrel{0}{m} \\
\stackrel{m}{=}\end{array}$ & 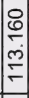 & \begin{tabular}{|l|} 
\\
0 \\
0 \\
$m$ \\
\\
\\
\end{tabular} & $\begin{array}{c}\hat{n} \\
N \\
\\
\\
\end{array}$ & 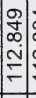 & 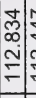 & 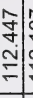 & 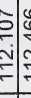 & ה. & : & $\mid$\begin{tabular}{l|l}
5 \\
$\vdots$ \\
$\vdots$
\end{tabular} & 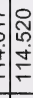 & 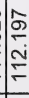 & $\stackrel{n}{\frac{n}{2}}$ & 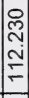 & 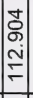 & $\begin{array}{l}\hat{D} \\
\infty \\
\\
\mp \\
\end{array}$ & \begin{tabular}{c} 
\\
$\infty$ \\
$\infty$ \\
\\
\hdashline \\
\end{tabular} & 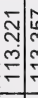 & 勇 & 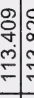 & & 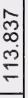 \\
\hline 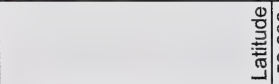 & 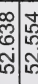 & 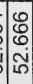 & $\begin{array}{l}\mathscr{8} \\
0 \\
\text { Ni }\end{array}$ & 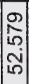 & 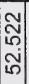 & 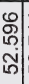 & 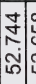 & 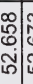 & 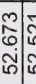 & & & & 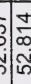 & 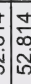 & 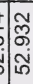 & $\begin{array}{l}\delta \\
\text { o } \\
\text { Ni }\end{array}$ & $\begin{array}{c}\mathbb{N} \\
\infty \\
\mathbb{N} \\
\mathbb{N}\end{array}$ & 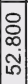 & $\begin{array}{c}N \\
\infty \\
N \\
\end{array}$ & $\begin{array}{l}\infty \\
\tilde{\sigma} \\
\tilde{N}\end{array}$ & $\left.\begin{array}{c}\infty \\
0 \\
\tilde{D} \\
\vdots\end{array}\right]$ & 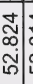 & 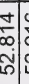 & 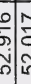 & ș & 5 & 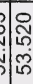 & m & 怘 & $\begin{array}{c}\mathscr{W} \\
\text { N్} \\
\tilde{N}\end{array}$ & $\begin{array}{c}\bar{N} \\
\bar{\sim} \\
\end{array}$ & \begin{tabular}{|c|}
$\infty$ \\
$\sim$ \\
$\sim$ \\
$\tilde{n}$
\end{tabular} & 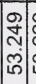 & 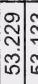 & लె & & & 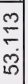 \\
\hline $\begin{array}{c}\frac{y}{\pi} \\
2 \\
\frac{\pi}{0} \\
\frac{\pi}{0}\end{array}$ & 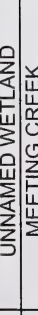 & 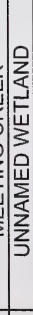 & 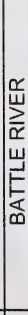 & 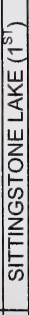 & 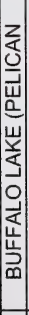 & 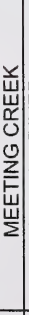 & 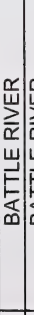 & 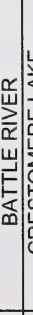 & 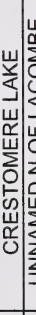 & 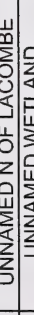 & 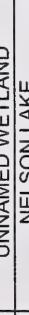 & ב & 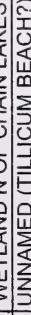 & & 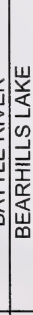 & 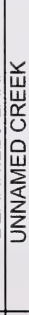 & 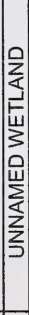 & 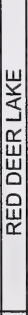 & 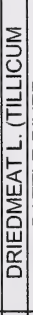 & 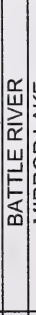 & 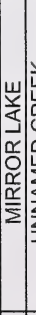 & 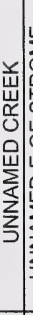 & 崩 & : & 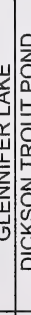 & 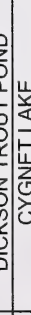 & | & 焉 & 䚄 & 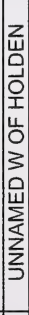 & 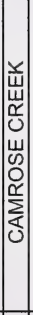 & 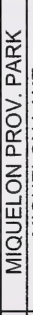 & 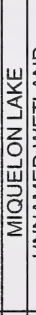 & 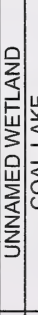 & 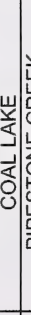 & 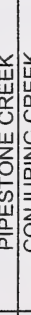 & 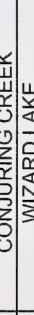 & \\
\hline $\begin{array}{l}\frac{0}{0} \\
\frac{\pi}{0} \\
\frac{0}{3} \\
3\end{array}$ & 司竞 & & $\sum_{\bar{x}}^{\frac{\alpha}{4}}$ & & & & 䍃 & $\stackrel{\frac{\alpha}{w}}{\stackrel{\alpha}{\alpha}}$ & $\frac{w}{5}$ & 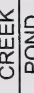 & & & 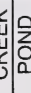 & 䍃 & $=\frac{w}{\Delta}$ & $\frac{⿱}{\mathrm{u}}$ & 임 & \begin{tabular}{|l|} 
\\
\\
\\
\\
\end{tabular} & \begin{tabular}{|l}
$\omega$ \\
$\frac{w}{5}$ \\
\end{tabular} & 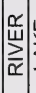 & 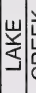 & 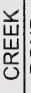 & ऐ) & & 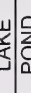 & $\frac{1}{4}$ & كَ & 䇋 & $\begin{array}{l}0 \\
0 \\
0\end{array}$ & O & 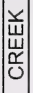 & $\begin{array}{l}0 \\
0 \\
0 \\
0 \\
0\end{array}$ & $\mid \frac{w}{\vec{s}}$ & 过 & 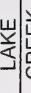 & 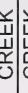 & & $\begin{array}{l}\ddot{\omega} \\
\frac{\Delta}{\leq}\end{array}$ \\
\hline$\frac{9}{5}$ & 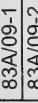 & వర & ఫั & & 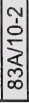 & $\begin{array}{c}m \\
\vdots \\
\vdots \\
\vdots \\
\vdots \\
\infty \\
\infty\end{array}$ & 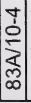 & 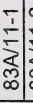 & 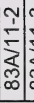 & 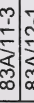 & 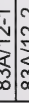 & 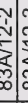 & 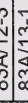 & 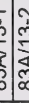 & مे & $\frac{\dot{J}}{\sum_{\infty}^{\prime}}$ & 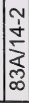 & 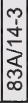 & 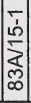 & 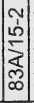 & $\left|\begin{array}{c}0 \\
1 \\
1 \\
\vdots \\
\infty \\
\infty \\
\infty\end{array}\right|$ & 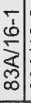 & 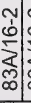 & 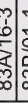 & 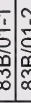 & 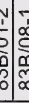 & 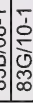 & $\begin{array}{l}\frac{1}{3} \\
\frac{1}{1} \\
\frac{1}{2} \\
\infty\end{array}$ & $\begin{array}{l}\frac{N}{2} \\
\frac{1}{\infty} \\
\frac{1}{2} \\
\infty \\
\infty\end{array}$ & $\begin{array}{l}0 \\
\frac{1}{0} \\
1 \\
\\
\infty \\
\infty\end{array}$ & 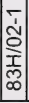 & 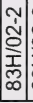 & 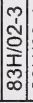 & 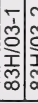 & 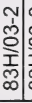 & 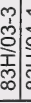 & 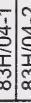 & 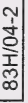 \\
\hline
\end{tabular}




\begin{tabular}{|c|c|c|c|c|c|c|c|c|c|c|c|c|c|c|c|c|c|c|c|c|c|c|c|c|c|c|c|c|c|c|c|c|c|c|}
\hline 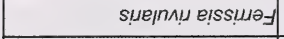 & & & & & & & & & & & & & & & & & & & - & & & & & & & & & & & & & & & \\
\hline sniəl|ejed eissulat| & & & & & & & & & & & & & & & & & & & & & & & & & & & & & & & & & & \\
\hline s!! & & & & & & & & & & & & & & & & & & & & & & & & & & & & & 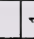 & - & & & & \\
\hline sulsadures elnquoueld & & & & & & & & & & & & & & $\nabla$ & & & & & & & & & & & & & & & & & & & & \\
\hline ejabiuse e/nquoue/d & & & & & & & & & & & & & & & & & & & & & & & & & & & & & & & & & & \\
\hline 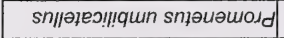 & & & & & & & & & & & & & & & & & & - & & & & & & & & & & & & & & & & \\
\hline se6am 'a snjauamosd & & & & & & & & & & & & & & & & & & ๓ & & & & & & & & & & & & & & & & \\
\hline snonjexə 'a snłəuauidd & & & 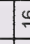 & $\div$ & & & - & r & 4 & & & & & $\infty$ & & & & - & m & & & & 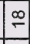 & $\stackrel{\infty}{\sim}$ & $m$ & & & & 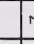 & $\lambda$ & $\mathrm{N}$ & & & \\
\hline sue|nэədo smiəuәW & & & - & - & & & & & & & $\infty$ & & & & & & & & & & & & & $\nabla$ & & & & & & - & & & & \\
\hline 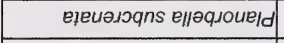 & & & o & ㅇ & & & 요 & : & m & & & & & 0 & & & 안 & & స్ & & 12 & & & N & $\cong$ & & N & & m. & 6 & m & & + & \\
\hline !रәиu!q el/aquoue/d & & & & & & & & & & & & & & & & & & & & & & & & & & & & & & & & & & \\
\hline 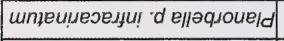 & & & & & & & & & & & & & & & & & & & & & & & & & & & & & & & & & & \\
\hline ejejnuedwes elləquoueld & & 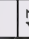 & 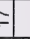 & & & & & & & & & & & & & & & & & & & & & & & & & & & & & & & \\
\hline 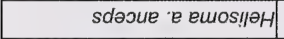 & & & & & & & & & & & & & & & & & & & & & & & & & & & & & & & & & & \\
\hline snued snineskg & & & in & $\bar{\Sigma}$ & & & & & & & & & & & & & & | & N & & 0 & & 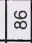 & $\stackrel{2}{2}$ & ? & & - & & & a) & & $\delta^{2}$ & a & \\
\hline 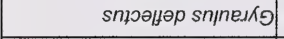 & N & . & $\infty$ & ᄂ & & $4 c$ & m: & in 1 & & & - & & ৪্ল & & & $\infty$ & & है & - & & $\frac{1}{4}$ & & N & 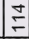 & $\infty$ & $\stackrel{\infty}{-}$ & & - & 5 & $\div$ & & & & g \\
\hline 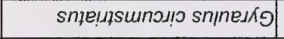 & & & 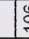 & 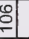 & & & & & $\sigma$ & & & & & & & & & & & & & & & & $N$ & 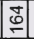 & & & & r & - & & v & \\
\hline eIșu snineגরo & & 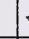 & - & q & & & & & & & & & $m$ & 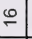 & & - & & & & & & & & $\theta$ & $\sim$ & & & & & m & - & 5 & 。 & \\
\hline 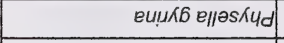 & ง & & & & & & $i$ & 요 & $\infty$ & & m & & & & & & - & & s & - & $\infty$ & & 우 & & & \begin{tabular}{|l|l|} 
\\
$b$ \\
\end{tabular} & $\infty$ & $\cong$ & & & & म & & \\
\hline بәuulys esKud & & r & $\Rightarrow 2$ & m. & - & $A 0$ & n. & & & & & - & $\infty$ & A & & & - & 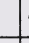 & 0 & & & & & : & 웅 & & & & & $\mp$ & & & 0 & 0 \\
\hline eұeбиоро exə/dy & - & & & & & & & & & & & & & N & & & & $\checkmark$ & & & - & & & & $\sim$ & & . & & & & & & & \\
\hline s!!!xa ejos!ubeis & & & & & & & 2 & m & & & & & & & & & & & & & & & & & & & - & & & & & & & \\
\hline sәрорә ерот!ибетs & & & & 5 & & की & m & & & & & & in & $\infty$ & & & & 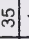 & $\checkmark$ & & & o & & 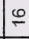 & กิ & กิ & & & & 의 & & : & & $m$ \\
\hline unidossejeo o ejostubeis & & & & & & & & & & & & & & & & & & & & & & & & & & & & & & & & & & \\
\hline ejesadeo ejosiufeis & & & & & & & & & & & & & & & & & & & & & & & & & - & N & & & & & & & & \\
\hline esseıdde s!̣eubełs eәeuuर 7 & - & 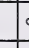 & $\infty 1$ & 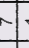 & & & 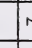 & 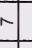 & $\stackrel{2}{2}$ & & 0 & & & & & & $\nabla$ & - & - & 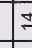 & 更 & & $\infty$ & 0 & - & $\nabla$ & & - & - & - & - & & & $\stackrel{\infty}{-}$ \\
\hline 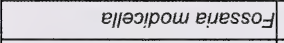 & & & & & & & & & & & & & & & & & & & & & & & & & & & & & & & & & & \\
\hline eueqןe6 enesso- & & & & & & & & & & & & & & & & & & & r & - & & & & & & & & & & & & & & \\
\hline !llep euesso & & & & & & & & & & & & & & & & & & ก & & & - & & & & & $\nabla$ & & & & & & & & \\
\hline еұеииетия еұельел & & & & & & & & & $\div$ & & & & & & & & & & & & ㄱ. & & $\stackrel{\infty}{\tilde{N}}$ & I & & ำ & & & & & & & & \\
\hline 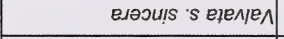 & & f & 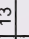 & & & & & & & & & & & & & & & & & & m & & 2 & N & - & & & & & & & & & \\
\hline Is!Mal I EIEN/E & m & 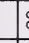 & จ & & & & & & & & & & & & & & & & & & - & & & D & & & & & & & & & & \\
\hline I & $\hat{N}$ & 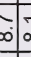 & $\sigma_{0}$ & o: & $\begin{array}{ll}-1 \\
0\end{array}$ & $\hat{n}$ & 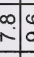 & 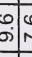 & 0 & $\begin{array}{c}\infty \\
\infty \\
\infty\end{array}$ & $\mid \begin{array}{l}\infty \\
\infty \\
\infty\end{array}$ & 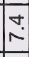 & $\sigma_{\infty}$ & 公 & $\begin{array}{l} \\
\\
\end{array}$ & $\begin{array}{l}\infty \\
\\
\end{array}$ & $\begin{array}{l}\text { Na } \\
\text { ○ } \\
\end{array}$ & 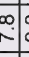 & ". & \begin{tabular}{l|l}
0 & 0 \\
$\infty$ & $\sigma$ \\
\end{tabular} & $\square_{\infty}$ & 10 & $\begin{array}{l}\sigma \\
\infty\end{array}$ & $\begin{array}{l}10 \\
\infty \\
\infty\end{array}$ & ? & की & $\begin{array}{l}0 \\
0 \\
\end{array}$ & \begin{tabular}{|c|c|}
$m$ & \\
$\infty$ &
\end{tabular} & $\begin{array}{ccc}N_{\infty} & 0 \\
\end{array}$ & & \begin{tabular}{l|l|l} 
& \multicolumn{1}{c}{} \\
& & \\
\end{tabular} & \begin{tabular}{c|c|c} 
& \\
$\infty$ & $\infty$ & $\infty$ \\
$\infty$
\end{tabular} & 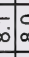 & $\begin{array}{l}0 \\
\infty \\
\infty\end{array}$ \\
\hline 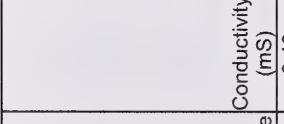 & & & & & & . & & & & & $\int_{0}^{8}$ & & م & $\begin{array}{l}0 \\
\vdots \\
0 \\
0\end{array}$ & 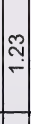 & & & & & & & & & $\hat{0}$ & $\left|\begin{array}{l}\infty \\
0 \\
0\end{array}\right|$ & & $\left|\begin{array}{c}1 \\
0 \\
0\end{array}\right|$ & $\bar{\emptyset}$ & & & & & $\frac{\infty}{m} \mid \geqslant$ & $\stackrel{N}{\sim}$ \\
\hline 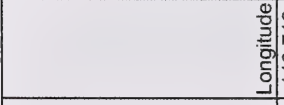 & & $\begin{array}{c}c \\
c \\
c \\
c\end{array}$ & 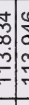 & 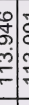 & & 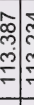 & 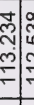 & 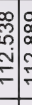 & & 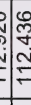 & 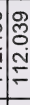 & 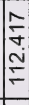 & 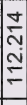 & 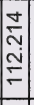 & \begin{tabular}{|l}
$\qquad 0$ \\
0 \\
\\
\hdashline \\
\end{tabular} & 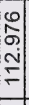 & $\begin{array}{l}\mathscr{2} \\
\sigma \\
\sim \\
\sim \\
\leftarrow\end{array}$ & 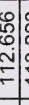 & 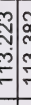 & & $=$ & 竞 & 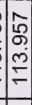 & $\begin{array}{l}\hat{m} \\
\stackrel{n}{m} \\
\stackrel{m}{=}\end{array}$ & 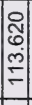 & $\begin{array}{l}\infty \\
0 \\
0 \\
m \\
\\
\end{array}$ & $\begin{array}{l} \\
0 \\
0 \\
\mathrm{~m} \\
\stackrel{2}{=} \\
\end{array}$ & 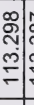 & 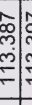 & 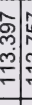 & & 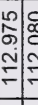 & c: & \\
\hline $\begin{array}{l}0 \\
0 \\
0 \\
0 \\
0\end{array}$ & & & & & & 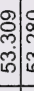 & & & & 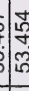 & 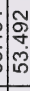 & $\begin{array}{l}\mathscr{D} \\
\text { N } \\
\text { [ె }\end{array}$ & 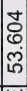 & $\begin{array}{l}\bar{N} \\
0 \\
\tilde{n}\end{array}$ & $\begin{array}{l}0 \\
0 \\
0 \\
0 \\
0\end{array}$ & 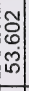 & $\begin{array}{l}0 \\
0 \\
0 \\
\tilde{n}\end{array}$ & & & & & : & & $\begin{array}{l}\text { L } \\
\text { in } \\
\text { in }\end{array}$ & 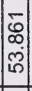 & 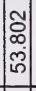 & \begin{tabular}{|c}
$\infty$ \\
$\infty$ \\
$\tilde{乃}$ \\
$\tilde{n}$
\end{tabular} & $\begin{array}{l}9 \\
0 \\
0 \\
\text { గि }\end{array}$ & 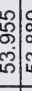 & & 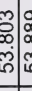 & 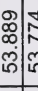 & 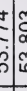 & \\
\hline $\begin{array}{c}0 \\
\frac{0}{\pi 0} \\
2 \\
8 \\
\frac{\Phi}{0}\end{array}$ & & 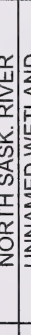 & 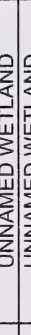 & & & 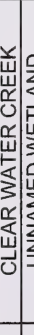 & 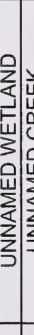 & 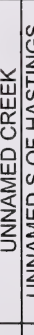 & 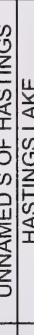 & 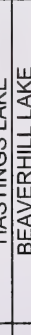 & > & 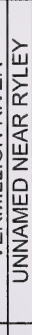 & 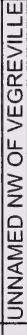 & 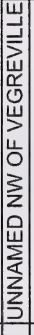 & 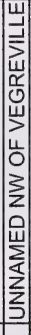 & 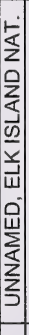 & 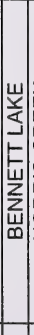 & 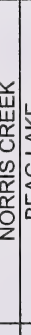 & 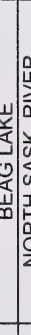 & 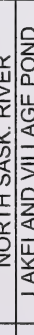 & 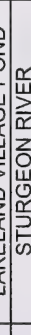 & $=$ & 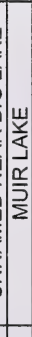 & \begin{tabular}{|l}
$\frac{\omega}{x}$ \\
$\frac{\omega}{\Delta}$ \\
$\frac{0}{\omega}$ \\
\end{tabular} & 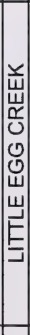 & 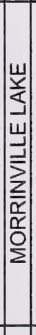 & 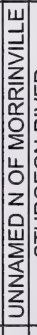 & 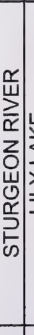 & 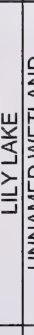 & 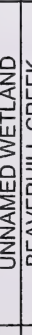 & 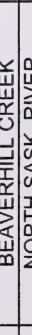 & 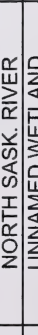 & & 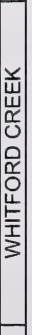 \\
\hline $\begin{array}{l}\bar{E} \\
\overline{0} \\
\overline{0} \\
3\end{array}$ & & & : & 感 & & 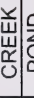 & ऐ) & 学 & & tu & $\frac{\alpha}{x}$ & 足 & O & $\begin{array}{l}0 \\
0 \\
0 \\
0 \\
0\end{array}$ & $\begin{array}{l}0 \\
0 \\
0 \\
0\end{array}$ & 这 & & 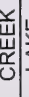 & & 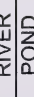 & & $=$ & $\mid \frac{w}{\Delta}$ & $\frac{\omega}{\square}$ & 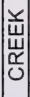 & \begin{tabular}{|l|l} 
\\
\\
\end{tabular} & 이 & $\frac{\alpha}{\Psi}$ & $\underset{s}{w}$ & & & 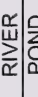 & & 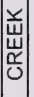 \\
\hline$\stackrel{0}{\bar{\omega}}$ & 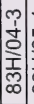 & 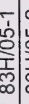 & 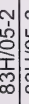 & & & 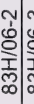 & 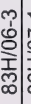 & 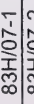 & & 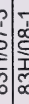 & $=\left[\begin{array}{l}\frac{1}{\infty} \\
\infty \\
\frac{1}{M} \\
\infty\end{array}\right.$ & 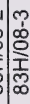 & 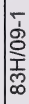 & 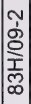 & 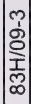 & 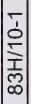 & & $\begin{array}{c}\frac{1}{0} \\
0 \\
\frac{1}{T} \\
\text { m. } \\
\infty\end{array}$ & & & & 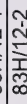 & 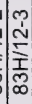 & $\frac{d}{N}$ & 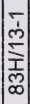 & 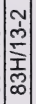 & 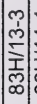 & 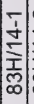 & $\frac{N}{2}$ & & 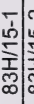 & 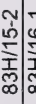 & & 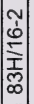 \\
\hline
\end{tabular}




\section{List of Titles in This Series}

(as of June 2004)

No. 1 Alberta species at risk program and projects 2000-2001, by Alberta Sustainable Resource Development, Fish and Wildlife Division. (2001)

No. 2 Survey of the peregrine falcon (Falco peregrinus anatum) in Alberta, by R. Corrigan. (2001)

No. 3 Distribution and relative abundance of the shortjaw cisco (Coregonus zenithicus) in Alberta, by M. Steinhilber and L. Rhude. (2001)

No. 4 Survey of the bats of central and northwestern Alberta, by M.J. Vonhof and D. Hobson. (2001)

No. 52000 survey of the trumpeter swan (Cygnus buccinator) in Alberta, by M.L. James and A. James. (2001)

No. 6 2000/2001 Brassy minnow inventory at Musreau Lake and outlet, by T. Ripley. (2001)

No. 7 Colonial nesting waterbird survey in the Northwest Boreal Region - 2000, by M. Hanneman and M. Heckbert. (2001)

No. 8 Burrowing owl trend block survey and monitoring - Brooks and Hanna areas, by D. Scobie and R. Russell. (2000)

No. 9 Survey of the lake sturgeon (Acipenser fulvescens) fishery on the South Saskatchewan River, Alberta (JuneSeptember, 2000), by L.A. Winkel. (2000)

No. 10 An evaluation of grizzly bear-human conflict in the Northwest Boreal Region of Alberta (1991-2000) and potential mitigation, by T. Augustyn. (2001)

No. 11 Harlequin duck monitoring in the Northern East Slopes of Alberta: 1998-2000 preliminary results, by J. Kneteman and A. Hubbs. (2000)

No. 12 Distribution of selected small mammals in Alberta, by L. Engley and M. Norton. (2001)

No. 13 Northern leopard frog reintroduction. Raven River - Year 2 (2000), by K. Kendell. (2001)

No. 14 Cumulative effects of watershed disturbances on fish communities in the Kakwa and Simonette watersheds. The Northern Watershed Project. Study 3 Progress report, by T. Thera and A. Wildeman. (2001)

No. 15 Harlequin duck research in Kananaskis Country in 2000, by C.M. Smith. (2001)

No. 16 Proposed monitoring plan for harlequin ducks in the Bow Region of Alberta, by C.M. Smith. (2001)

No. 17 Distribution and relative abundance of small mammals of the western plains of Alberta as determined from great horned owl pellets, by D. Schowalter. (2001)

No. 18 Western blue flag (Iris missouriensis) in Alberta: a census of naturally occurring populations for 2000, by R. Ernst. (2000)

No. 19 Assessing chick survival of sage grouse in Canada, by C.L. Aldridge. (2000)

No. 20 Harlequin duck surveys of the Oldman River Basin in 2000, by D. Paton. (2000)

No. 21 Proposed protocols for inventories of rare plants of the Grassland Natural Region, by C. Wallis. (2001)

No. 22 Utilization of airphoto interpretation to locate prairie rattlesnake (Crotalus viridis viridis) hibernacula in the South Saskatchewan River valley, by J. Nicholson and S. Rose. (2001)

No. 23 2000/2001 Progress report on caribou research in west central Alberta, by T. Szkorupa. (2001) 
No. 24 Census of swift fox (Vulpes velox) in Canada and northern Montana: 2000-2001, by A. Moehrenschlager and C. Moehrenschlager. (2001)

No. 25 Population estimate and habitat associations of the long-billed curlew in Alberta, by E.J. Saunders. (2001)

No. 26 Aerial reconnaissance for piping plover habitat in east-central Alberta, May 2001, by D.R.C. Prescott. (2001)

No. 27 The 2001 international piping plover census in Alberta, by D.R.C. Prescott. (2001)

No. 28 Prairie rattlesnake (Crotalus viridis viridis) monitoring in Alberta - preliminary investigations (2000), by S.L. Rose. (2001)

No. 29 A survey of short-horned lizard (Phrynosoma hernandesi hernandesi) populations in Alberta, by J. James. (2001)

No. 30 Red-sided garter snake (Thamnophis sirtalis parietalis) education and relocation project - final report, by L. Takats. (2002)

No. 31 Alberta furbearer harvest data analysis, by K.G. Poole and G. Mowat. (2001)

No. 32 Measuring wolverine distribution and abundance in Alberta, by G. Mowat. (2001)

No. 33 Woodland caribou (Rangifer tarandus caribou) habitat classification in northeastern Alberta using remote sensing, by G.A. Sanchez-Azofeifa and R. Bechtel. (2001)

No. 34 Peregrine falcon surveys and monitoring in the Parkland Region of Alberta, 2001, by R. Corrigan. (2002)

No. 35 Protocol for monitoring long-toed salamander (Ambystoma macrodactylum) populations in Alberta, by T. Pretzlaw, M. Huynh, L. Takats and L. Wilkinson. (2002)

No. 36 Long-toed salamander (Ambystoma macrodactylum) monitoring study in Alberta: summary report 1998-2001, by M. Huynh, L. Takats and L. Wilkinson. (2002)

No. 37 Mountain plover habitat and population surveys in Alberta, 2001, by C. Wershler and C. Wallis. (2002)

No. 38 A census and recommendations for management for western blue flag (Iris missouriensis) in Alberta, by R. Ernst. (2002)

No. 39 Columbian mountain amphibian surveys, 2001, by D. Paton. (2002)

No. 40 Management and recovery strategies for the Lethbridge population of the prairie rattlesnake, by R. Ernst. (2002)

No. 41 Western (Aechmophorus occidentalis) and eared (Podiceps nigricollis) grebes of central Alberta: inventory, survey techniques and management concerns, by S. Hanus, H. Wollis and L. Wilkinson. (2002)

No. 42 Northern leopard frog reintroduction - year 3 (2001), by K. Kendell. (2002)

No. 43 Survey protocol for the northern leopard frog, by K. Kendell. (2002)

No. 44 Alberta inventory for the northern leopard frog (2000-2001), by K. Kendell. (2002)

No. 45 Fish species at risk in the Milk and St. Mary drainages, by RL\&L Environmental Services Ltd. (2002)

No. 46 Survey of the loggerhead shrike in the southern aspen parkland region, 2000-2001, by H. Kiliaan and D.R.C. Prescott. (2002)

No. 47 Survey of native grassland butterflies in the Peace parkland region of northwestern Alberta - 2001, by M. Hervieux. (2002)

No. 48 Caribou range recovery in Alberta: 2001/02 pilot year, by T. Szkorupa. (2002) 
No. 49 Peace parkland native grassland stewardship program 2001/02, by A. Baker. (2002)

No. 50 Carnivores and corridors in the Crowsnest Pass, by C. Chetkiewicz. (2002)

No. 512001 Burrowing owl trend block survey and monitoring, Brooks and Hanna areas, by D. Scobie. (2002)

No. 52 An evaluation of the ferruginous hawk population in Alberta based on recent trend data, by D.P. Stepnisky, G.L. Erickson, J. Iwaasa and B. Taylor. (2002)

No. 53 Alberta amphibian call surveys. A pilot year. Final report, by L. Takats and C. Priestley. (2002)

No. 54 Utilization of a roadside survey technique to survey burrowing owl (Athene cunicularia hypugaea) in southeastern Alberta, by J. Nicholson and C. Skiftun. (2002)

No. 55 Alberta species at risk program and projects 2001-2002, by Alberta Sustainable Resource Development, Fish and Wildlife Division. (2002)

No. 56 Developing a habitat-based population viability model for greater sage-grouse in southeastern Alberta, by C.L. Aldridge. (2001)

No. 57 Peregrine falcon surveys and monitoring in the Northeast Boreal Region of Alberta, 2001, by R. Corrigan. (2002)

No. 582002 burrowing owl trend block survey and monitoring, Brooks area, by R.F. Russell. (2002)

No. 59 Rare plant inventory of the eastern edge of the lower foothills natural subregion, west-central Alberta, by J. Doubt. (2002)

No. 60 Western (Aechmophorus occidentalis) and eared (Podiceps nigricollis) grebes of central Alberta: 2002 field summary, by S. Hanus, L. Wilkinson and H. Wollis. (2002)

No. 61 Inventory of western spiderwort (Tradescantia occidentalis) in Alberta: 2002, by S. Peters. (2003)

No. 62 Bullsnakes (Pituophis catenifer sayi) in Alberta: literature review and data compilation, by K.J. Kissner and J. Nicholson. (2003)

No. 63 Distribution of Ord's kangaroo rats in southeastern Alberta, by D.L. Gummer and S.E. Robertson. (2003)

No. 64 Lethbridge prairie rattlesnake conservation project: 2002/2003 progress report, by R.D. Ernst. (2003)

No. 65 Short-horned lizard (Phrynosoma hernandesi hernandesi) populations in Alberta - 2002 survey results, by J.D. James. (2003)

No. 66 Inventory and monitoring protocol for naturally occurring western blue flag (Iris missouriensis) in Alberta, by R.D. Ernst. (2003)

No. 67 The use of call playbacks for censusing loggerhead shrikes in southern Alberta, by D.R.C. Prescott. (2003)

No. 68 Survey of bats in northeastern Alberta, by A. Hubbs and T. Schowalter. (2003)

No. 69 Survey protocol for the Richardson's ground squirrel, by B.A. Downey. (2003)

No. 70 Population estimates and a survey protocol for ferruginous hawks in Alberta, by B.N. Taylor. (2003)

No. 71 Testing methods for detecting wolverine, by G. Mowat, C. Kyle and D. Paetkau. (2003)

No. 72 A multi-species conservation strategy for species at risk in the Milk River basin: year 1 progress report, by R.W. Quinlan, B.A. Downey, B.N. Taylor, P.F. Jones and T.B. Clayton. (2003) 
No. 73 Long-toed salamander (Ambystoma macrodactylum) conservation in the Alberta foothills: 2002 field summary report, by L. Wilkinson and S. Hanus. (2003)

No. 74 Researching Amphibian Numbers in Alberta (RANA): 2002 provincial summary, by L. Wilkinson and S. Hanus. (2003)

No. 75 Distribution and habitat associations of the long-toed salamander (Ambystoma macrodactylum) in the Oldman River drainage, by K. Pearson. (2003)

No. 76 Prairie rattlesnake (Crotalus viridis) hibernacula: monitoring history in Alberta 1987-2002, by K.J. Kissner and J. Nicholson. (2003)

No. 77 Alberta species at risk program and projects 2002-2003, by Alberta Sustainable Resource Development, Fish and Wildlife Division. (2003)

No. 78 Northern leopard frog reintroduction: Year 4 (2002), by K. Kendell. (2003)

No. 79 Magrath Northern Leopard Frog reintroduction project - Year 1 Progress Report, by K.A. Romanchuck. (2003)

No. 80 Conservation overview of butterflies in the Southern Headwaters at Risk Project (SHARP) Area, by N. Kondla. (2004)

No. 81 Lethbridge rattlesnake conservation project: 2003 Progress Report, by R. Ernst. (2004)

No. 82 Shortjaw cisco species at risk assessment 2001, by M. Steinhilber. (2004)

No. 83 Researching Amphibian Numbers in Alberta (RANA): 2003 provincial summary, by L. Wilkinson and K. Kempin. (2004)

No. 84 Methods for controlling depredation on piping plovers in Alberta: A Literature Review and Synthesis, by R. Schmelzeisen, D.R.C. Prescott and L. Engley. (2004)

No. 85 Western blue flag conservation program: 3-year summary report, by K.A. Romanchuk, R.D. Ernst, and R.W Quinlan (2004)

No. 86 MULTISAR: The Milk River basin habitat suitability models for selected wildlife management species, by B. A. Downey, B. L. Downey, R. W. Quinlan, O. Castelli, V. Remesz and P. F. Jones (eds.). (2004)

No. 87 MULTISAR: The Milk River basin, a multi-species conservation strategy for species at risk: year 2-progress report, by R.W. Quinlan, B. A. Downey, B. L. Downey, and P. F. Jones. (2004)

No. 88 Survey of colonial nesting birds and lakeshore habitats in northeast Alberta, by C. Found and A. Hubbs. (2004)

No. 89 The southern headwaters at risk project: A multi-species conservation strategy for the headwaters of the Oldman River. Volume 1: Introduction and natural processes, by F. Blouin. (2004)

No. 90 The southern headwaters at risk project: A multi-species conservation strategy for the headwaters of the Oldman River. Volume 2: Species selection and habitat suitability models. Alberta Sustainable Resource Development, Fish and Wildlife Division, Alberta Species at Risk Report No. 90, Edmonton, AB, by F. Blouin, B.N.Taylor, and R.W. Quinlan (eds). (2004)

No. 91 Distribution, abundance and habitat selection of northern pygmy and barred owls along the eastern slopes of the Alberta Rocky Mountains, by M. D. Piorecky and D. R. C. Prescott. (2004)

No. 92 Survey of aquatic gastropods in the Central Parkland Subregion of Alberta, by D. R. C. Prescott and M. M. Curteanu. (2004) 



NATIONAL LIBRARY OF CANADA

Bibliothèque nationale du Canada

33286530277546 